\begin{tabular}{|c|c|c|}
\hline Beitr. Ent. & Keltern & ISSN 0005-805X \\
\hline $\mathbf{6 0}(2010) 2$ & S. $363-426$ & 20.12 .2010 \\
\hline
\end{tabular}

\title{
The Neotropical species of the genus Osorius GuÉRIN-MENEVILLE, 1829 with remarks to the Neotropical Osoriid complex
}

\section{(Coleoptera: Staphylinidae: Osoriinae)}

With 40 figures and 3 maps

\section{ULRICH IRMLER}

\begin{abstract}
Summary
As a result of review studies on the Neotropical Osorius complex a key to the Neotropical genera of the tribe Osoriini is provided, which includes the new genus Antillosorius with 18 described species from the West Indies. New records of the two species Ouloglene barberi Notman, 1925 and Oryssoma schwarzi Notman, 1925 are given. In total, 35 species of the genus Osorius are described or redescribed. Eight new species have been found in the collections studied. These are: O. verhaaghi, O.paganus, O. venezuelanus, O. pusillus, $O$. ashei, O. tschirnhausi, O.guianensis, O.continentalus. The ecology of the species and zoogeographic distributions are discussed.
\end{abstract}

\section{Keywords}

Staphylinidae, Osoriinae, Neotropics, new species, new genus, new descriptions, new records, key to genera, key to species, distribution

\section{Zusammenfassung}

Im Zuge einer Revision des neotropischen Osorius Komplexes wurde ein Bestimmungsschlüssel zu den neotropischen Gattungen des Tribus Osoriini erstellt, der die neue Gattung Antillosorius enthält, die mit 18 bereits beschriebenen Arten der Westindischen Inseln vertreten ist. Neue Funddaten der beiden Arten Ouloglene barberi Notman, 1925 und Oryssoma schwarzi NotMan, 1925 werden aufgelistet. Insgesamt werden 35 Arten der Gattung Osorius beschrieben oder neu beschrieben. Acht neue Arten wurden in den untersuchten Sammlungen gefunden. Diese sind: O. verhaaghi, O. paganus, O. venezuelanus, O. pusillus, O. ashei, O. tschirnhausi, O. guianensis, O. continentalus. Es wird die Ökologie der Arten und die zoogeographische Verbreitung diskutiert.

\section{Schlüsselbegriffe}

Staphylinidae, Osoriinae, Neotropis, neue Arten, neue Gattung, neue Beschreibungen, neue Funddaten, Gattungsschlüssel, Artschlüssel, Verbreitung 


\section{Introduction}

The genus Osorius was first mentioned by Guérin-Meneville (1829) in the 'Iconographie du règne animal de $\mathrm{G}$. Cuvier' based on the drawing of a Brazilian species. According to the catalogue of Herman (2001), the genus Osorius presently totals 98 species in the Neotropical region. However, the Osorius complex (genera of Osoriini with spines at outer edge of protibia) was split into different genera by FAGEL (1959) on the basis of the African species. He differentiated the following genera mainly by the development of the protibia, the elytra and the aedeagus: Afrosorius, Allosorius, Neosorius, Osoriellus, and Osoriocanthus. In an earlier publication, FageL (1958) separated the Neotropical Osorius from the similar African Afrosorius mainly by the absence of the spiral endophallus of the aedeagus. Since Bernhauer (1908) described Anancosorius from Brazil and Notman (1925) the two genera Ouloglene and Oryssoma from Guatemala, seven genera could be expected in the Neotropical fauna.

Although generic keys are provided by Blackwelder (1943) and Notman (1925), a modern generic assignment of the described Neotropical Osorius species is missing. Thus, this study will 1) provide a generic key to the Neotropical osoriid complex, 2) redescription of the known Osorius species, because many species were described insufficiently and on the basis of only one female specimen, and 3) describe new Osorius species from the Neotropical region. Furthermore, new records are listed with regards to the two species Ouloglene barberi, Oryssoma schwarzi, and numerous Osorius species.

\section{Material and methods}

The material studied in this investigation is presently deposited in the following public museums and private collections:

$\begin{array}{ll}\text { AMNH } & \text { American Museum of Natural History, New York, U.S.A. } \\ \text { BMNH } & \text { The Natural History Museum, London, United Kingdom } \\ \text { FMNH } & \text { Field Museum of Natural History, Chicago, U.S.A. } \\ \text { IRSNB } & \text { Institut Royal des Sciences Naturelles de Belgique, Brussels, Belgium } \\ \text { KU } & \text { University of Kansas, Museum of Natural History, Lawrence, Kansas, U.S.A. } \\ \text { MS } & \text { Swedish Museum of Natural History, Stockholm } \\ \text { NMP } & \text { National Museum, Prague, Czech Republic } \\ \text { ZMHU } & \text { Zoologisches Museum der Humboldt-Universität, Berlin, Germany } \\ \text { ZMUK } & \text { Zoological Museum, Natural History Museum of Denmark, Copenhagen } \\ \text { ZSM } & \text { Zoologische Staatssammlung, Munich, Germany } \\ \text { UNAM } & \text { Museo de Zoología, Facultad de Ciencias, Mineral de la Reforma, Mexico } \\ \text { AC } & \text { private collection of V. Assing, Hannover, Germany } \\ \text { CC } & \text { Coleção entomologica Universidade do Curitiba, Curitiba, Paraná } \\ \text { JC } & \text { private collection of J. Janák } \\ \text { RC } & \text { private collection of G. de Rougemont, London } \\ \text { UIC } & \text { private collection of author, Plön, Germany }\end{array}$

The photographs were taken using a Makroskop M 420 (Wild, Herbrugg) in combination with a digital camera (Nikon D100). Maps were generated by ArcView Gis 3.2 (ESRI 1999). Length was measured in the middle of tagmata: head from clypeus to posterior edge, pronotum from anterior to posterior edge along midline, elytra from anterior edge at shoulders to posterior edge; width at the widest part of tagmata (head width includes eyes). In the measurement of total length, the abdominal inter-segmental space is subtracted. From the total of 98 species described in the genus 
Osorius from the Neotropical region 5 species have not been studied, because the types are lost or the museum or collection of deposition is unknown. The following species were not studied: O. parvulus Scriba, 1855, O. planifrons LeCompte, 1877, O. pygmaeus Laporte, 1835, O. frater Lynch, 1884, O. cylindricus Latreille, 1832, and O. canaliculatus Solsky, 1870.

\section{The generic differentiation of the Neotropical osoriid complex with description of a new genus and a key to genera}

Osorius brasiliensis is fixed as type species of the genus Osorius by subsequent monotypy (Blackwelder, 1952). The generic name Osorius was first mentioned by Guérin-Meneville (1829) for a species imaged onto plate IX fig. 11 in the 'Iconographie du Règne Animal'. Later, a detailed description of the imaged species followed by LaTreILLE (1932) in which it was named as $O$. brasiliensis Latreille, 1932 with a remark on O. tardus Dejéan. It is necessary to consider the description by LATREILle (1832) to understand the confusion concerning O. brasiliensis. LATREILLE (1832) wrote (translated from French):

'Very black, shiny, with antennae dark black and tarsi light brown; a strong obtuse tooth on each side of the front edge of the head and one tooth at the inner side of the right mandible; head and pronotum even; the last part finely margined at its posterior edge. - Length $9-13 \mathrm{~mm}$.

The Museum d'histoire naturelle owes a specimen, among many other interesting insects, to the generosity of M. Adolphe de Lattre, an excellent painter that was delivered to him for his studies on animals during his stay in Brazil. I am also very obliged to him for the same species that is now represented by a small specimen figured by $\mathrm{M}$. Guérin.'

Later, Guérin-Meneville (1844) referred to figure 11 of plate IX with the following comment: 'Location - Rio de Janeiro. Latreille has given a description of that species in the Annales du Mueum, t.1, p. 86. M. Delaporte (Etudes entomologiques p. 131) remarks that it seems not to differ from $O$. ater of Perty, except by the absence of the teeth of the head and if this is a sexually specific character this insect might be a female of $O$. ater of Perty.'

According to personal information from the curator of the Muséum national d'histoire naturelle, France, Paris, Dr. T. Azadeh, the type specimen of O. brasiliensis or O. tardus is not deposited in the museum. This is in accordance with the references in HoRn \& KAHLE (1935), which states that the Staphylinidae of the Guérin-Meneville collection have been deposited via Sharp in the British Natural History Museum, London. A comprehensive survey of the material of Neotropical Osorius species deposited in the Natural History Museum, London, found three specimens labelled as $O$. brasiliensis or $O$. tardus which might have originated from the Guérin-Meneveille collection and were additionally labelled as Sharp's collection. Because no specimen from the collection was labelled with location Rio de Janeiro, a definite assignment was impossible. Two specimens are labelled with location Brazil; one was later correctly identified as $O$. ater, one as $O$. brasiliensis. It cannot be excluded that the specimen labelled as Osorius brasiliensis, but later identified as $O$. ater is the original $O$. brasiliensis, since Latreille mentioned strong obtuse teeth at the front edge of the clypeus in his description of $O$. brasiliensis. Indeed, $O$. ater is typically specified by strong teeth at the front edge of the clypeus, but variation is very large. The $O$. ater specimen labelled as $O$. brasiliensis is characterised by weakly developed teeth, though they are large enough to be an $O$. ater, for sure. Regarding the uncertainty of the type designation and in order to avoid synonymies, I selected the second specimen, although a female, to designate a neotype of $O$. brasiliensis. 
During his studies on African Osorius species, FAGEL (1958) separated the genus Afrosorius mainly by the development of a spiral endophallus which is absent in the Neotropical Osorius species. Later, FAGEL (1959) provided a generic key of the osoriid complex based on his studies of African species. Among the extensive collections of the KU, the AMNH, the BNHM, my own and several other private collections there was no Neotropical species found with a spiral endophallus. Thus, the genus Afrosorius FAGEL, 1958, seems to be absent from South- and Central America. This also seems to be true for the genus Allosorius FAGEL, 1959, which is characterised by an asymmetric development of the clypeus. According to FAGEL's (1959) descriptions, in the studied collections 1 female specimen might be placed to Osoriocanthus Fagel, 1959 others specimens to Neosorius Fagel, 1959. Both genera, therefore, occur in the Neotropical fauna. At least two genera remained and account for the major amount of Neotropical species: Osorius and Osoriellus Fagel, 1959. According to FageL (1959), Osoriellus was mainly separated from Afrosorius/Osorius by the development of the protibia. Species of the genus Osorius are large and develop a dentate lateral edge of protibia with spines on the back side among setae. In the smaller Osoriellus the lateral edge of protibia is not dentate and the back side of the protibia is only setose. However, in the Neotropical species with only setose back side of protibia, species exist with distinctly dentate lateral edge. Several small species, e.g. Osorius eggersi Bernhauer, 1904, have a smooth lateral margin and spines without denticulation, which corresponds with the African Osoriellus. The remaining species show a high variation of dentation.

A comparative study of the pronotum showed that the Neotropical Osorius (Fig. 36 A-D, 37 A-D) and the related African Afrosorius have a flat margin widened to posterior angles. In contrast, the Neotropical and African Neosorius and Osoriellus studied have a narrow pronotal margin equal in width throughout the total length (Fig. 39 B). A group of species mainly occurring in the West Indies are characterised by a setose back side and dentate lateral edge of protibia, but with widened lateral margin of pronotum such as in Osorius. Overall, the Neotropical species with setose back side of the protibia are very heterogeneous and certainly cannot be placed in one genus. As they form the major part of the currently known species in the Neotropical Osorius complex, a more detailed study of these species is necessary to compile a final generic key for the Neotropics. A preliminary key is provided here for the tribe Osoriini, including the known genera at present found in the studied collections. Thus, genera are included that are not described from the Neotropics, but were indeed found in the studied collections from Central and South America. Only the West Indian species characterised as mentioned above are placed under the new genus Antillosorius.

\section{Antillosorius gen. n.}

\section{Type species:}

Osorius solutator DARLINGTON, 1937 is fixed here as generic type of Antillosorius.

\section{Description:}

Five to $15 \mathrm{~mm}$ large species of dark colour or with reddish elytra or abdomen in some species; head with eyes slightly or not prominent; clypeus distinctly narrowed from base of antennae to apical edge and with front edge of clypeus crenulate or not narrowed and a pair of prominent teeth; punctation of head varying in density and distinctness and with few to numerous granular setiferous punctures on a supraocular space; antennae angulate; with long first antennomere and following antennomeres not increasing in width; antennomeres 4 to 10 nearly quadrate; pronotum distinctly emarginate in front of posterior angles (Fig. 39 A); margin narrow at anterior angles and distad wider to posterior angles; elytra sparsely punctate and with indistinct to distinct ground sculpture; abdomen with segment III to VII increasing in width; setiferous punctation absent or 
present; protibia with spines at outer edge that insert in short or moderately long teeth; posterior side of protibia with setiferous punctures, but without spines; aedeagus asymmetric, similar as in Osoriellus.

\section{Diagnosis:}

Most species are characterised by the crenulate front edge of the clypeus in contrast to all other genera of Osoriini, but instead of that shape clypeus may have a pair of prominent teeth like in Osorius ater, e.g. in Antillosorius hubbardi (Notman, 1925). They are differentiated from Neosorius FAGEL, 1959 by the absence of spines on the posterior side of the protibia and the development of the lateral margin of pronotum that is widened in the posterior half as in Osorius. They can be distinguished from Osoriellus by the usually larger size, the development of the lateral margin of the pronotum and the outer spines of the protibia inserting on more or less long teeth. As in Osoriellus FaGel, 1959 the posterior side of protibia is only setose. Antillosorius resembles Osorius in the development of the pronotal lateral margin, but differs in the development of the protibia, that is only setose, whereas it is mixed with spines between the setae in Osorius.

In point of fact, 18 species are known from the West Indies. BlaCKWELDER (1943) provides a key to the species under numbers 1 to 17 in his key to West Indian Osorius and $A$. hubbardi (Notman, 1925) under number 19. Thus, new combinations are proposed for the following species:

Antillosorius biarmatus (Darlington, 1927) comb. nov.

A. buscki (Notman, 1925) comb. nov.

A. cautis (Darlington, 1937) comb. nov.

A. crenulifrons (Notman, 1925) comb. nov.

A. cubensis (BlaCKWELder, 1943) comb. nov.

A. daemon (Darlington, 1937) comb. nov.

A. darlingtoni (Blackwelder, 1943) comb. nov.

A. fratellus (DARLINGTON, 1937) comb. nov.

A. hirtilabris (Bernhauer, 1915) comb. nov.

A. hubbardi (Notman, 1925) comb. nov.

A. manni (Notman (1925) comb. nov.

A. mediocris (Darlington, 1937) comb. nov.

A. oriente (BACKWELDER, 1943) comb. nov.

A. regulus (DARLINGTON, 1937) comb. nov.

A. salutator (DARLINGTON, 1937) comb. nov.

A. socors (Darlington, 1937) comb. nov.

A. strictus (BLACKWELDER, 1943) comb. nov.

A. turquinus (BlaCKWElder, 1943) comb. nov.

\section{Key to genera of tribe Osoriini}

1. Protibia slightly broader, mesotibia not broader than metatibia, protibia and mesotibia with few fine spines at outer edge, antennae not angulate. 2

Protibia and mesotibia distinctly broader than metatibia and with distinct spines, antennae angulate. 
2. Pronotum in front of posterior edge deeply emarginate. ........................................... 3

- Pronotum in front of posterior edge not emarginate. .............................................. 5

3. Eyes small, only few omatidia present, elytra short, twice as wide as long.

Mimotrochus IRMLER, 1987

Eyes of normal size, usually distinctly prominent, elytra longer, as wide as or longer than wide.

4. Pronotum laterally margined including the emargination in front of posterior angles, posterior angles with depression. Mimogonus Fauvel, 1903

Emargination of pronotum not margined. Mimogonia CoIffait, 1978

5. Clypeus emarginate; head and pronotum with broad margin.

Craspedus Bernhauer, 1908

Clypeus not emarginate; head not margined, pronotum with fine margin.

Holotrochus ERICHSON, 1839

6. Small species of 1.8 to $2.2 \mathrm{~mm}$ length, legs with three tarsomeres and aedeagus with paramera.

Usually larger species, longer than $2.5 \mathrm{~mm}$, legs with five tarsomeres and aedeagus without paramera.

7. Last antennomere wider than long, eyes extremely reduced, only one omatid present. .... Ouloglene Notman, 1925

Last antennomeres longer than wide, eyes normally developed.

Oryssoma Notman, 1925

8. Pronotum without lateral margin, clypeus with two long acute teeth, head and pronotum dull, body totally covered with setae. Anancosorius Bernhauer, 1908

- $\quad$ Pronotum with lateral margin, clypeal teeth, if present, broad or obtuse. 9

9. Shoulders rectangular with prominent tooth Osoriocanthus Fagel, 1959 Shoulders obtuse, not dentate

10. Pronotum emarginate in front of posterior angles, in some species only extremely slightly, lateral margin of pronotum widened to posterior angles (Fig. 36 A-D, 37 A-D, 39 A). ...

Margin of pronotum equal in width (Fig. 39 B), sides continuously narrowed from anterior to posterior angles.

11. Posterior side of protibia with setae and spines. Osorius Guérin-MÉnEVILle, 1829 Posterior side of protibia only setose, without short and thick spines. Antillosorius n. gen.

12. Posterior side of protibia only setose, without thick spines. Osoriellus Fagel, 1959 Posterior side of protibia with spines and setae. Neosorius FAGEL, 1959 


\title{
New records of Ouloglene barberi and Oryssoma schwarzi
}

\section{Ouloglene barberi NotMAN 1925: 4}

\begin{abstract}
Material examined:
Mexico: Chiapas, Palenque ( $\left.91^{\circ} 58^{\prime} \mathrm{W}, 17^{\circ} 29^{\prime} \mathrm{N}\right)$, ruines, stump litter, 5 specimens, 6.4.1974, leg. C. Alteri, (NW); Palenque, $100 \mathrm{~m}$ elevation, 03.04.1974, leg. C. Alteri (AMNH); ruines, litter, 2 specimens, 28. - 29.03.1974, leg. C. Alteri (AMNH, UIC); Guatemala: Alta Vera Paz, Trece Aguas (89 $45^{\prime}$ W, $15^{\circ} 24^{\prime}$ N), Cacao, 1 specimen, 18.04.1906, leg. E.A. Schwarz (holotype,

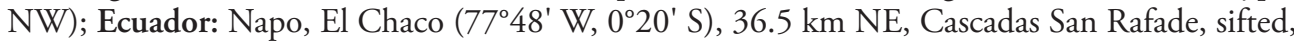
3 specimens, 29.11.2006, leg. Fikácek (NMP); Puerto Napo (7743' W, 0102' S), $6.9 \mathrm{~km} \mathrm{E,}$ primary forest with sparse understory, shady, leaf litter, rotten branches along trail, sifted, 1 specimen, 24.11.2006, leg. Fikácek (NMP); Peru: Huanuco, Panguana (7456' W, 9³7' S), 1 specimen, 16.6.1984, leg. M. Verhaagh (UIC); Brazil: Amazonas, Manaus (600' W, $\left.3^{\circ} 07^{\prime} \mathrm{N}\right)$, INPA/Smithsonian Res, Terra firme forest, leaf litter, Winkler sample, 1 specimen, 01.1994, leg. R. Didham (BMNH).
\end{abstract}

\section{Oryssoma schwarzi NoTMAN 1925: 4}

\section{Material examined:}

Guatemala: Alta Vera Paz, Trece Aguas (8945' W, 15²4' N), Cacao, 1 specimen, 18.4.1906,

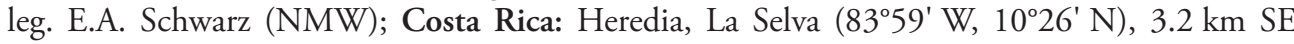
P. Viejo, flight intercept trap, 1 specimen, 14.2.1992, 1 specimen, 9.2.1992, leg. W. Bell (KU);

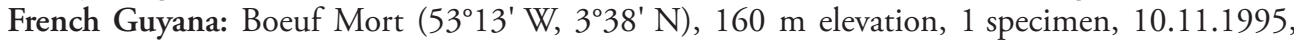
leg. L. Herman (AMNH); Saül $\left(53^{\circ} 12^{\prime} \mathrm{W}, 3^{\circ} 37^{\prime} \mathrm{N}\right)$, Les Eaux claires, leaf litter near stream, 5 specimens, 5.10.1995, leg. L. Herman (AMNH); Venezuela: Carabobo, Bejuma (68 25' W, $\left.10^{\circ} 17^{\prime} \mathrm{N}\right)$, Via Palmichal, 1 specimen, 22.11.2005, leg. L. Brachat (AC); Brazil: Bahia, Urucuca $\left(39^{\circ} 03^{\prime} 43 \mathrm{~W}, 14^{\circ} 25^{\prime} 17 \mathrm{~S}\right)$, primary Atlantic forest, 1 specimen, 28.01.1995, leg. D. Agosti (AMNH); Ecuador: Napo, Tena (7749' W, 059' S), 33 km N Tena, litter near stream, 1 specimen, 4.11.1988, leg. L. Herman (AMNH); Puerto Napo, 21 km E., Jatun Biol. Sta. (77³6' W, $1^{\circ} 03 \mathrm{~S}$ ), lowland rain forest, flight intercept trap, 1 specimen, 9.7.1994, leg. F. Genier (KU); Puerto Napo $\left(77^{\circ} 43^{\prime} \mathrm{W}, 1^{\circ} 02^{\prime} \mathrm{S}\right), 6.9 \mathrm{~km}$ E, primary forest with sparse understory, shady, leaf litter, rotten branches along trail, sifted, 4 species, 24.11.2006, leg. Fikácek (NMP); Archidona (7748' W, 054' S), $4.1 \mathrm{~km} \mathrm{W,} \mathrm{dense} \mathrm{secondary} \mathrm{forest} \mathrm{margin,} \mathrm{nr.} \mathrm{banks} \mathrm{of} \mathrm{muddy} \mathrm{stream,} \mathrm{wet} \mathrm{leaf}$ litter, sifted, 5 specimens, 19.11.2006, leg. Fikácek (NMP, UIC); Pastaza, Santa Clara $\left(77^{\circ} 52^{\prime}\right.$ W, $\left.01^{\circ} 18^{\prime}\right)$, lowland rain forest, with very sparse understory and numerous young trees, leaf litter, sifted, 2 specimens, 15.11.2006, leg. Fikácek (NMP); Peru: Huanuco, Panguana $\left(74^{\circ} 56^{\prime} \mathrm{W}\right.$, $9^{\circ} 37^{\prime}$ S), tropical rain forest, pitfall trap \#PWa 6, 1 specimen, 17.03.1984, leg. M. Verhaagh

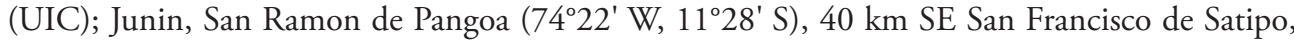
10 specimens, 1.6.1972, leg. R.T. Schuh (AMNH, UIC). 


\section{Descriptions of Osorius species including new species and a key to species}

\section{Redescription of the genus Osorius GuÉRIN-MeneVILLE, 1829}

\section{Type species:}

Osorius brasiliensis GuÉRIN-Meneville, 1829.

\section{Description:}

Six to $17.5 \mathrm{~mm}$ large species of dark colour; head with eyes distinctly or not prominent; clypeus with symmetric acute or obtuse teeth at outer angles; punctation of head varying in density and distinctness and with few to numerous granular setiferous punctures on a supraocular space; antennae angulate; with long first antennomere; pronotum slightly or distinctly emarginate in front of posterior angles (Fig. 36 A-D, 37 A-D); margin narrow at anterior angles and distad widened to posterior angles; elytra with distinct, mostly coriaceous ground sculpture; abdomen with segments III to VII increasing in width; setiferous punctation absent or present; protibia with spines at outer edge that insert in short or moderately long teeth; posterior side of protibia with setae and with spines; aedeagus symmetric or asymmetric and without inner sclerotic structures.

\section{Diagnosis:}

The genus has distinct teeth with spines at outer edge of protibia and spines on posterior side of protibia among pubescence as found in Allosorius Fagel 1959, Afrosorius Fagel, 1958, and Neosorius Fagel, 1959. It is differentiated from Allosorius Fagel 1959 by the symmetric teeth of clypeus (Allosorius Fagel, 1959 with asymmetric teeth), from Afrosorius Fagel 1958 by the absence of inner sclerotic structures of the aedeagus, and from Neosorius FAGEL, 1959 by the laterally emarginate pronotum in front of posterior angles and the distad widened lateral margin.

\section{Key to the Neotropical species of Osorius}

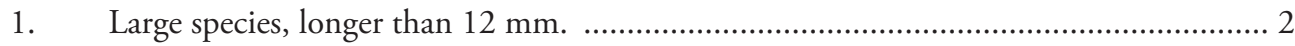

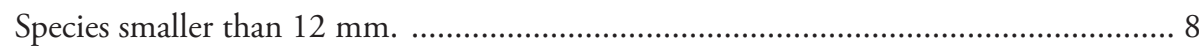

2. Front angles of clypeus long and acute (Fig. 1d). .......................... O. ater Perty, 1830

Front angles of clypeus obtusely prominent (Fig. 23d). ........................................... 3

3. With numerous supraocular striae and granulate punctures (Fig. 2e). ........................ 4

Without or with only few supraocular striae, but with numerous postocular striae (Fig. 4e).

4 Apical part of aedeagus long and acuminate (Fig. 2c). O. stipes SHARP, 1876 Apical part of aedeagus shorter and obtuse (Fig. 3c). O. alternans BERNHAUER, 1920

5 Surface of elytra with dense coriaceous ground sculpture, punctation within in the coriaceous ground sculpture not visible (Fig. 39 A).

Surface of elytra with sparse coriaceous ground sculpture, shiny, nearly polished, punctation on all parts clearly visible (Fig. 39 B). 
6. Larger species, at least $14 \mathrm{~mm}$ long, clypeus with central prominence, microsculpture of pronotum weak, surface nearly polished.

O. canaliculatus Solsky, 1870

- Smaller species of about $13 \mathrm{~mm}$, clypeus without central prominence, microsculpture of pronotum distinct, surface slightly shiny.

O. columbinus BernHauer, 1920

7. Pronotum without depressions in posterior angles. ...... O. intermedius Erichson, 1840

Pronotum with indistinct depressions in posterior angles. .... O. brasiliensis GuÉRIN, 1829

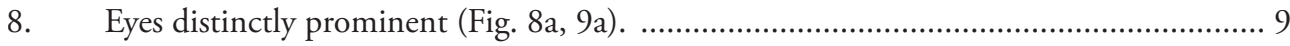

Eyes not or only slightly prominent (Fig. 10a). ..................................................... 10

9. Larger, $8.0 \mathrm{~mm}$ long, $3^{\text {rd }}$ antennomere twice as long as $2^{\text {nd }}$.......... O. boops SHARP, 1887

Smaller, $7.0 \mathrm{~mm}$ long, $3^{\text {rd }}$ antennomere not longer than $2^{\text {nd }} . \ldots . .$. O. affinis SHARP, 1876

10. Small, not longer than $8.0 \mathrm{~mm}$, pronotum relatively long, length: width relationship between 0.87 and 1.1 .

Larger than $8.5 \mathrm{~mm}$, pronotum wider, length: width relationship $0.74-0.87$.

11. Pronotum with dense and deep microsculpture, surface matte or slightly shiny (Fig. 38 D).

Pronotum with weak microsculpture and micro-punctation (Fig. 38 C).

O. dentatus Bernhauer, 1920

12. Punctation on pronotum sparse and fine, distance between punctures at least three times wider than diameter of punctures (Fig. 38 D).

Punctation on pronotum denser and larger, distance between punctures two times wider than diameter of punctures (Fig. $38 \mathrm{E}$ ).

13. Microsculpture of pronotum dense, but not deep, surface slightly shiny, head with postocular striae. O. costaricensis BERNHAUER, 1942

Microsculpture of pronotum dense and deep, surface matte, head without postocular striae.

14. Side of pronotum nearly parallel (Fig. $36 \mathrm{~A}$ ), posterior edge nearly as long as anterior edge, shoulders nearly rectangular. O. verhaaghi sp. n.

Pronotum slightly, but distinctly narrowed to posterior angels (Fig. 36 B), anterior edge about 1.1 times longer than posterior edge, shoulders obtuse, smoothly rounded.

O. paganus sp. $\mathrm{n}$.

15. Clypeus close to the outer obtuse prominence with an additional acute tooth on each side (Fig. 15d). O. venezuelanus sp. $\mathrm{n}$. Clypeus only with an outer prominence on each side. 16

16. Smaller, $6.0 \mathrm{~mm}$; anterior angles of pronotum tooth-like prominent (Fig. $36 \mathrm{D}$ ), pronotum less narrowed to posterior angles, anterior edge only 1.1 times wider than posterior edge. O. pusillus sp. n.

Larger, $7.4-8.0 \mathrm{~mm}$ long.

17. Punctation of pronotum deeper and denser, anterior angles not prominent, larger, $7.8-8.0 \mathrm{~mm}$. O. laevicollis Bernhauer, 1908 
Punctation of pronotum slightly sparser and finer, anterior angles prominent, smaller, $7.5 \mathrm{~mm}$. O. sublaevis BERNHAUER, 1920

18. Sides of pronotum in front of posterior angles deeply emarginate (Fig. 19a). O. sinuatocollis BeRnHAUER, 1920

Sides of pronotum only slightly emarginate in front of posterior angles (Fig. 20a). ..... 19

19. Pronotum with micro-punctation between the normal larger punctures (Fig. 38 F). ... 20

Pronotum without micro-punctation between the normal larger punctures. .............. 24

20. Pronotum without microsculpture, surface polished. …......................................... 21

Pronotum with weak microsculpture, surface shiny, but not polished. ...................... 23

21. With numerous supraocular and postocular striae, linear furrow in pronotal midline extending to anterior half (Fig. 21a, 22a). 22

With few supraocular striae, linear furrow on pronotal midline only in posterior half. .... O. ashei sp. n.

22. Pronotum with irregular punctation and an indistinct transverse depression in the middle. O. laevigatulus SCHUBERT, 1911

Pronotum regularly punctate and without transverse depression.

O. wasmanni BERNHAUER, 1920

23. Head with numerous granulate punctures and supraocular and postocular striae. O. peruvianus Bernhauer, 1908

Head without granulate punctures and supraocular striae, only with few postocular striae. O. integer SHARP, 1876

24. Clypeus with thick obtuse lateral prominence and a long acute tooth, separated by a broad and deep emargination (Fig. 25d). O. tschirnhausi sp. n. Clypeus only with lateral obtuse prominences. 25

25. Pronotum with weak microsculpture, surface shiny, but not polished. 26 Pronotum with dense and distinct microsculpture, surface matte or only slightly shiny. .. 27

26. Clypeus with numerous granulate punctures (Fig. 39 C), except on a small space in the middle. O. granulatus Bernhauer, 1920

Clypeus without granulate punctures. O. guianensis sp. $\mathrm{n}$.

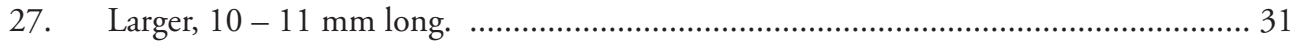

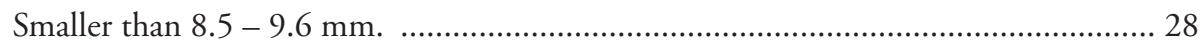

28. Pronotum very finely and sparsely punctate, microsculpture deep and dense, surface matte (Fig. 38 G). .............................................................................. O. dubius Sharp, 1887

Punctation of pronotum deeper and denser, microsculpture weaker, surface slightly shiny $(38 \mathrm{H})$.

29. Pronotum more or less triangular (Fig. 28a), with dense punctation, elytra with deep coriaceous ground sculpture, apex of aedeagus thick and obtuse (Fig. 28c). 
Pronotum with slight and short emargination in front of posterior angles, punctation sparser, apex of aedeagus acute.

30. Elytra dark brown with weak ground sculpture, punctures distinct, punctation of pronotum sparser, distance between punctures on average wider than diameter of punctures, surface matter, apex of aedeagus short and acute (Fig. 29c). .............. O. piceus Erichson, 1840 Elytra black with deeper ground sculpture, punctures indistinct, punctation of pronotum denser (Fig. $37 \mathrm{C}$ ), distance between punctures on average as wide as diameter of punctures, apex of aedeagus long and acute (Fig. 30c).

O. continentalus sp. n.

31. Microsculpture of pronotum dense and deep, surface matte, punctation irregular and sparser, distance between punctures wider than diameter of punctures, aedeagus with obtuse apex (Fig. 31c). O. sahlbergi Bernhauer, 1920

Microsculpture of pronotum weaker, surface slightly shiny, punctation denser, distance between punctures shorter than diameter of punctures, aedeagus with acute apex. ..... 32

32. Pronotum strongly narrowed from anterior to posterior angles, anterior edge more than 1.3 times wider than posterior edge.

- $\quad$ Pronotum less narrowed from anterior to posterior angles, anterior edge less than 1.3 times wider than posterior edge.

33. Punctation of pronotum coarse and dense, distance between punctures on average only half as wide as diameter of punctures (Fig. $38 \mathrm{H}$ ), with deep longitudinal depression (Fig. 32a).

O. confusus Notman, 1925

Punctation of pronotum slightly weaker, but as dense, on average only half as wide as diameter of punctures, without longitudinal depression (Fig. 33a).

O. puncticeps SHARP, 1887

34. Punctation of pronotum sparser and finer, distance between punctures wider than diameter of punctures, microsculpture weaker. O. propinquus BernHAUER, 1920

- Punctation of pronotum denser and coarser, distance between punctures shorter than diameter of punctures, microsculpture deeper, surface matter. O. nitens SHARP, 1876

\section{Description of the Osorius species}

\section{Osorius affinis SHARP, 1876: 385 (Figs 9 a-b)}

\section{Type material examined:}

Brazil: Amazonas: São Paulo de Olivença, 1 female without further data (holotype, BMNH).

\section{Diagnosis:}

O. affinis is one of the smallest Osorius species and, in this respect, similar to O. costaricensis. It can be distinguished from $O$. costaricensis by the large prominent eyes. It can be separated from $O$. boops that is also characterised by prominent eyes by the smaller size. Unfortunately, only the female holotype could be studied. The species was not found in any other collection.

\section{Description:}

Length: $7.0 \mathrm{~mm}$. Colour: black, legs and antennae dark brown. 
Head: $0.80 \mathrm{~mm}$ long, $1.25 \mathrm{~mm}$ wide; eyes slightly prominent and 0.5 times longer than temples; with moderately dense punctation; punctures denser near neck than on disc and clypeus; on average, distance between punctures as wide as or slightly smaller than diameter of punctures; surface with distinctly isodiametric microsculpture; slightly shiny; laterad with numerous supraocular striae and several supraocular granular setiferous punctures.

Antennae with $2^{\text {nd }}$ antennomere globular and $3^{\text {rd }}$ one conical; both antennomeres equal in length; antennomeres 4 to 11 increasing in width, but still penultimate antennomeres quadrate.

Pronotum: $1.35 \mathrm{~mm}$ long, $1.45 \mathrm{~mm}$ wide; widest at anterior edge; continuously narrowed to posterior edge; shortly in front of posterior angles with weak emargination; lateral margin small, not visible at anterior angles in dorsal aspect, scarcely widened to posterior angles; disc with moderately dense longitudinal punctation; distance between punctures on average as wide as or distinctly smaller than diameter of punctures; a midline without punctures in posterior half; surface with deep isodiametric microsculpture, microsculpture deeper than on head, scarcely shiny.

Elytra: $1.50 \mathrm{~mm}$ long, $1.45 \mathrm{~mm}$ wide; punctation deep and distinct; with deep coriaceous ground sculpture.

Abdomen with fine and sparse punctation; punctation coarser and denser on VII; tergite each abdominal tergite with deep transverse depression at base.

Front tibia with 8 spines, apical two inserting on long teeth.

\section{Osorius alternans BERNHAUER, 1920: 137 (Figs 3a-f)}

\section{Type material examined:}

Peru: Lima, leg. Linke, 1 male without further data (syntype, FMNH); Bolivia: Yuracaris 1 female (syntype, FMNH).

\section{Additional material examined:}

Bolivia: Yuracaris, $1500 \mathrm{~m}$ elevation, 1 specimen (FMNH); Peru: San Ramon (75¹7' W, $\left.11^{\circ} 02^{\prime} \mathrm{W}\right)$, 1 specimen, 9.9.1906, leg. Iconikoff (FMNH); Iquitos, lowland forest, Rio Napo and Rio Sucusari, 1 specimen, Dec. 1998, leg. Bracley (BMNH); Loreto, Boqueron del Padre Abad, 7 specimens, 8.8.1946, leg. F. Woytkowski (AMNH); San Martin, 2 specimens, 9.3.194, leg. F. Woytkowski (AMNH); La Merced, $15 \mathrm{~km} \mathrm{E}$, Pasco, 1 specimen, 24.11.1971, leg. R.T. Schuh (AMNH); Bagua (78 30' W, 5³8' S), Montenegro,

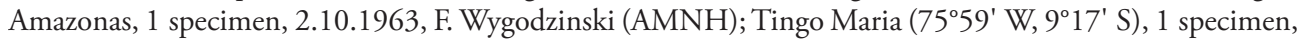
21.10.1947, leg. J. Pallister (AMNH); Madre de Dios, Manu National Park, Cocha Otorongo, under bark $\left(71^{\circ} 11^{\prime} 58 \mathrm{~W}, 12^{\circ} 02^{\prime} 1\right.$ S), 310 m elevation, 5 specimens, 21.10 .2000 leg. R.W. Brooks (KU, UIC); Villa Rica (74.50 W, 10.08 S); 15 km E, Pasco, 100 m elevation, 2 specimens, 24.11.1971, leg. R.T. Schuh (AMNH); Tambopata: Puerto Maldonado (69.12 W, 12.37 S), $15 \mathrm{~km} \mathrm{~N}$, ex molassas, $200 \mathrm{~m}$ elevation, 2 specimens, 11.07.1989, leg. J.S. Ashe (KU); Madre de Dios: Pentiacolla Lodge, Monk Saki Trail, under bark, 1 specimen, 25.10.2000, leg. R.W. Brooks (KU); Ecuador: Sucumbios, Sacha Lodge (76 $5^{\prime}$ W, $0^{\circ} 5^{\prime}$ S), 4 specimens, 22.03.1999, leg. R.W. Brooks (KU, UIC); Sacha Lodge, 5 specimens, 28.10.2004, leg. Rougemont (RC, UIC); La Bonita (77³2' W, 024'1 N), 17.5 km S, Santa Barbara Rd., 1 specimen, 11.10.1998, leg. D. Brzoska (KU); Napo, Jatun Sacha, $16 \mathrm{~km}$ E Puerto Napo, rain forest, under bark $\left(77^{\circ} 37^{\prime} 42 \mathrm{~W}\right.$, $1^{\circ} 03^{\prime} 57$ S), 1 specimen, 22.7.2009, leg. U. Irmler (UIC).

\section{Diagnosis:}

Bernhauer (1920) already mentioned the high similarity between $O$. alternans and $O$. stipes. Even the differences noted by Bernhauer could not be considered to be constant in a larger number of specimens. The short labrum mentioned by Bernhauer (1920) is no valid character, because the labrum in Osorius can be moved fore and back by the beetle and is thus variably covered by the 
clypeus. I found no significant constant characters to identify the two species except in the shape of the aedeagus. After studying the type species I was convinced that $O$. alternans is synonym to O. stipes. However, after the study of a number of specimens from the eastern Andean region, no variation was found in the aedeagus of the specimens of this region. It is clearly different from the Central Amazonian specimens. Thus, O. alternans seems to be a distinct species. The aedeagus in $O$. alternans has a short, very small, even apex, whereas the aedeagus in $O$. stipes has a longer acute apex.

\section{Description:}

Length: $11.5-13.5 \mathrm{~mm}$. Colour: black.

Head: $1.5-2.0 \mathrm{~mm}$ long, $2.5-3.1 \mathrm{~mm}$ wide; eyes not prominent; slightly shorter than temples; with numerous supraocular and postocular striae; irregular punctation moderately deep and dense; on average distance between punctures two times wider than diameter of punctures; an impunctate space at base of antennae and an adjacent space with sparser punctation on each side of disc; close to neck a further transversal space with sparser punctation; on each side of clypeus with denser granular punctation; few granular punctures also between eyes and neck; on each side of disc with two supraocular setiferous punctures and three setiferous punctures in front of eyes; microsculpture densely netlike reticulate; surface only slightly shiny.

Antennae one third longer than head; $2^{\text {nd }}$ antennomere short and globular; $3^{\text {rd }}$ antennomere nearly two times longer than $2^{\text {nd }}$; subsequent antennomeres slightly increasing in width; $4^{\text {th }}$ to $6^{\text {th }}$ antennomeres more or less quadrate; subsequent antennomeres slightly wider than long.

Pronotum: 2.1 - $2.5 \mathrm{~mm}$ long, 2.6 - $3.3 \mathrm{~mm}$ wide; widest at anterior tooth-like prominent angles; narrowed to posterior angles; in front of posterior angles slightly emarginate; a second smooth emargination in anterior half; lateral margin narrow in anterior half, widened in posterior half; punctation deep, but sparser than on head; distance between punctures 2.5 to 3 times wider than diameter of punctures; with small impunctate midline; midline with short furrow in posterior half; netlike microsculpture deeper and more distinct than on head; surface less shiny than on head.

Elytra: 2.6 - $3.3 \mathrm{~mm}$ long, 2.7 - $3.4 \mathrm{~mm}$ wide; with coriaceous ground sculpture, but without microsculpture; sparse punctation nearly invisible in coarse ground sculpture; surface shinier than on pronotum and head; nearly polished between striae of ground sculpture.

Aedeagus relatively slender with short apical part; apex obtuse and slightly curved back.

Osorius ashei sp. n. (Figs 20 a-d, 37 A)

\section{Type material:}

Holotype, male: Costa Rica: Puntarenas, Las Cruzes Biol. Stat. (0847.14' N, 82 $57.58^{\prime}$ W), $1330 \mathrm{~m}$ elevation, 28.-30.V.2004, leg. J.S. Ashe, Z. Falin, I. Hinojosa, collected by flight intercept trap, \#CR1AFH04 059 (KU).

\section{Diagnosis:}

The species resembles $O$. peruvianus in the overall shape, but the pronotum is without a trace of microsculpture. In this respect it is similar to O. laevigatulus. O. laevigatulus can be differentiated from $O$. ashei by the numerous supraocular striae which are absent in $O$. ashei. Furthermore, pronotal punctation in $O$. ashei is more distinct and seems denser than in O. laevigatulus. The shape of the aedeagus in $O$. ashei is unique by the plate-like apex and can not be confused with any other Osorius species. 


\section{Description:}

Length: $10.5 \mathrm{~mm}$. Colour: black.

Head: $1.5 \mathrm{~mm}$ long, $2.1 \mathrm{~mm}$ wide; eyes not prominent, slightly shorter than temples; front edge of clypeus with broad lateral prominences divided by a small gap and a seta inserting in gap; in emargination between lateral prominences; a broad semi-circular prominence; punctation deep and dense; distance between punctures on average as wide as to half as wide as diameter of punctures; on small spaces at base of antennae without or with sparse punctation; few short postocular striae and several granular punctures on a supraocular space; one granular puncture setiferous; microsculpture absent or very weakly developed on supraocular space.

Antennae with $2^{\text {nd }}$ antennomere short and globular, $3^{\text {rd }}$ antennomere at least twice as long as $2^{\text {nd }}$; subsequent antennomeres increasing in width; antennomeres 4 to 6 longer than wide; penultimate antennomeres more or less quadrate.

Pronotum: $1.9 \mathrm{~mm}$ long, $1.9 \mathrm{~mm}$ wide; widest at tooth-like prominent anterior angles; sides slightly narrowed in anterior half; more strongly narrowed in posterior half; a smooth emargination in front of posterior angles; lateral margin small in anterior half; distinctly widened in posterior half; punctation deep and dense; distance between punctures on average as wide as diameter of punctures; on small spaces in front of posterior angles or in midline with sparser or even absent punctation; distinct micro-punctation between coarse punctures, without microsculpture; surface polished; only near posterior angles with distinct netlike microsculpture; surface there matte.

Elytra: $2.4 \mathrm{~mm}$ long, $2.4 \mathrm{~mm}$ wide; with coriaceous ground sculpture and deep and dense punctation in ground sculpture visible.

Aedeagus relatively broad with short apical part; apex extremely broad ending in a more transparent platform compared to the basal part.

\section{Etymology:}

The species is dedicated to my dear colleague Prof. J. Ashe $\dagger$ who found this species during his intensive research in Costa Rica.

\section{Osorius ater PERTY, 1830: 30 (Figs 1a-d)}

\section{Type material examined:}

The two type specimens without any information on locality or collector are deposited in ZSM; one is labelled Osorius ater, the other is without label. According to information of the curator Dr. M. Baehr, both specimens are from Perty's collection. The one with label Osorius ater is fixed as lectotype.

\section{Additional material examined:}

Brazil: Rio de Janeiro ( $43^{\circ} 14^{\prime}$ W, $22^{\circ} 49^{\prime}$ S), with many other labels 2 specimens coll. Fermaire (IRSNB); Rio de Janeiro, coll. Camille van Voxem, 3 specimens (IRSNB); Rio de Janeiro with additional label Paraná, Minas Gerais, Caracai, 1.2.1885 leg. E. Gounelle; Bartacéna, coll C. van Voxem 1 specimen (IRSNB); Rio de Janeiro, Fry coll. 4 specimens; Rio de Janeiro, Corcovado, leg. Bryant, 17.12.1912, 2 specimens (BMNH); Rio de Janeiro, Corcovado, 1 specimen, 7.11.1963, B. Wygodzinski (AMNH); Magé, 70 km N Rio de Janeiro 2 specimens, 10.11.1999, leg. W. Grosser (JC); São Paulo, Piracicaba, Steel coll., 2 specimens (BMNH); Rio de Janeiro, 9 specimens, leg. Reinhardt (ZMUK); São Paulo, Piracicaba, Mata de Escola Superior Agricola Luiz der Queiroz, 01.05.1962, leg. J. Becker, 7 specimens (UIC); São Paulo, Serra Bocaina, 1650 m elevation, 1 specimen, 1.11.1969, leg. M. Alvarenga (AMNH); Espiritu Santo, 2 specimens, coll. Sharp, 4 specimens, coll. Cameron (BMNH); Santa Catharina, Fry coll. (BMNH); Brazil without further data 1 specimen (IRSNB); 
Petropolis 1 specimen (IRSNB), Theresopolis 1 specimen; Piquete, D. Morcina, 1500 m elevation, 1.12.1957, leg. H. Schubart (UIC); Serra de Bocaima, 1 specimen, 15.4.1961, leg. H. Nobregasd (UIC); Pinhal Grande $\left(50^{\circ} 13^{\prime} \mathrm{W}, 30^{\circ} 15^{\prime} \mathrm{S}\right), 1$ specimen, 15.12 .1947 and 15.1 .1948 , leg. A. Maller (AMNH); Corupa $\left(49^{\circ} 13^{\prime} \mathrm{W}\right.$, 26 26' S), Hansa Humboldt, 3 specimens, 15.10 .1948 and 15.11.1948, leg. A. Maller (AMNH); Rolandia $\left(51^{\circ} 22^{\prime}\right.$ W, $23^{\circ} 18^{\prime}$ S), 2 specimens, 15.10 .1947 , leg. A. Maller (AMNH); Santa Catharina, Cauna, 1 specimen, 15.11.1948, leg. A. Maller (AMNH); Nova Teutonia (52 $23^{\prime \prime}$ W, $27^{\circ} 11^{\prime}$ S), 1 specimen, 15.12.1946, leg. F. Plaumann (AMNH); 2 specimens, Jan. 1938 and Sept. 1939, leg. F. Plaumann (MS); Lages, South Brazil, 4 specimens, 15.11 .1948 (AMNH); Rio Grande do Sul, Represa, Guanabara, 1 specimen, 15.9.1969, leg. F.M. Oliveira (AMNH); Parana, 1 specimen, 15.10 .1900 , leg. B. Pohl (AMNH); Espirito Santo $\left(40^{\circ} 12^{\prime} \mathrm{W}\right.$, $20^{\circ} 05^{\prime}$ S), 2 specimens, 12.9.1914, leg. Hauschild (ZMUK); Lagoa Santa (435' W, 19³8' S), Minas Gerais, 12 specimens, leg. Reinhard (ZMUK); Minas Gerais, 2 specimens, leg. Reinhardt (ZMUK); Brazil, 2 specimens, leg. R.H. Stamm repectively leg. Westermann (ZMUK); Argentina: Ipiranga and Monte des Ozuges near Rio Missiones, 1 specimen (IRSNB); Paraguay: without further data,1 specimen, leg. Hauschild (ZMUK).

\section{Diagnosis:}

The clypeus with a pair of long and strong prominent teeth is unique in the Neotropical Osorius species. Clypeal teeth are found in some other species, but distinctly shorter and narrower.

\section{Description:}

Length: between 13.5 and $17.0 \mathrm{~mm}$. Colour: totally black.

Head: $3.0 \mathrm{~mm}$ long, $3.0 \mathrm{~mm}$ wide; distinctly and moderately sparse punctation; on average distance between punctures slightly wider than diameter; microsculpture distinct; netlike reticulate; surface scarcely shiny; anterior edge with a pair of long prominent teeth; in lateral aspect; anterior edge in front of eyes and lower dorsal edge forming a more or less rectangular angle; edge in front of eyes with four granular setiferous punctures; a supraocular area with seven granular punctures; on disc with four setae.

Antennae: antennomeres 4 to 10 more or less quadrate.

Pronotum: $2.5 \mathrm{~mm}$ long, $3.2 \mathrm{~mm}$ wide; widest at anterior angles; sides distinctly narrowed to the posterior angles; in front of posterior angles with short slight emargination; posterior angles forming a rectangular angle; surface sparsely punctate; distance between punctures on average more than twice as wide than diameter; microsculpture similar as on head; netlike reticulate; surface scarcely shiny; prosternum with ventral prominence at anterior edge.

Elytra: $2.0 \mathrm{~mm}$ long, $3.1 \mathrm{~mm}$ wide; with relatively large and dense punctures; distance between punctures not wider than diameter of punctures; surface slightly shiny; ground sculpture coriaceous; metanotum without setae.

Aedeagus with a very short apical part ending in an obtuse apex.

\section{Osorius boops SHARP, 1887: 679 (Figs 8 a-c)}

\section{Type material examined:}

Panama: Volcan de Chiriqui, 25 - 4000 ft, 1 male, leg. Champion (syntype, BMNH).

\section{Additional material examined:}

Costa Rica: San José, km 117 Pan-Am Hwy. 19 km N San Isidro (83.42.20 W, 9.28 N), 1880 m elevation, 2 specimens, 20-25 Jun.1997, leg. S \& J. Peck, CR 1 P97 023, from flight intercept trap (KU, UIC); Alajuela, Peńas Blancas, 800 m elevation, 1 specimen, 19. May 1989, from flight intercept trap, leg. J. Ashe, R. Brooks, R. Leschen (KU). 


\section{Diagnosis:}

The species can be easily distinguished from the other Osorius species by the prominent eyes and the narrow temples. In this respect it resembles $O$. affinis, although temples are not distinctly narrowed in $O$. affinis. Moreover, $O$. boops is distinctly larger than $O$. affinis, and $3^{\text {rd }}$ antennomere is twice as long as $2^{\text {nd }}$ antennomere.

\section{Description:}

Length: $8.0 \mathrm{~mm}$. Colour: black, elytra dark reddish, lighter reddish at shoulders, abdomen red; legs and antennae lighter red; posterior edge of pronotum reddish.

Head: $1.10 \mathrm{~mm}$ long, $1.50 \mathrm{~mm}$ wide; with eyes distinctly prominent and narrowed temples; clypeus with a broad lateral prominence and medially emarginate front edge; punctation fine and moderately sparse; distance between punctures approximately twice as wide as diameter of punctures; on average, surface with distinct isodiametric ground sculpture; scarcely shiny; few setiferous punctures on clypeus and some granular supraocular punctures at posterior edge of eyes; between eyes and neck two long setae.

Antennae as long as head and half of pronotum combined; $2^{\text {nd }}$ antennomere only half as long as elongate conical $3^{\text {rd }} ; 4^{\text {th }}$ antennomere again shorter; nearly as long as $2^{\text {nd }} ; 5^{\text {th }}$ antennomere longer and slightly wider; subsequent antennomeres wider than $5^{\text {th }}$, but decreasing in length.

Pronotum: $1.45 \mathrm{~mm}$ long, $1.65 \mathrm{~mm}$ wide; widest shortly behind anterior angles; narrowed to posterior angles with smooth emargination in front of posterior angles; lateral margin extremely small at anterior angles; distinctly widened to posterior angles; punctation similar as on head, but on average sparser; at least twice as wide as diameter of punctures; few setiferous punctures along lateral margin and one seta between midline and lateral margin near posterior third; surface with similar ground sculpture as on head and scarcely shiny.

Elytra: $1.90 \mathrm{~mm}$ long, $1.80 \mathrm{~mm}$ wide; with weak coriaceous ground sculpture; surface moderately shiny; punctation sparse and weak.

Aedeagus with apical part very long, slightly curved and ending in an acute apex.

\section{Osorius brasiliensis GuÉRIN, 1829 (Figs 4 a-f, 38 B)}

Osorius asymetricus FaUvel, 1901: 72 new synonymy

\section{Type material examined:}

Brazil: without further data, 1 female det. as $O$. tardus Dej (neotype, BMNH); Venezuela: 1 male without further data (syntype of O. asymetricus with remarks of Fauvel given by Sharp 'trés semblable a canaliculatus', (IRSNB).

Additional material examined:

Venezuela: Caripe $\left(10^{\circ} 10^{\prime} \mathrm{N}, 63^{\circ} 63^{\prime} \mathrm{W}\right), 7.4 .1998$, leg. M. v. Tschirnhaus, 21 specimens collected in rotten $\log$ (UIC); Caracas (66 $\left.53^{\prime} \mathrm{W}, 10^{\circ} 26^{\prime} \mathrm{N}\right)$, San Esteban $\left(70^{\circ} 06^{\prime} \mathrm{W}, 10^{\circ} 57^{\prime} \mathrm{N}\right), 1.11 .1888$, leg. Simon (O. asymetricus) (IRSNB); 1 specimen det. as O. intermedius by Cameron (BMNH); près de Puerto Cabello, 1 specimen, 1st trimestre 1877, leg. H. de Sagan (BMNH); as punctatellus Bernh. manuscript name, 1 specimen, Nov. 1888, leg. E. Simon (BMNH), 2 specimens, Nov. 1888, leg. E. Simon (BMNH, IRSNB); 1 specimen, Mus. Drews (ZMUK); Maracay $\left(67^{\circ} 35^{\prime} \mathrm{W}, 10^{\circ} 14^{\prime} \mathrm{N}\right) 19 \mathrm{~km} \mathrm{~N}$, road to Choroni, litter near stream, 1 specimen, 16.4.1994, leg. L. Herman; 1 specimen, 26.4.1946, leg. W. Beebe, Rancho Grande, 1 specimen, 21.6.1946, leg. W. Beebe (AMNH); Miranda (68 23' W; $\left.10^{\circ} 08^{\prime} \mathrm{N}\right), 19 \mathrm{~km} \mathrm{~N}$, road to Choroni, Agua Blanca, humid trop. forest, 1 specimen, 15.02.1987, leg. M.G. Paoletti (AMNH); Tovar (7145' W, $\left.8^{\circ} 20^{\prime} \mathrm{N}\right)$, 1 specimen, det. as $O$. asymetricus by Fauvel (IRSNB); Puerto Cabello $\left(68^{\circ} 00^{\prime} \mathrm{W}, 10^{\circ} 27^{\prime} \mathrm{N}\right), 1$ specimen, leg. 
E. Bugnion (IRSNB); Carabobo (61 $24^{\prime}$ W, 6 6 $18^{\prime}$ N), Mun. Bejuma, Via Palmichal, 1 specimen, 15.11.2005, leg. L. Brachat (AC); Trinidad: 1 specimen, 1904, leg. F. Birch (BMNH); Tobago, St. Mary's Pa. Gilpin Trace, 1 specimen, 14.6.1991, leg. D. Brzoska (KU); Guyana: without further data, 2 specimens, leg. Lansberg (ZMUK); French Guyana: 1 specimen without further data, coll. Sharp (BMNH); Roura (52 $19^{\prime}$ W, $\left.4^{\circ} 43^{\prime} \mathrm{N}\right)$,

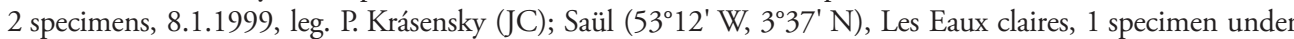
bark, 14.11.1995, leg. A. Berkov (AMNH); Matoury ( $\left.52^{\circ} 19^{\prime} \mathrm{W}, 4^{\circ} 50^{\prime} \mathrm{N}\right)$, trail, Sentier de la Miranda, primary tropical rainforest under wood and bark, 2 specimens, 18.12.2004, leg. J. Huff (AMNH); Suriname: Sarmaca, 1 specimen under bark, 6.8.1980, leg. M. Russell (BMNH); Columbia: Santa Marta $\left(74^{\circ} 08^{\prime} \mathrm{W}\right.$, $\left.11^{\circ} 13^{\prime} \mathrm{N}\right)$, Sierra Nevada, Buritaca-Remol ino trail, 1 specimen, 11.12.1974, leg. M. Cooper (BMNH); Columbia without further data, det. as tardus Déjean, Mus. Drews (ZMUK); Ecuador: 1 specimen, 1879, leg. Buckley (BMNH); Sucumbios, Shushufindi $\left(76^{\circ} 38^{\prime} \mathrm{W}, 0^{\circ} 11^{\prime} \mathrm{S}\right), 1$ specimen, 8.12.2004, leg. P. Banar (JC); 1 specimen without further data, 1879, leg. Buckley (BMNH); Brazil: Mato Grosso (51ํㄱ' W, 12²50' S), 1 specimen, 10.10.1968, gallery forest, leg. O. W. Richards (BMNH).

\section{Diagnosis:}

The species is very similar to $O$. intermedius and can be hardly distinguished from that species without analysis of the aedeagus. The indistinct depressions at the posterior angles of pronotum seem to be absent in $O$. intermedius, and the elytra seem to be more shiny in $O$. brasiliensis. The prosternal process in $O$. brasiliensis is more triangularly shaped than in O. intermedius and in apical aspect, the process is usually emarginate in the middle. However, the shape of the process is varying in both species and reflects no consistent character. The aedeagus in O. brasiliensis is slightly asymmetric with a straight short apex, while apex in $O$. intermedius is hook-like and thicker. As already mentioned for $O$. alternans, the asymmetric shape of labrum in $O$. asymmetricus described by FAUVEL (1901) is not valid because of the movable character of the labrum.

\section{Description:}

Length: $12.5-14.5 \mathrm{~mm}$. Colour: black.

Head: $1.8 \mathrm{~mm}$ long, $2.7 \mathrm{~mm}$ wide; with eyes half as long as temples; front edge of clypeus emarginate with two or three obtuse short lateral teeth on each side; central part of emargination indistinctly prominent; with reduced supraocular striae and distinct postocular striae; 3 to 4 supraocular granular setiferous punctures; punctation on disc distinct, but sparse; distance between punctures on average twice as wide as diameter of punctures; one granular setiferous puncture on each side of middle near neck; isodiametric microsculpture distinct; surface shiny.

Antennae with $2^{\text {nd }}$ antennomere oval; half as long as conical $3^{\text {rd }}$ antennomere; antennomeres 4 to 5 longer than wide and decreasing in length; subsequent antennomeres more or less quadrate, but penultimate antennomeres slightly shorter than $6^{\text {th }}$ antennomere.

Pronotum: $2.2 \mathrm{~mm}$ long, $2.8 \mathrm{~mm}$ wide; widest at tooth-like prominent anterior angles; in anterior half lateral margin small; distinctly widened to posterior angles; indistinct flat depression at posterior angles; punctation as dense and sparse as on head, but varying in size; with deeper and larger punctures near posterior edge and on lateral disc; between normal, large punctation with sparse micro-punctation; on each side of middle a slightly larger granular setiferous puncture; longitudinal depression in midline varying in depth; distinct microsculpture isodiametric; as deep as on head, but surface slightly mattet; anterior prosternal process triangular; with two or three granular setiferous punctures; front edge of process slightly concave.

Elytra: $3.0 \mathrm{~mm}$ long, $2.9 \mathrm{~mm}$ wide; with weak and sparse coriaceous ground sculpture; punctation deeper and larger than on pronotum, but distinctly sparser; without remains of microsculpture; surface nearly polished.

Aedeagus with short apical part; broad at base and abruptly narrowed shortly in front of acute apex. 


\section{Osorius canaliculatus SolsKY, 1870: 265 (Figs 7 a-c)}

\section{Material examined:}

Guatemala: Senahu (89 $49^{\prime}$ W, $\left.15^{\circ} 25^{\prime} \mathrm{N}\right), 1$ specimen, leg. Champion (BMNH); Nicaragua: San Carlos $\left(84^{\circ} 45 \mathrm{~N}, 11^{\circ} 07 \mathrm{~N}\right)$, Biologico Bartola, Selva alta perenifolia, ex troncos posridos, 2 specimens, 9.2.2000, leg. J. Marquez (UNAM); Costa Rica: Heredia: La Selva $\left(84^{\circ} 01^{\prime} \mathrm{W}\right.$, $\left.10^{\circ} 26^{\prime} \mathrm{N}\right), 3.2 \mathrm{~km} \mathrm{SE}$, P. Viejo, flight intercept trap, 1 specimen, 10.06.1996, leg. R. Hanley (KU), from misc. mushrooms, 1 specimen, 18.05.1993, leg. J.S. Ashe (KU); Puerto Viejo, Biol. Stat. (8359' W, $\left.10^{\circ} 26^{\prime} \mathrm{N}\right), 1$ specimen, 18.2.1985, leg. L. Herman (AMNH); Tapanti $\left(83^{\circ} 47^{\prime} \mathrm{W}, 9^{\circ} 42^{\prime} \mathrm{N}\right)$, Vicente, 1 specimen, 2.1941, leg. A. Bierig (AMNH); San José, Puerto Quepos ( $\left.84^{\circ} 10^{\prime} \mathrm{W}, 9^{\circ} 25^{\prime} \mathrm{N}\right)$, Rio Damitas, 1 specimen, 16.8.1962, leg. C.D. Michener (KU); Panama: La Fortuna $\left(82^{\circ} 12^{\prime} \mathrm{W}, 8^{\circ} 46^{\prime} \mathrm{N}\right)$, Estacion Biologica (82.12 W, $\left.8.46 \mathrm{~N}\right), 1250 \mathrm{~m}$ elevation, 3 specimens, 13.07.1995, leg. A.R. Gillogly (KU); Bocas del Toro (82 $\left.14{ }^{\prime} \mathrm{W}, 9^{\circ} 20^{\prime} \mathrm{N}\right)$, $7 \mathrm{~km}$ N Boquete, La Culebra trail, 3 specimens, 15.07.1995, leg. A.R. Gillogly (KU, UIC); Bugaba $\left(82^{\circ} 37^{\prime} \mathrm{W}, 8^{\circ} 28^{\prime} \mathrm{N}\right)$, leg. Champion (BMNH); Chiriqui, Tres de Noviembre Trail, upper Rio Chiriqui drainage, 1400 m elevation, 1 specimen, 2.1976, leg. C. Myers (AMNH).

\section{Diagnosis:}

The species is extremely variable in size, density of punctation, microsculpture on the fore body, and the shape of clypeal front edge. It resembles $O$. brasiliensis and $O$. intermedius in the absence of supraocular striae. Specimens of $O$. canaliculatus with distinctly developed microsculpture and punctation can hardly be distinguished from $O$. brasiliensis, whereas the presence of the depressions at posterior angles and the longitudinal depression in the midline of the pronotum are differentiating characters to $O$. intermedius. Those specimens can be distinguished from $O$. brasiliensis by the thick anterior prosternal process and the keel-like apex of the aedeagus. In O. canaliculatus the anterior prosternal process never shows a triangular shape in lateral aspect.

\section{Description:}

Length: $14.5-17.5 \mathrm{~mm}$. Colour: black.

Head: $1.8 \mathrm{~mm}$ long, $2.8-3.5 \mathrm{~mm}$ wide; eyes not prominent, half as long as temples; front edge of clypeus with broad; obtuse lateral prominence and emargination in between; lateral prominence divided into an outer broad obtuse tooth and an inner small acute tooth; in intermediate gap with setiferous puncture; anterior emargination with irregular wide medial prominence that might reach lateral prominence in size; punctation irregularly dense and deep; distance between punctures partly not wider than diameter of punctures, partly twice or more than three times wider than diameter of punctures; on clypeus several granular setiferous punctures; with few granular setiferous punctures on lateral disc; three to five supraocular granular setiferous punctures; without supraocular striae, but with few postocular striae; microsculpture moderately deep and dense varying in distinctness; surface thus varying between slightly shiny and nearly polished.

Antennae with $2^{\text {nd }}$ antennomere longer than wide, but only half as long as conical $3^{\text {rd }}$ antennomere; antennomeres 4 to 7 longer than wide, but successively decreasing in length; subsequent antennomeres quadrate.

Pronotum: 2.1 - $3.0 \mathrm{~mm}$ long, 2.7 - $3.7 \mathrm{~mm}$ wide; widest at anterior tooth-like prominent angles, with moderately distinct emargination in front of posterior angles; shape in anterior half varying from smoothly rounded to more or less straightly narrowed; lateral margin small at anterior angles; distinctly widened to posterior angles; at posterior angles with indistinct 
depression; with irregular punctation as on head; partly with larger punctures, partly with small punctures; micro-punctation also present; punctation varying in density; partly distance between punctures as wide as diameter of punctures, partly more than three times wider than diameter of punctures; microsculpture also varying between specimens from nearly absent to distinctly present; if present, microsculpture isodiametric; surface thus varying between nearly polished to slightly shiny; a distinct longitudinal depression always present; anterior prosternal process thick with at least 4 to 5 granular setiferous punctures in lateral aspect, anterior edge convex.

Elytra: 2.7 - $3.3 \mathrm{~mm}$ long, 2.7 - $3.3 \mathrm{~mm}$ wide; with coriaceous ground sculpture; sparse and large punctation scarcely visible in deep ground sculpture.

Aedeagus more or less circular, with carinate apex.

\section{Osorius columbinus BERNHAUER, 1920: 138 (Figs 6 a-c, 38 A)}

\section{Type material examined:}

Columbia: Carmen (744ㄴ W, $\left.4^{\circ} 09^{\prime} \mathrm{N}\right), 1400$ m, rain forest, 1 male, 30.5.1908 leg. Fassl (holotype, FMNH).

Additional material examined:

Columbia: 5 specimens without further data $(\mathrm{BMNH}) ; 2$ specimens without further data, Mus. Drews (ZMUK); Ecuador: Cotopaxi: Los Pampas, $20 \mathrm{~km} \mathrm{~S} \mathrm{La} \mathrm{Union} \mathrm{de} \mathrm{Toachi}\left(78^{\circ} 57^{\prime} \mathrm{W}, 0^{\circ} 18^{\prime} \mathrm{S}\right)$, rotten log, 1 specimen, 12.1.1992, leg. C.E. Carlton (KU); Pichincha: Tandapi (78 $\left.47^{\prime} \mathrm{W}, 0^{\circ} 25^{\prime} \mathrm{S}\right), 1460 \mathrm{~m}$ elevation, 3 specimens, 28.07.1967, leg. J.D. Lynch (KU, UIC); Maquipucuna $\left(78^{\circ} 37^{\prime} \mathrm{W}, 0^{\circ} 04^{\prime} \mathrm{N}\right), 50 \mathrm{~km} \mathrm{NW}$ Quito, 130 m elevation, 2 specimens, 21.12.1991, leg. C.E. Carlton (KU); Peru: Madre de Dios, Manu National Park $\left(71^{\circ} 11^{\prime} \mathrm{W}, 12^{\circ} 02^{\prime} \mathrm{S}\right)$, Cocha Oto rongo, 310 m elevation, 1 specimen under bark, 21.10.2000, leg. R.W. Brooks (KU).

\section{Diagnosis:}

The species is very similar to O. intermedius, but the coriaceous ground sculpture of elytra is distinctly deeper. Additionally, the lateral teeth of clypeus are more prominent than in $O$. intermedius. The aedeagus is characterised by an obtuse apex, whereas in $O$. intermedius apex of aedeagus is long and acute.

\section{Description:}

Length: $13.0 \mathrm{~mm}$. Colour: black.

Head: $2.0 \mathrm{~mm}$ long, $2.6 \mathrm{~mm}$ wide; deeply and densely punctate; distance between punctures on average as wide as or shorter than diameter of punctures; on clypeus several granular punctures; with isodiametric microsculpture; surface slightly shiny; front edge of clypeus with pair of distinct obtusely prominent teeth; central front emargination with wide slightly projecting prominence; labrum only slightly wider than long, distinctly projecting clypeal front emargination; eyes half as long as temples; dorsad to eyes and behind eyes with few short striae and few granular punctures. Antennae with $3^{\text {rd }}$ antennomere 1.5 times as long as $2^{\text {nd }}$; antennomeres 4 to 6 slightly longer than wide; subsequent antennomeres quadrate.

Pronotum: $2.2 \mathrm{~mm}$ long, $2.8 \mathrm{~mm}$ wide; widest at anterior acute tooth-like angles; distinctly narrowed to posterior angles; in front of posterior angles scarcely emarginate; lateral margin small at anterior angles; distinctly widened to posterior angles; punctation distinct and moderately 
dense; sparser than on head; on average distance between punctures wider than diameter of punctures; microsculpture as on head; surface slightly shiny; a longitudinal depression in posterior half of smooth midline; few granular punctures in front of posterior edge; posterior edge margined.

Elytra: $2.8 \mathrm{~mm}$ long, $2.8 \mathrm{~mm}$ wide; with coarse and dense, nearly invisible punctation between deep coriaceous ground sculpture; surface shiny.

Aedeagus broad, nearly circular with short apical part; apex also broad and obtuse, but not carinate.

Osorius confusus Notman, 1925: 10 (Figs 32 a-c, $38 \mathrm{H}$ )

\section{Type material examined:}

Mexico: Omelaca $\left(96^{\circ} 45^{\prime}\right.$ W, 1843' N), 1 male 16.4.1908. leg. F. Knab (holotype, AMNH).

Additional material examined:

Mexico: Puebla, Santa Lucia, $8 \mathrm{~km} \mathrm{SW}$ Cuetzalan $\left(97^{\circ} 31^{\prime} \mathrm{W}, 20^{\circ} 01^{\prime} \mathrm{N}\right)$ (AMNH), San Luis Potosi $\left(91^{\circ} 37^{\prime} \mathrm{W}, 16^{\circ} 36^{\prime} \mathrm{N}\right), 4$ specimens, $10 \mathrm{mi}$. E Xititla, 9.1.1952, leg. Creighton and 1 specimen, 24.11.1972, leg. J. Reddell (AMNH, UIC); Castle Ingles, Xilitla, 1 specimen, 7.7.1990, leg. Danoff-Burg (AMNH); Tlilipan, 2 specimens, 8.8.1967, leg. J. Reddell (ANHM, UIC).

\section{Diagnosis:}

The species is most similar to O. sablbergi in size, punctation and microsculpture of head and pronotum. The two species can only be distinctly differentiated by the shape of the aedeagus. Furthermore, in O. sablbergi microsculpture of the pronotum is generally isodiametric, while in $O$. confusus, sometimes a longitudinally reticulate microsculpture exists. Localities of both $O$. sablbergi and $O$. confusus are restricted to South Brazil and Mexico, respectively.

\section{Description:}

Length: $10.0 \mathrm{~mm}$. Colour: black.

Head: $1.40 \mathrm{~mm}$ long, $2.10 \mathrm{~mm}$ wide; eyes small, $1 / 3$ as long as temples; front margin with obtuse lateral teeth and a smoothly curved central prominence; densely and distinctly punctate; distance between punctures on average as wide as diameter of punctures; with several granular supraocular punctures and striae; surface with distinct netlike microsculpture; slightly shiny.

Antennae with $2^{\text {nd }}$ antennomere oval distinctly shorter than conical $3^{\text {rd }}$ one; antennomeres 4 to 6 longer than wide; subsequent ones more or less quadrate.

Pronotum: $1.85 \mathrm{~mm}$ long, $2.30 \mathrm{~mm}$ wide; widest at anterior edge; anterior angles tooth-like prominent; smoothly narrowed to posterior edge; in front of posterior angels slightly emarginate; lateral margin small at anterior angles and widened distad to posterior angels; midline deeply depressed beginning in anterior third and ending in front of posterior edge; surface with netlike or partly longitudinally reticulate microsculpture; slightly shiny.

Elytra: $2.10 \mathrm{~mm}$ long, $2.30 \mathrm{~mm}$ wide; with coriaceous ground sculpture and weak and sparse punctation.

Abdomen without dorsal punctation.

Front legs with 9 spines at outer edge; apical 4 ones on larger teeth; a row of approximately 10 hairs parallel to outer edge and a second row with few setae at inner side.

Aedeagus broad and nearly circular with short apical part; apical part extremely asymmetric pointing to left side; suddenly narrowed in front of acute apex. 
Osorius continentalus sp. n. (Figs 30 a-c, 37 C)

\section{Type material:}

Holotype, male: Panama: Bocas do Toro, 3 km W of Fortuna Hwy. continental divide, $1050 \mathrm{~m}$ elevation, 12.7.1995, leg. A. Gillogly (KU).

\section{Diagnosis:}

The species resembles $O$. morio, $O$. laevicollis, and $O$. dubius in size or shape of pronotum. It is slightly longer than $O$. laevicollis. Compared to $O$. morio, punctation of elytra is much more indistinct. In O. morio, elytral punctation is distinctly visible and larger. Compared to O. laevicollis, microsculpture of pronotum is isodiametric, while it is netlike in O. laevicollis. Antennae are more slender than in $O$. laevicollis. Compared to $O$. dubius, surface of pronotum is shinier and punctation is denser and deeper.

\section{Description:}

Length: $9.0 \mathrm{~mm}$. Colour: black.

Head: $1.3 \mathrm{~mm}$ long, $1.7 \mathrm{~mm}$ wide; eyes not prominent, front edge of clypeus with lateral denticulate prominences and a deep emargination in between; an indistinct obtuse prominence in central emargination; punctation deep and moderately dense; distance between punctures on average as wide as or slightly wider than diameter of punctures; a space at base of antennae without punctures; with few postocular striae; with weak isodiametric microsculpture, surface shiny.

Antennae with $2^{\text {nd }}$ antennomere more or less globular; $3^{\text {rd }}$ antennomere conical and only slightly longer than $2^{\text {nd }}$; subsequent antennomeres increasing in width; antennomeres 4 to 6 longer than wide; $7^{\text {th }}$ antennomere quadrate; subsequent antennomeres slightly wider than long.

Pronotum: $1.7 \mathrm{~mm}$ long, $1.9 \mathrm{~mm}$ wide; with acute tooth-like anterior angles; sides behind anterior angles slightly narrowed; nearly parallel; distad from middle to posterior angles distinctly narrowed and slightly emarginate; lateral margin narrow behind anterior angles; distad widened to posterior angles; punctation similar to head, but slightly sparser; weak microsculpture isodiametric; surface shiny.

Elytra: $2.0 \mathrm{~mm}$ long, $1.9 \mathrm{~mm}$ wide; with coriaceous ground sculpture; punctation scarcely visible in deep ground sculpture.

Aedeagus with long triangular apex; ending in an acute top.

\section{Etymology:}

The species name derived from 'continent' and refers to the location at continental divide Hwy, where it was found.

\section{Osorius costaricensis BERNHAUER, 1942: 7 (Figs 12 a-c)}

\section{Type material examined:}

Costa Rica: Reventazon $\left(83^{\circ} 28^{\prime} \mathrm{W}, 10^{\circ} 10^{\prime} \mathrm{N}\right), 2$ males without further data (syntypes, FMNH).

\section{Additional material examined:}

Guatemala: La Union $\left(89^{\circ} 17^{\prime} \mathrm{W}, 14^{\circ} 58^{\prime} \mathrm{N}\right), 3.5 \mathrm{~km} \mathrm{SE}$, under bark, 6 specimens, 25.6.1993, leg. J.S. Ashe (KU, UIC); Honduras: Franzisco Morazan, 7.6 km N Guaimaca (86 $\left.49^{\circ} \mathrm{W}, 14^{\circ} 36^{\prime} \mathrm{N}\right)$, under bark, $820 \mathrm{~m}$ elevation, 3 specimens, 26.6.1994, J.S. Ashe (KU); Nicaragua: Matagalpa $\left(85^{\circ} 54^{\prime} \mathrm{W}, 12^{\circ} 54^{\prime} \mathrm{N}\right), 10 \mathrm{~km}$ 
NW, Selva Negra, leaf litter at stream, 1 specimen, 22.5.2002, leg. L. Herman (AMNH); Isla de Ometepec $\left(85^{\circ} 34.55 \mathrm{~W}, 11^{\circ} 24.71 \mathrm{~N}\right)$, Volcan Maderas, ex troncos podridos, $746 \mathrm{~m}$ elevation, 3 specimens, 30.1.2000, leg. J. Marquez (UNAM); Granada $\left(85^{\circ} 57\right.$ W, $11^{\circ} 55$ N), Res. Nat. Volcan Mombacho, under bark, $375 \mathrm{~m}$ elevation, 1 specimen, 2.2.2000, leg. J. Marquez (UNAM); Costa Rica: Heredia: La Selva $\left(84^{\circ} 01^{\prime}\right.$ W, $\left.10^{\circ} 26^{\prime} \mathrm{N}\right), 3.2 \mathrm{~km}$ SE Puerto Viejo, flight intercept trap, 3 specimens, 21.3.1992, 1 specimen, 17.2.1992, 1 specimen, 14.2.1992, leg. W. Bell (KU); Alajuela: Rio Penas Blancas, under bark, 6 specimens, 18.5.1989, leg. J.S Ashe (KU, UIC); Monteverde, Malaise trap, 1 specimen, 9.5.1989, leg. J.S. Ashe (KU); Santa Elena Puntarenas $\left(82^{\circ} 47.85 \mathrm{~W}, 8^{\circ} 55.26 \mathrm{~N}\right)$, Area de proteccion, Sierra de Talamanca, Selva alta subperenifolia, troncos con hongos fumigados, $1535 \mathrm{~m}$ elevation, 1 specimen, 26.2.2000, leg. J. Marquez (UNAM); Panama: Bocas del Toro, 7 km N Boquete, La Culebra trail, 5 specimens, 15.7.1995, leg. A.R. Gillogly (KU, UIC).

\section{Diagnosis:}

O. costaricensis is one of the smallest species of Neotropical Osorius. In this respect it can be confused with $O$. dentatus, $O$. paganus and $O$. sublaevis. In contrast to $O$. dentatus, the surface of pronotum in $O$. costaricensis is matte at the distinct microsculpture, whereas surface is shiny in $O$. dentatus. In contrast to $O$. sublaevis, punctation in $O$. coastaricensis is sparser and finer. In particular, it resembles $O$. paganus in size, microsculpture and punctation. $O$. costaricensis is more slender in the overall feature than $O$. paganus, and postocular striae are present that are absent in $O$. paganus. Moreover, the aedeagus in $O$. paganus is extremely long and acute, whereas it is shorter and with obtuse apex in $O$. costaricensis.

\section{Description:}

Length: 6.5 - $7.8 \mathrm{~mm}$. Colour: black, legs and antennae brown.

Head: $0.9-1.2 \mathrm{~mm}$ long, $1.2-1.5 \mathrm{~mm}$ wide; eyes not prominent, front edge of clypeus with broad, obtuse lateral prominence divided by a gap with a setiferous puncture; punctation moderately deep and dense, distance between punctures on average as wide as or 1.5 times wider than diameter of punctures; with sparse micro-punctation, microsculpture weak and isodiametric; surface shiny; on posterior portion of clypeus with two granular setiferous punctures on each side; three supraocular setiferous punctures and a pair of postocular setiferous punctures; with few short, postocular striae. Antennae with more or less circular $2^{\text {nd }}$ antennomere; $3^{\text {rd }}$ conical antennomere only slightly longer than $2^{\text {nd }}$; subsequent antennomeres increasing in width; $4^{\text {th }}$ antennomere quadrate; $10^{\text {th }}$ antennomere wider than long.

Pronotum: 1.2 - $1.4 \mathrm{~mm}$ long, 1.3 - $1.7 \mathrm{~mm}$ wide; widest at anterior angles; lateral margin small at anterior angles; distinctly widened in posterior half; punctation sparser and finer than on head; distance between punctures at least twice as long as diameter of punctures; a small midline without punctures; a transverse row of five setiferous punctures along front edge and two pairs of setiferous punctures in posterior half; one pair laterad in posterior third and one pair near midline in front of posterior edge; with distinct isodiametric microsculpture; surface matte.

Elytra: 1.4 - $1.8 \mathrm{~mm}$ long, 1.3 - $1.6 \mathrm{~mm}$ wide; with deep coriaceous ground sculpture; punctation nearly invisible, surface shiny.

Aedeagus broad, nearly circular; with long apex in relation to short basal part; apex curved.

Osorius dentatus BernHAUER, 1908: 294 (Figs 11 a-d, 38 C)

\section{Type material examined:}

Bolivia: Mapiri (68.09 W, 15.15 S) 1 male without further data (holotype, FMNH). 


\section{Diagnosis:}

Concerning size, O. dentatus is nearly as small as O. costaricensis, O. paganus and O. sublaevis, but microsculpture of pronotum is weaker and surface shinier in $O$. dentatus. Moreover, a micropunctation exists on the pronotum that is not found in the other species of similar size. A shiny pronotal surface is also found in O. wasmanni, but $O$. wasmanni is much larger $(9.5 \mathrm{~mm})$ and with a distinct longitudinal depression in the midline of the pronotum.

\section{Description:}

Length: $7.2 \mathrm{~mm}$. Colour: black; elytra slightly lighter; dark brown.

Head: $1.1 \mathrm{~mm}$ long, $1.3 \mathrm{~mm}$ wide; deeply and densely punctate; distance between punctures on average shorter than diameter of punctures; isodiametric microsculpture deep; surface slightly shiny; front angles of clypeus shortly prominent; at inner side diagonally retreated and with few short setae; labrum short, scarcely projecting clypeal emargination; eyes, as large as temples, semi-circularly projecting head; with several short supraocular and postocular striae and granular punctures; with two supraocular setae.

Antennae with $2^{\text {nd }}$ antennomere oval; $3^{\text {rd }}$ one conical and as long as $2^{\text {nd }}$; antennomeres 4 and 5 slightly longer than wide; subsequent ones quadrate.

Pronotum: $1.4 \mathrm{~mm}$ long, $1.6 \mathrm{~mm}$ wide; widest at tooth-like front angles; sides continuously narrowed to posterior angles; lateral margin narrow at front angles and only slightly wider at posterior angles; posterior angles more or less obtusely rounded; front and posterior edge margined; punctation deep and dense; distance between punctures on average as wide as or shorter than diameter of punctures; with large smooth midline; more or less isodiametric microsculpture weak; surface nearly polished.

Elytra: $1.6 \mathrm{~mm}$ long, $1.5 \mathrm{~mm}$ wide; with coarse punctation; scarcely visible between deep coriaceous ground sculpture; an indistinct longitudinal depression behind shoulders on disc.

Aedeagus nearly quadrate with long, curved apical part ending in acute apex.

\section{Osorius dubius SHARP, 1887: 679 (Figs 27 a-c, 38 G)}

Osorius laevigatus SHARP, 1887, 679 new synonymy

Type material examined:

Panama: Volcan de Chiriqui, 25 - $4000 \mathrm{ft}$ elevation, 1 male, 1 female, leg. Champion (syntypes, BMNH); Guatemala: Vera Paz, Sinanja, 1 male, leg. Champion (syntype of O. laevigatus, $\mathrm{BMNH})$.

\section{Additional material examined:}

Belize: Olancho $\left(86^{\circ} 42^{\prime}, 15^{\circ} 06^{\prime} \mathrm{N}\right)$, under bark, La Muralla, $1450 \mathrm{~m}$ elevation, 1 specimen, 25.6.1994, leg. J.S. Ashe (KU); Honduras: Yoro $\left(8^{\circ} 37^{\prime}, 15^{\circ} 09^{\prime} \mathrm{N}\right)$, P.N. Pico Pijol, upper montane forest litter, $1300 \mathrm{~m}$ elevation, 2 specimens, 11.5.2002, leg. R. Anderson (KU); Cortez (87 $\left.58^{\prime} \mathrm{W}, 1^{\circ} 55^{\prime} \mathrm{N}\right)$, Yojo Lake, Deer Island, flight intercept trap, $670 \mathrm{~m}$ elevation, 1 specimen, 26.6.1994, leg. J.S.Ashe (KU); Santa Barbara, $11.5 \mathrm{~km} \mathrm{~S} ; 5.6 \mathrm{~km} \mathrm{~W}$. Peña Blanca $\left(88^{\circ} 02^{\prime} \mathrm{W}, 14^{\circ} 57^{\prime} \mathrm{N}\right)$, beating stick pile, $1800 \mathrm{~m}$ elevation, 1 specimen, 20.06.1994, leg. R.W. Brooks (KU); Costa Rica: Monteverde, Estacion Biologica, cloud forest litter, 4 specimens, 10.6.2001, leg. R. Anderson, 1 specimen, 12.5.1989, leg. J.S. Ashe (KU, UIC); 1 specimen, SEM Costa Rica Exp., $1550 \mathrm{~m}$ elevation, 7 specimens, 12.5., 14.5., 15.5., 21.5., 22.5.1989, 2 specimens under bark, 12.5.1989, 1 specimen in small brown-spored gilled mushrooms at $1430 \mathrm{~m}$ elevation, 28.5.1989, leg. J.S. Ashe (KU, UIC); cloud forest litter $\left(84^{\circ} 47^{\prime} \mathrm{W}, 10^{\circ} 18^{\prime} \mathrm{N}\right), 1800 \mathrm{~m}$ elevation, 1 specimen, 13.6.2001, leg. 
R. Anderson (KU); Monteverde, lower montane forest litter, buried surface of decayed log, $1500 \mathrm{~m}$ elevation, 10 specimens, 11.2.1989, leg. D.A. Grimaldi (AMNH, UIC); Monteverde, Cerro Amigos, leaf litter at base of tree, $1785 \mathrm{~m}$ elevation, 2 specimens, 22.5.1989, leg. J.S. Ashe (KU); Campbell's woods, $1550 \mathrm{~m}$ elevation, 2 specimens, 9.5.1989, 11.5.1989, leg. J.S. Ashe (KU); San José, km 45 Pan Am Hwy, 6 km NE El Empalme, forest litter, by Berlese, 1975 m elevation, 1 specimen, 8.6.1997, leg. R. Anderson (KU); Pan American Hwy km 113, 23 km N San Isidro (8342' W, 9²9' N), 2000 m elevation, 1 specimen by Berlese, 20.6.1997, leg. J.S. Ashe, (KU); 2.4 km ENE Sn Gerardo de Rivas (833' W, $9^{\circ} 28^{\prime} \mathrm{N}$ ), Cloudebridge Res. Ridge trail, under bark, 2100 m elevation, 2 specimens, 9.6.2004, 10.6.2004, leg. J.S. Ashe (KU); Guanacaste, Conservation area, Patilla field St., cloud forest litter, 2 specimens, 14.2.1996, leg. R. Anderson (KU); Santa Elena Cloud Forest Res. cloud forest litter $\left(84^{\circ} 47^{\prime} \mathrm{N}, 10^{\circ} 20^{\prime} \mathrm{N}\right), 1650 \mathrm{~m}$ elevation, 3 specimens, 11.6.2001, leg. R. Anderson (KU); Puntarenas, Las Alturas, Altamira Biol Stn. ( $\left.82^{\circ} 50^{\prime} \mathrm{W}, 8^{\circ} 56^{\prime} \mathrm{N}\right)$, flight intercept trap, 1660 m elevation, 2 specimens, 3.6.2004, under bark, 1660 m elevation, 1 specimen, 1.6.2004, inside hepialid webs on trees, 1600 m elevation, 1 specimen, 6.6.2004, leg. J.S. Ashe (KU); at: San Vito Biol. Stat., Las Alturas, $1500 \mathrm{~m}$ elevation, 1 specimen, 15.1.1992, leg. P. Hanson (KU); Cerro Amigos, sifted leaf litter, $1780 \mathrm{~m}$ elevation, 1 specimen, 9.5.1989, leg. J.S. Ashe (KU); San Ramón (84²8' W, $\left.10^{\circ} 04^{\prime} \mathrm{W}\right), 27 \mathrm{~km} \mathrm{~N} \& 8 \mathrm{~km} \mathrm{~W}$, flight intercept trap, 15.6.1997, leg. J.S. Ashe (KU); Alajuela, Rio Penas Blancas ( $\left.84^{\circ} 28^{\prime} \mathrm{W}, 10^{\circ} 04^{\prime} \mathrm{N}\right)$, flight intercept trap, 875 m elevation, 1 specimen, 19.5.1989, leg. J.S. Ashe (KU); Cartago, Palo Alto Valley, $1500 \mathrm{~m}$ elevation, 8 km S Orosi (8351' W, 943' N), 1 specimen, 25.5.1992, leg. M.E. Jameson (KU); Orosi, 8 km S, Embalse, El Llano, flight intercept trap, 1500 m elevation, 1 specimen, 8.6.1992, leg. M.E. Jameson (KU); Tuis 2 km NE, Rancho Naturalista ( $83^{\circ} 33^{\prime}$ W, 949' N), 2500 m elevation, 1 specimen, 16.5.1995, leg. B. Ratcliffe (KU); at: 9 km N Varablanca, El Angel Falls, 1 specimen, 9.7.1964, leg. G.C. Eickwort (KU); Par. Nat. Tapanti, forest litter, Berlese, 1750 m elevation, 1 specimen, 4.6.1997, leg. R. Anderson (KU); Santa Cruz de Turrialba, Rt 230, litter nr. stream, 1 specimen, 13.3.1991, leg. L. Herman (AMNH); 15.5 km N Jct. Rts. 126(9) and 120, $12 \mathrm{~km}$ E RD to Virgen de Soccorro, Rio Sarpiqui, leaf litter from shore of Rio and banks, $750 \mathrm{~m}$ elevation, 1 specimen, 28.3.1991, leg. L. Herman (AMNH); San Vito (8258' W, 903' N), 35 km NE, nr. Las Alturas, Rio Bella Vista, wet leaf litter, 1300 m elevation, 2 specimens, 23.3.1991, leg. L. Herman (AMNH); Panama:

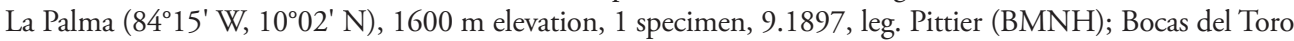
(82¹4' W, 9²0' N), 2 km W, Fortunata; Hwy Continental divide, 1 specimen, 20.6.1995, 3 km W Fortunata Hwy, continental divide, 1050 m elevation, 1 specimen, 12.7.1995, leg. A.R Gillogly (KU); Chiriqui, Palo Alto Valley $4 \mathrm{~km}$ E Boquete ( $82^{\circ} 23^{\prime}$ W, $8^{\circ} 46$ N), 1600 m elevation, 2 specimens, 11.08.1995, leg. A.R Gillogly (KU); 3.5 km NE Santa Clara, Hartmann's Finca, Ojo (79 $41^{\prime}$ W, $9^{\circ} 03$ N), 1450 m elevation, 2 specimens, 23.5.1995, leg. A.R Gillogly (KU); Hornito $\left(82^{\circ} 12^{\prime} \mathrm{W}, 8^{\circ} 39^{\prime} \mathrm{N}\right)$, Finca la Suiza, flight intercept trap, 1220 elevation, 2 specimens, 6.6.2000, 30.5.2000, leg. A. Howden (KU); $6 \mathrm{~km}$ NE Boquete, under bark, $1500 \mathrm{~m}$ elevation, 1 specimen, 14.6.1996, leg. J.S. Ashe (KU); La Fortuna (82 $\left.12^{\prime} \mathrm{W}, 8^{\circ} 46^{\prime} \mathrm{N}\right)$, Continental Divide Trail, under bark, 1080 m elevation, 2 specimens, 21.5.1995, leg. J.S. Ashe (KU); 20 km N. Gualaca, Finca la Suiza, fungousy log, $1350 \mathrm{~m}$ elevation, 1 specimen, 22.5.1995, leg. J.S. Ashe (KU).

\section{Diagnosis:}

The species resembles $O$. morio, $O$. piceus and $O$. continentalus in size and microsculpture of the pronotum. It can be distinguished from these species by the fine and sparse pronotal punctation and the deeper and narrower microsculpture with matter pronotal surface than in the three similar species.

\section{Description:}

Length: $9.0 \mathrm{~mm}$. Colour: black; tarsi and antennae dark red.

Head: $1.25 \mathrm{~mm}$ long, $1.75 \mathrm{~mm}$ wide; with eyes scarcely prominent; broad lateral prominence of clypeus undulate; punctation moderately fine and sparse; distance between punctures on average as wide as diameter of punctures; with granular supraocular punctures; on clypeus punctures with extremely short setae and a pair of longer setae; on disk without setiferous punctures; only one supraocular seta on each side behind posterior edge of eyes; laterad temples striate; surface with very weak isodiametric microsculpture; surface nearly polished. 
Antennae with $2^{\text {nd }}$ antennomere globular, not longer than wide; $3^{\text {rd }}$ antennomere conical, 1.5 times longer than $2^{\text {nd }}$ one; antennomeres 4 and 5 more or less quadrate, but distinctly smaller than quadrate subsequent antennomeres.

Pronotum: $1.50 \mathrm{~mm}$ long, $1.75 \mathrm{~mm}$ wide; widest at anterior angles; more or less strongly narrowed to posterior angles; scarcely emarginate in front of posterior angles; anterior angles with shortly tooth-like prominence; lateral margin small at anterior angles, widened to posterior angles; punctation fine and sparse; distance between punctures on average twice as wide as diameter of punctures; with small impunctate midline and short furrow in posterior half; surface with distinct isodiametric microsculpture; surface nearly shiny.

Elytra: $2.0 \mathrm{~mm}$ long, $1.75 \mathrm{~mm}$ wide; with deep coriaceous ground sculpture; surface dull; punctation scarcely visible.

Abdominal tergites with weak netlike microsculpture; punctation extremely fine and sparse except a transverse row of larger setiferous punctures along posterior edge of abdominal tergites.

Aedeagus broad, nearly circular with short apical part; apex obtuse and slightly curved.

\section{Remarks:}

SHARP (1887) already mentioned the strong similarity between $O$. dubius and O. laevigatus. The study of the syntypes of the two Osorius species asserted the difference found by SHARP (1887). However, within a large collection of specimens, a high variety consists concerning the shape of the front edge of clypeus. As no differences were found in the aedeagus of $O$. dubius and $O$. laevigatus, the two species have been synonymised.

Osorius granulatus BeRnHAUER, 1920: 137 (Fig. 10 a-b, 39 C)

\section{Type material examined:}

Brazil: Rio de Janeiro, Colonia alpina 1 female (holotype, FMNH).

Additional material examined:

Brazil: Amapa, Serra de Navio, 1 female, 5.12.1959, leg. R. Arlé (UIC).

\section{Diagnosis:}

The species can be differentiated from the similar large species by the granular punctation of the head and the distinctly thicker last antennomeres. Unfortunately, only females could be studied.

\section{Description:}

Length: $9.5 \mathrm{~mm}$. Colour: black.

Head: $1.5 \mathrm{~mm}$ long, $1.8 \mathrm{~mm}$ wide; punctation moderately dense; a large area on posterior portion of head without punctures; front head with dense granular punctures; two small areas dorsad of antennal base without punctures; isodiametric microsculpture dense and deep; surface scarcely shiny; clypeus with obtuse, distinctly prominent angles; between tooth-like angles with deep emargination; labrum more than twice as wide as long; scarcely projecting clypeal emargination; eyes $1 / 3 \mathrm{rd}$ as long as temples; with few short striae behind eyes and several granular punctures dorsad to eyes.

Antennae thick and stout; $2^{\text {nd }}$ antennomere oval; $3^{\text {rd }}$ one conical and as long as $2^{\text {nd }}$; antennomeres 4 to 6 quadrate; subsequent antennomeres wider than long and much thicker than preceding ones. 
Pronotum: $1.6 \mathrm{~mm}$ long, $1.8 \mathrm{~mm}$ wide; widest at tooth-like anterior angles; more or less continuously narrowed to posterior angles; lateral margin narrow at anterior angles; slightly wider at posterior angles; posterior edge margined; punctation deep and sparse; distance between punctures at least two times wider than diameter of punctures; with smooth non-punctuate midline; isodiametric microsculpture deep and dense; surface scarcely shiny.

Elytra: $2.0 \mathrm{~mm}$ long, $1.8 \mathrm{~mm}$ wide; with weak coriaceous ground sculpture and few granular punctures; surface shiny.

Osorius guianensis sp. n. (Figs 26 a-c, 37 D)

\section{Type material:}

Holotype, male: British Guyana: Kamakusa, Jan. 1923, without information about the collector, but with No. Acc. 24895 (AMNH).

Paratypes: one male with the same data as in holotype (AMNH); French Guyana: Saül, Eaux Claires, 3.5 mi N Saül (338-40' N, 5313-14' W), 155-260 m elevation, 2 males, Oct $/ 5$ $13 / 95$, leg. L. Herman, collected in fig fruit fall (AMNH, UIC).

\section{Diagnosis:}

The species is extremely similar to Osorius brasiliensis and O. stipes/alternans concerning overall feature, shape of aedeagus, and density of punctation on pronotum. However, it is smaller than the two species. Striae of head are also present in the supraocular space as in O. stipes/alternans, whereas they are only present in the postocular space in $O$. brasiliensis. Aedeagus is very similar to both species. In $O$. guianensis, apex of aedeagus is pointing backwards as in O. alternans, whereas it is straight in $O$. brasiliensis. In $O$. guianensis, aedeagus is broader than in $O$. stipes, $O$. alternans, and $O$. brasiliensis.

\section{Description:}

Length: $11.0 \mathrm{~mm}$. Colour: black, antennae and legs dark brown.

Head: $1.7 \mathrm{~mm}$ long, $2.3 \mathrm{~mm}$ wide; with short, not prominent eyes; temples twice as long as eyes; front edge of clypeus dilated at both outer angles and with central emargination; front edge undulate; with numerous supraocular striae continued behind eyes; punctation deep and dense, but irregular; a space at base of antennae, in centre of clypeus, and at posterior disc without punctures; on average, distance between punctures half as wide as diameter of punctures; with two supraocular, setiferous and granular punctures; a pair of setiferous punctures on disc near neck; a few setiferous punctures in front of anterior edge of eyes; surface without microsculpture, shiny. Antennae with $2^{\text {nd }}$ antennomere short, but longer than wide; $3^{\text {rd }}$ antennomere 1.5 times as long as $2^{\text {nd }}$; subsequent antennomeres increasing in width; $4^{\text {th }}$ and $5^{\text {th }}$ antennomeres quadrate; subsequent antennomeres slightly wider than long.

Pronotum: $1.9 \mathrm{~mm}$ long, $1.9 \mathrm{~mm}$ wide; widest at anterior angles; anterior angles tooth-like prominent; sides behind anterior angles slightly narrowed in anterior half; in posterior half distinctly narrowed; a weak lateral emargination in front of posterior angles; lateral margin narrow at anterior angles; distinctly widened in posterior half; punctation deep and dense, but on average less dense than on head; short midline impunctate and with a longitudinal stria in posterior half; distance between punctures irregularly; between half as wide as to as wide as diameter of punctures; near depression at posterior angles with sparser punctation; with weak netlike microsculpture, but surface nevertheless shiny. 
Elytra: $2.4 \mathrm{~mm}$ long, $2.4 \mathrm{~mm}$ wide; with deep coriaceous ground sculpture; surface less shiny than on pronotum.

Abdomen with extremely sparse and fine punctation; microsculpture on first visible tergite deep and distinct; surface matte; on subsequent tergites microsculpture weaker and surface shinier; on tergite VIII with numerous granular punctures.

Aedeagus short and broad, pear-shaped in ventral aspect; apex short, pointing shortly backwards.

\section{Etymology:}

The specific name derived from the region where the species was found.

\section{Osorius integer SHARP, 1876: 384 (Figs 24 a-c)}

\section{Type material examined:}

Brazil: Amazonas: Tefé, 1 male, without further data (holotype, BMNH).

Additional material examined:

Ecuador: Rio Napo, Onkone Gare Camp (76 $\left.26^{\prime} \mathrm{W}, 0^{\circ} 39^{\prime} \mathrm{S}\right)$, terra firme forest, flower fall leaf litter, at night, 220 m elevation, 1 female, 8.10.1995, leg. G.E. Ball (KU).

\section{Diagnosis:}

The species resembles $O$. laevigatus, $O$. wasmanni and $O$. peruvianus in size and punctation of the pronotum. It can be distinguished from $O$. laevigatus and $O$. wasmanni by a weak microsculpture on the pronotum that is absent in O. laevigatus and O. wasmanni. In contrast to O. peruvianus, postocular striae are absent.

\section{Description:}

Length: $9.3 \mathrm{~mm}$. Colour: black; legs and antennae dark brown.

Head: $1.40 \mathrm{~mm}$ long, $1.80 \mathrm{~mm}$ wide; short eyes slightly prominent, not longer than temples; lateral edge of clypeus only slightly emarginate; base of mandibles scarcely visible in dorsal aspect; front edge of clypeus straight with an obtuse short lateral prominence; surface deeply and densely punctate; distance between punctures as wide as to moderately shorter than diameter of punctures; with feeble and close microsculpture; surface more or less shiny; with several supraocular and postocular striae and several granular setiferous punctures.

Antennae with $2^{\text {nd }}$ antennomere short and globular; $3^{\text {rd }}$ one conical and slightly longer than $2^{\text {nd }}$ one; subsequent antennomeres more or less quadrate increasing in width.

Pronotum: $1.75 \mathrm{~mm}$ long, $2.00 \mathrm{~mm}$ wide; widest at anterior edge with tooth-like prominent front angles; continuously narrowed to posterior edge; slightly emarginate in front of posterior angles; lateral margin narrow at front angles; distad from middle distinctly widened to posterior angles; punctation deep and dense, but on average less dense than on head; distance between punctures slightly wider than diameter of punctures, but on some parts also closer than diameter of punctures, in particular, adjacent to small impunctate midline; with shortly depressed furrow in posterior half.

Elytra: $2.15 \mathrm{~mm}$ long, $2.15 \mathrm{~mm}$ wide; with elongate and deep punctures, in particular, at base with striate punctures; moderately dense punctation slightly sparser than on pronotum; surface without microsculpture; shiny. 
Abdomen with fine and sparse punctation; distance between punctures at least twice as wide as diameter of punctures; surface without microsculpture.

Front tibia with 9 spines at outer edge; two apical ones inserting on long teeth.

Aedeagus circular in shape with short smoothly curved apical part ending in an acute apex.

\section{Osorius intermedius ERICHSON, 1840: 754 (Figs 5 a-c)}

\section{Type material examined:}

Columbia: Bogota, without further data, 3 females (syntypes, ZMHU).

Additional material examined:

Columbia: Bogota, 1 specimen with remark 'tardus Dej. typ' (BMNH); Columbia, 2 specimens without further data, coll. Cameron (BMNH); Columbia, Rio Xena, col. Sharp ex Chevrolat, 1 specimen, leg. R. Rojas (BMNH); Columbia, 2 specimens, Mus. Drews (ZMUK); Cundinamarca, Finca San Pablo, 3 km N Alban (74.26' W, 4.52' N), 1800 m elevation, 8 specimens, 1-12. Aug. 1967, leg. P. \&. B. Wygodzinsky (AMNH, UIC).

\section{Diagnosis:}

The species is similar to $O$. brasiliensis in size and shape of the pronotum. The two species can hardly be differentiated without analysis of the aedeagus. Punctation and microsculpture are very similar, but elytral ground sculpture is slightly more distinct and surface, thus, less shiny in O. intermedius than in O. brasiliensis. The description of the pronotum as differentiating character given by ERICHSON (1839) can not be confirmed. The apical part of the aedeagus in $O$. intermedius resembles a thick hook, while it is acute and asymmetric in O. brasiliensis.

\section{Description:}

Length: 13.5 to $15.0 \mathrm{~mm}$. Colour: black.

Head: $2.0 \mathrm{~mm}$ long, $2.6 \mathrm{~mm}$ wide; punctation distinct and sparse; distance between punctures on average twice as wide as diameter of punctures; with few granular punctures between normal punctation, in particular, on clypeus; with deep round reticulate microsculpture; surface slightly shiny; clypeus with short, but widely obtuse prominences; with a long yellow seta at inner edge of prominences; front edge of clypeus largely emarginate; eyes not prominent; half as long as temples; behind eyes with few diagonal striae and a row of granular punctures.

Antennae with $3^{\text {rd }}$ antennomere 1.5 times longer than $2^{\text {nd }}$; antennomeres 4 to 6 slightly longer than wide; subsequent antennomeres quadrate.

Pronotum: $2.2 \mathrm{~mm}$ long, $2.8 \mathrm{~mm}$ wide; widest at front angles; slightly projecting to a short obtuse tooth; distinctly narrowed to posterior angles; with an indistinct emargination in front of posterior angles; lateral margin at front angles fine; distinctly widened to posterior angles; punctation distinct and varying in size; as dense as on head; distance between punctures on average twice as wide as diameter of punctures; a weak and sparse micro-punctation between normal punctation and scarcely visible in microsculpture; microsculpture netlike reticulate; weaker than on head, but surface less shiny; posterior edge margined; anterior prosternal process in lateral aspect with three granular punctures; anterior edge of process straight or slightly convex.

Elytra: $2.9 \mathrm{~mm}$ long, $3.0 \mathrm{~mm}$ wide; with moderately sparse punctation; weak coriaceous ground sculpture, and remains of netlike microsculpture; surface slightly shiny.

Aedeagus pear-shaped with hook-like apical part ending in a short acute apex. 
Osorius laevicollis BERNHAUER, 1908: 294 (Figs 17 a-c)

\section{Type material examined:}

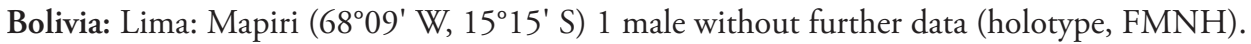

Additional material examined:

Ecuador: Sucumbios, Sacha Lodge $\left(76^{\circ} 27^{\prime} \mathrm{W}, 0^{\circ} 28^{\prime} \mathrm{S}\right)$, under bark, $270 \mathrm{~m}$ elevation, 1 specimen, 24.3.1999 and in fruit fall, 1 specimen, 23.3.1999 leg. R.W. Brooks (KU); Esmeraldas, Bilsa, 1 specimen, 5.6.1996, leg. P. Hibbs (KU); Peru: Loreto, Boqueron del Padre Abad, 470 m elevation, 13 specimens, 8.8.1946, leg. F. Woytkowski (AMNH, UIC); Junin, La Merced, Villa Rica Road (75¹8' W, $10^{\circ} 47^{\prime}$ S), flight intercept trap, 1450 m elevation, 1 specimen, 15.10 .1999 and $9.5 \mathrm{~km}$ NE Villa Rica Rd., $880 \mathrm{~m}$ elevation, 1 specimen, 15.10.1999, leg. R.W. Brooks (KU); Madre de Dios, Pantiacolla lodge $\left(71^{\circ} 16^{\prime}\right.$ W, $12^{\circ} 38^{\prime}$ S), 8 km NW El Mirador, under bark, 950 m elevation, 1 specimen, 24.10.2000, leg. R.W. Brooks (KU); Piura, Divisoria Huan, 1 specimen, 8.8.1946, leg. F. Woytkowski (AMNH); Ucayali, Aguaytia, 295 m elevation, 2 specimens, 15.9.1946, leg. F. Woytkowski (AMNH).

\section{Diagnosis:}

O. laevicollis is similar in size to $O$. dentatus, $O$. costaricensis and $O$. sublaevis, but is, on average, slightly larger than these species. The dense microsculpture and matte pronotal surface resembles that of $O$. costaricensis and $O$. sublaevis, but pronotal punctation is distinctly larger and denser. In contrast to $O$. costaricensis, the apex of the aedeagus is extremely acute and long.

\section{Description:}

Length: $7.8 \mathrm{~mm}$. Colour: black, legs and antennae reddish brown.

Head: $1.2 \mathrm{~mm}$ long, $1.5 \mathrm{~mm}$ wide; front edge laterad without prominence, but with a wide emargination centrally; punctation dense and moderately deep; on disc, distance between punctures shorter than diameter of punctures; with sparser punctation on clypeus; a small midline and an area above base of antennae impunctate; surface with very weak isodiametric microsculpture; shiny; with several supraocular granular setiferous punctures; with short longitudinal striae at temples behind eyes.

Antennae with $2^{\text {nd }}$ antennomere short and nearly circular; conical $3^{\text {rd }}$ antennomere only slightly longer than $2^{\text {nd }}$; antennomeres 4 to 10 increasing in width; $4^{\text {th }}$ antennomere quadrate; $10^{\text {th }}$ antennomere wider than long; relation length : width 0.77 .

Pronotum: $1.4 \mathrm{~mm}$ long, $1.6 \mathrm{~mm}$ wide; widest at anterior edge; sides slightly narrowed in anterior half; distad more distinctly narrowed and slightly emarginate in front of posterior, obtusely rounded angles; lateral margin narrow in anterior half, widened to posterior angles; punctation finer and distinctly sparser than on head; distance between punctures two to three times wider than diameter of punctures; a narrow midline impunctate, but with short central groove; surface with isodiametric microsculpture; slightly shiny.

Elytra: $1.7 \mathrm{~mm}$ long, $1.6 \mathrm{~mm}$ wide; with deep coriaceous ground sculpture; punctation present, but scarcely visible between deep ground sculpture; in spite of deep ground sculpture, surface shiny.

Abdomen with very sparse and fine punctation and weak, netlike microsculpture; surface shiny; tergites without setae.

Front tibia at outer edge with 9 spines; apical three ones inserting on short teeth.

Aedeagus oval in shape with extremely short apical part suddenly narrowed in front of acute apex. 
Osorius laevigatulus ScHUBERT, 1911: 4 (Figs $21 \mathrm{a}-\mathrm{b}$ )

Type material examined:

Brazil: Paraná, Porto Lucena $\left(55^{\circ} 01^{\prime} \mathrm{W}, 27^{\circ} 51^{\prime} \mathrm{S}\right), 1$ female, without further data (holotype, ZMHU).

Additional material examined:

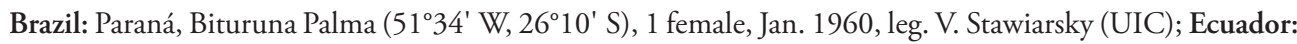
Sucumbios, Shushufindi $\left(76^{\circ} 38^{\prime} \mathrm{W}, 0^{\circ} 11^{\prime}\right.$ S), 1 female, 8.12.2004, leg. P. Banar (JC).

\section{Diagnosis:}

The species can be easily differentiated from most similar species in size by the total lack of microsculpture on head and pronotum, and by the polished surface. However, it is very similar to O. wasmanni in this respect. Pronotum in O. laevigatulus is less narrowed to posterior angles and density of punctation is more varying than in $O$. wasmanni. Unfortunately, only females could be found in the collections studied.

\section{Description:}

Length: $10.8 \mathrm{~mm}$. Colour: black, legs and antennae brown.

Head: $1.6 \mathrm{~mm}$ long, $2.0 \mathrm{~mm}$ wide; eyes as long as temples; front edge slightly emarginate; without distinct teeth at outer angles; disc with distinct and moderately dense punctation; distance between punctures partly shorter and partly wider than diameter of punctures; a circular spot with sparser punctation on disc; neck with distinctly denser punctation; with numerous supraocular striae and few granular punctures; surface without microsculpture; polished.

Antennae with $2^{\text {nd }}$ antennomere globular and short; only half as long as conical $3^{\text {rd }}$ one; subsequent antennomeres 5 and 6 distinctly longer than wide; antennomeres 8 to 10 quadrate.

Pronotum: $1.9 \mathrm{~mm}$ long, $2.2 \mathrm{~mm}$ wide; widest at anterior edge; sides in front half more or less parallel; distad more strongly narrowed to posterior edge; in front of posterior edge distinctly emarginate; anterior angles distinctly tooth-like prominent; posterior angles obtusely rounded; lateral edge margined; margin widened to posterior angles; posterior edge margined, anterior edge not margined; punctation deep, but moderately dense; distance partly shorter and partly wider than diameter of punctures; in particular at posterior angles, punctation sparser; with deeply longitudinal central furrow, nearly reaching front and posterior edges; additionally, indistinct transverse depressions in anterior and posterior half; surface without microsculpture; polished.

Elytra: $2.4 \mathrm{~mm}$ long, $2.3 \mathrm{~mm}$ wide; with weak, sparse and irregular punctation; distance between punctures on average much wider than diameter of punctures; surface more or less polished, but less shiny than pronotum as result of irregular coriaceous ground sculpture.

Front tibia with 9 spines at outer edge; 4 apical ones inserting in long teeth; subsequent 3 ones inserting in short teeth and last 2 ones inserting directly in outer edge.

Osorius morio NotMan, 1925: 18 (Figs 28 a-c)

\section{Type material examined:}

Mexico: Veracruz, Omealca $\left(96^{\circ} 45^{\prime}\right.$ W, $18^{\circ} 43^{\prime}$ N), 1 male, April 16, 1908, leg. F. Knab (holotype, NHMW).

Additional material examined:

Mexico: Pipiapan (950' W, $18^{\circ} 27^{\prime} \mathrm{N}$ ), carrion trap, 1 specimen, 15.2.1991, leg. Morón (KU); 4 km W 
Sontecompan (95 $\left.59^{\prime} \mathrm{W}, 18^{\circ} 30^{\prime} \mathrm{N}\right), 1$ specimen, 10.4.1966, leg. G.E. Ball (KU); Cordoba $\left(96^{\circ} 55^{\prime} \mathrm{W}\right.$, $\left.18^{\circ} 53^{\prime} \mathrm{N}\right), 1$ specimen, 12.6.1908 (AMNH); Oaxaca, Palenque (91 $\left.{ }^{\circ} 58^{\prime} \mathrm{W}, 17^{\circ} 29^{\prime} \mathrm{N}\right)$, under bark, $200 \mathrm{~m}$ elevation, 4 specimens, 24.4.1993, leg. R.W. Brooks (KU, UIC); Jalapa (92 $\left.48^{\prime} \mathrm{W}, 17^{\circ} 42^{\prime} \mathrm{N}\right)$, 9 specimens without date, leg. W. Schaus (AMNH); Veracruz $\left(96^{\circ} 16 \mathrm{~W}, 19^{\circ} 11 \mathrm{~N}\right)$, Las Cabanas, Monte Pio Veracruz, 19.1.1980, leg. Espinoza (UNAM).

\section{Diagnosis:}

O. morio is a medium-sized species without micro-punctation, but with dense microsculpture and matte surface. In this respect, it resembles a large number of species from which it can be hardly distinguished. Certain identification can be achieved only by a genital dissection. The apical part of the aedeagus is extremely long compared to the basal part. It ends in a thick, obtuse apex that is lighter in colour in comparison to the remaining aedeagus.

\section{Description:}

Length: $9.5 \mathrm{~mm}$. Colour: black; legs and antennae dark brown.

Head: $1.4 \mathrm{~mm}$ long, $2.0 \mathrm{~mm}$ wide; eyes small; shorter than temples; anterior half distinctly narrowed to front edge; anterior edge of clypeus undulate and with pair of broad teeth; in centre smoothly prominent; punctation dense and distinct; only at base of antennae impunctate; distance between punctures on average shorter than diameter of punctures; with several supraocular granular and setiferous punctures; with several short striae behind eyes; surface with weak isodiametric microsculpture, shiny; in addition to supraocular setiferous punctures, a pair of setae on disc at anterior edge of eyes, near neck, and at posterior edge of clypeus.

Antennae with $2^{\text {nd }}$ antennomere oval; conical $3^{\text {rd }} 1.5$ times longer than $2^{\text {nd }}$; antennomeres 4 and 5 slightly longer than wide; subsequent antennomeres increasing in length, but more or less quadrate.

Pronotum: $1.5 \mathrm{~mm}$ long, $2.1 \mathrm{~mm}$ wide; widest at anterior edge; anterior angles tooth-like prominent; sides in anterior half slightly narrowed, in posterior half strongly narrowed; slightly emarginate in front of posterior angles; lateral margin narrow shortly behind anterior tooth; distad widened and widest in front of posterior angles; punctation less dense than on head; distance between punctures on average as wide as or wider than diameter of punctures; a small impunctate midline with a short groove in posterior half; surface with weak netlike microsculpture, more distinct than on head and, thus, less shiny.

Elytra: $2.0 \mathrm{~mm}$ long, $2.0 \mathrm{~mm}$ wide; with coarse punctation; punctures distinctly larger than on pronotum; with weak coriaceous ground sculpture, and longitudinally striate in anterior half; surface shiny.

Aedeagus nearly triangular in shape with thick and long apical part ending in a thick obtuse apex which is lighter in colour than remaining aedeagus.

\section{Osorius nitens SHARP, 1876: 382 (Figs 35 a-c)}

O. simplex SHARP, 1876: 383 new synonymy

O. latimargo Bernhauer, 1908: 294 new synonymy

\section{Type material examined:}

Brazil: Amazonas: São Paulo de Olivença, 1 female without further data (syntype, BMNH); Amazonas, Tefé, 1 female without further data (holotype of $O$. simlex, BMNH); Peru: without further data, 2 females (syntypes of $O$. latimargo, FMNH). 
Additional material examined:

Brazil: Amapa, Sierra do Navio, sob cascas, 1 specimen, 5.12.1959, leg. R. Arlé (UIC); Ecuador: Sucumbios, Sacha Lodge $\left(76^{\circ} 5^{\prime} \mathrm{W}, 0^{\circ} 5^{\prime} \mathrm{S}\right)$, leg. Rougemont, 28.10 .2004 (RC, UIC); under bark, $270 \mathrm{~m}$ elevation, 4 specimens, 22.3.1999, leg. R.W. Brooks (KU); fruit fall, 1 specimen, 23.3.1999, leg. R.W. Brooks (KU); Napo, Jatun Sacha $\left(77^{\circ} 37^{\prime}\right.$ W, $1^{\circ} 03^{\prime}$ S), 16 km E Puerto Napo, rain forest, litter fall, 420 m elevation, 2 specimens, 27.2.2006 and 22.7.2009, leg. U. Irmler (UIC); $6.9 \mathrm{~km}$ E Puerto Napo (77 $43^{\prime} \mathrm{W}, 1^{\circ} 01^{\prime} \mathrm{S}$ ), primary forest with sparse understory, shady leaf litter, rotten branches, along trail, $500 \mathrm{~m}$ elevation, 1 specimen, 24.11.2006, leg. Fikácek (NMP); Yuturi Lodge (76 $\left.02^{\prime} \mathrm{W}, 0^{\circ} 32^{\prime} \mathrm{S}\right)$, under bark, $270 \mathrm{~m}$ elevation, 1 specimen, 21.3.1999, leg. R.W. Brooks (KU); Sierra Azul, Hazienda Aragon ( $77^{\circ} 55^{\prime}$ W, $0^{\circ} 40^{\prime}$ S), flight intercept trap, 2300 m elevation, 1 specimen, 26.3.1996, leg. R.W. Brooks (KU); Archidona (77²9' W, 054' S), $2.4 \mathrm{~km} \mathrm{~W}$, dense lowland vegetation on bank of stony river, wet leaf litter, sifted, $590 \mathrm{~m}$ elevation, 2 specimens, 21.11.2006, leg. Fikácek (NMP); Peru: Madre de Dios ( $\left.71^{\circ} 02^{\prime} \mathrm{W}, 12^{\circ} 20^{\prime} \mathrm{S}\right)$ Manu National Park, Cocha Otorongo, $310 \mathrm{~m}$ elevation, under bark, leg. R.W. Brooks, 9 specimens, 21.10.2000 (KU, UIC); Pentiacolla Lodge, Monk Saki trail, under bark, 400 m elevation, 1 specimen, 25.10.2000, leg. R.W. Brooks (KU); 2-7 km NW El Mirador trail, under bark, 1 specimen, 24.10.2000, leg. R.W. Brooks (KU); San Ramon (75⒈' W, $\left.11^{\circ} 03^{\prime} \mathrm{S}\right)$, Estancia Naranjal, $1000 \mathrm{~m}$ elevation, leg. B. Wygodzinski, 27.7.1965 (AMNH); Puerto Maldonado (69 $12^{\prime}$ W, $12^{\circ} 37^{\prime}$ S), Reserva Cuzco Amazonica, flight intercept trap, 1 specimen, 22.6.1989, leg. R. Leschen (KU); 15 km NE, under bark, 200 m elevation, 2 specimens, 17.6.1989 and 7.7.1989, leg. R. Leschen (KU); $15 \mathrm{~km} \mathrm{NE}$, fungusy log, 2 specimens, 6.7.1989, leg. R. Leschen (KU);

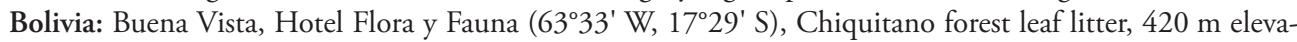
tion, 1 specimen, 5.11.2002, leg. R. Leschen (KU).

\section{Diagnosis:}

Compared to the similar species in size, the species can be distinguished by the shiny head and the scarcely shiny pronotum, but identification is difficult without genital dissection. Compared to similar species, the more or less circular shape of aedeagus is characterised by the acuminated, apical part with a distal narrow fold.

\section{Description:}

Length: $10.0 \mathrm{~mm}$. Colour: black.

Head: $1.5 \mathrm{~mm}$ long, $2.1 \mathrm{~mm}$ wide; with distinct but moderately sparse punctation; distance between punctures on average more than two times wider than diameter of punctures; isodiametric microsculpture very weak; surface nearly polished; clypeus with pair of obtuse lateral teeth carrying a long yellow seta on its inner side; labrum nearly two times wider than long; distinctly projecting clypeal front emargination; eyes $1 / 3$ as long as temples; dorsally and behind eyes with several striae; posterior striae pointing ventrally; with several granular supraocular punctures; lateral and ventral microsculpture distinct.

Antennae thick; $2^{\text {nd }}$ antennomere oval; $3^{\text {rd }}$ one conical and scarcely longer than $2^{\text {nd }}$; antennomeres 4 to 6 slightly longer than wide; subsequent antennomeres more or less quadrate.

Pronotum: $1.7 \mathrm{~mm}$ long, $2.2 \mathrm{~mm}$ wide; widest at acutely prominent front angles; narrowing continuously to posterior angles; lateral margin narrow at anterior angles; slightly wider at posterior angles; posterior edge margined; with coarser punctation than on head; distance between punctures on average as wide as diameter of punctures; a smooth midline impunctate; isodiametric microsculpture deep and much more distinct than on head; surface scarcely shiny.

Elytra: $2.4 \mathrm{~mm}$ long, $2.2 \mathrm{~mm}$ wide; with deeply coriaceous ground sculpture; punctation not visible between coarse ground sculpture; surface scarcely shiny due to deep ground sculpture.

Aedeagus more or less circular; with moderately long apical part ending in an acute apex; distad with a narrow fold. 
Osorius paganus sp. n. (Figs 14 a-c, 36 B, 38 D)

\section{Type material:}

Holotype, male: Columbia: Cundinamarca, Finca San Paulo, 3 km N Alban ( $74^{\circ} 26^{\prime}$ W, $4^{\circ} 52^{\prime}$ N), 1800 m elevation, 12.8.1967, leg. P. \& W. Wygodzinsky (AMNH).

Paratypes: 9 males, 12 females with same data as holotype (AMNH, UIC).

\section{Diagnosis:}

The species is very similar to O. venezuelanus. It can be differentiated from $O$. venezuelanus by the absence of clypeal teeth and less granular supraocular punctures. Moreover, microsculpture is deeper than in $O$. venezuelanus and, thus, surface matte and not as shiny as in $O$. venezuelanus. It also resembles $O$. costaricensis in the fine punctation of the pronotum. But, in O. costaricensis, few postocular striae are developed that are absent in O. paganus. Furthermore, ground sculpture of elytra is deeper in $O$. costaricensis, although surface is shinier than in $O$. paganus.

\section{Description:}

Length: $7.5 \mathrm{~mm}$. Colour: black.

Head: $1.0 \mathrm{~mm}$ long, $1.4 \mathrm{~mm}$ wide; with slightly prominent eyes; temples slightly narrowed behind eyes; sides of clypeus widely emarginate to anterior edge; anterior edge of clypeus with smooth emargination; lateral prominences divided by a depressed setiferous puncture; with two or three setiferous granular supraocular punctures; another setiferous granular puncture near neck and between clypeus and disc; with fine and sparse punctation, nearly invisible between deep netlike microsculpture; surface matte; laterad without striae.

Antennae with $2^{\text {nd }}$ antennomere oval; only slightly shorter than $3^{\text {rd }}$ antennomere; $3^{\text {rd }}$ antennomere conical; subsequent antennomeres slightly wider than $2^{\text {nd }}$ and $3^{\text {rd }}$ one; antennomeres 4 to 7 slightly longer than wide; penultimate antennomeres quadrate.

Pronotum: $1.4 \mathrm{~mm}$ long, $1.6 \mathrm{~mm}$ wide; widest at slightly prominent anterior angles; lateral margin narrow in anterior half; from middle to posterior angles widened; posterior angles obtusely rounded; with very indistinct depressions at posterior angles; a setiferous puncture near margin in posterior third; punctation fine and sparse; distance between punctures at least 3 to 4 times wider than diameter of punctures; with deep netlike microsculpture; surface matte.

Elytra: $1.7 \mathrm{~mm}$ long, $1.7 \mathrm{~mm}$ wide; with one setiferous puncture in posterior part, but without visible punctation; with fine coriaceous ground sculpture; surface as matte as on pronotum.

Abdomen without punctation, but with fine microsculpture; distinctly shinier than fore-body; last abdominal tergite nearly polished and with few setiferous punctures.

Aedeagus slightly elongate with extremely long straight apical part ending in an acute apex; apical part slightly asymmetric; pointing to right side.

\section{Etymology:}

The specific name derived from the same Latin word meaning "in the country".

\section{Osorius peruvianus BERNHAUER, 1908: 293 (Figs 23 a-d, 38 F)}

\section{Type material examined:}

Peru: 1 male, without further information (holotype, FMNH). 
Additional material examined:

Peru: Puerto Maldonado, $15 \mathrm{~km} \mathrm{NE}\left(69^{\circ} 03^{\prime} \mathrm{W}, 12^{\circ} 33^{\prime} \mathrm{S}\right)$, flight intercept trap, $200 \mathrm{~m}$ elevation, 2 specimens, 10.7.1989, leg. R. Leschen (KU); $15 \mathrm{~km} \mathrm{~N}$, Tambopata Prov, ex molassas, $200 \mathrm{~m}$ elevation, 2 specimens, 11.7.1989, leg. J.S. Ashe (KU); Madre de Dios, Pantiacolla lodge ( $\left.71^{\circ} 13^{\prime} \mathrm{W}, 12^{\circ} 39^{\prime} \mathrm{S}\right)$, Alto M. d. Dios River, 400 m elevation, 2 specimens, 26.10.2000, leg. R.W. Brooks (KU, UIC); Tingo Maria, Huan, 750 m elevation, 3 specimens, 19.5.1947 and 16.5.1947, leg. J. Pallister (AMNH); Brazil: Espirito Santo $\left(40^{\circ} 12^{\prime} \mathrm{W}, 20^{\circ} 05^{\prime} \mathrm{S}\right)$, Conceição da Barra, 1 specimen, 15.10.1972, leg. M. Alvarenga

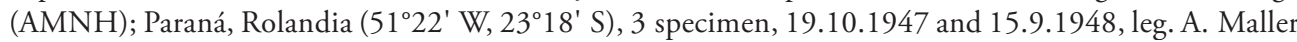
(AMNH).

\section{Diagnosis:}

The species is very similar to $O$. integer with regard to punctation and microsculpture of the fore body. $O$. peruvianus is slightly larger on average than $O$. integer. It is also similar in size to $O$. sablbergi, but pronotal microsculpture is weaker and surface, thus, shinier.

\section{Description:}

Length: 10.8 - $11.5 \mathrm{~mm}$. Colour: black.

Head: $1.5 \mathrm{~mm}$ long, $2.4 \mathrm{~mm}$ wide; with deep and dense punctation; distance between punctures on average as wide as or shorter than diameter; isodiametric microsculpture dense and deep; surface shiny; lateral angles of clypeus scarcely prominent and widely obtuse; front emargination short and smooth; labrum two times wider than long; scarcely projecting the clypeal emargination; eyes large, scarcely shorter than temples; with numerous striae dorsad to eyes and behind eyes; supraocular striae parallel, postocular ones diagonally pointing ventrad; with numerous granular punctures.

Antennae relatively thick; with $2^{\text {nd }}$ antennomere short, wider than long; $3^{\text {rd }}$ antennomere oval and more or less twice as long as $2^{\text {nd }}$; antennomeres 4 and 5 slightly longer than wide; subsequent antennomeres quadrate.

Pronotum: $2.1 \mathrm{~mm}$ long, $2.6 \mathrm{~mm}$ wide; widest at front edge; anterior angles tooth-like prominent; sides continuously narrowed to posterior angels; indistinct emargination shortly in front of posterior angles; lateral margin narrow at anterior angles; distinctly wider at posterior angles; posterior edge margined; punctation and microsculpture distinct and as deep as on head; surface shiny; in posterior half of smooth midline, a short longitudinal depression.

Elytra: $2.7 \mathrm{~mm}$ long, $2.7 \mathrm{~mm}$ wide; with coarse and dense punctation and indistinct coriaceous ground sculpture; surface shiny.

Aedeagus pear-shaped with moderately long apical part with obtuse apex and wide distal fold.

\section{Osorius piceus ERICHSON, 1840: 755 (Figs 29 a-c)}

\section{Type material examined:}

Brazil: 1 male, 1 female without further data (syntypes, ZMHU).

Additional material examined:

Brazil: 1 specimen, without further data (BMNH); Est. do Rio de Janeiro, Petropolis (43⒈ $\left.10^{\prime} \mathrm{W}, 22^{\circ} 31^{\prime} \mathrm{S}\right)$,

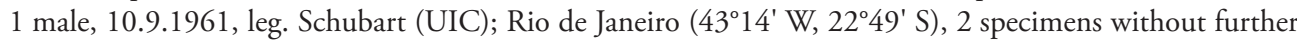

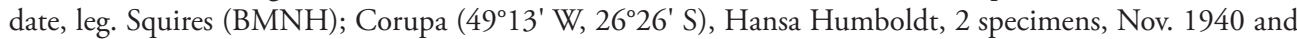

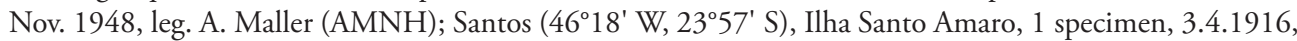
leg. G. Bryant (BMNH); Paraná, Antonina, 11.8 km NE, Res. Nat. do Rio Cachoeira, Sec. moist lowland 


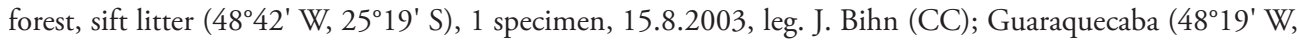
$25^{\circ} 17^{\prime}$ S), Reserva Serra do Itaqui, moist lowland forest, sift litter, Winkler sample, 3 specimens, 21.5.2007

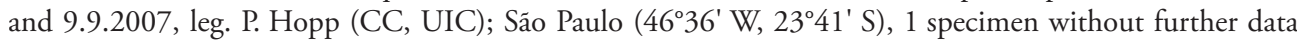
(AMNH).

\section{Diagnosis:}

The species can be differentiated from the similar species in size by the lighter coloured brown elytra when comparing it to the black elytra in all other species.

\section{Description:}

Length: $8.7 \mathrm{~mm}$. Colour: black; pronotum and elytra dark brown.

Head: $1.5 \mathrm{~mm}$ long, $1.8 \mathrm{~mm}$ wide; with dense and deep punctation; distance between punctures on average as wide as diameter of punctures; isodiametric microsculpture moderately deep; surface shiny; front edge of clypeus emarginate with undulate inner side of lateral teeth; with one long and several extremely short setae on each side of middle; labrum wider than long; lateral striae behind eyes short and weak; with several supraocular granular punctures.

Antennae with $2^{\text {nd }}$ antennomere oblong; $3^{\text {rd }}$ conical antennomere scarcely longer than $2^{\text {nd }}$; antennomeres 4 to 6 slightly longer than wide; subsequent antennomeres quadrate.

Pronotum: $1.7 \mathrm{~mm}$ long, $2.0 \mathrm{~mm}$ wide; sides widest at front angles, forming a short prominent tooth; more or less continuously narrowed to posterior angles; posterior edge margined; with punctation and microsculpture as on head; surface shiny; a fine and sparse micro-punctation between normal, coarse punctures.

Elytra: $2.2 \mathrm{~mm}$ long, $2.0 \mathrm{~mm}$ wide; with weak coriaceous ground sculpture, and sparse and fine punctation; surface shiny, nearly polished.

Aedeagus small and elongate with a short acute apical part.

\section{Osorius propinquus BERNHAUER, 1920: 138 (Figs 34 a-c)}

\section{Type material examined:}

Brazil: Espirito Santo, 1 male (holotype, FMNH).

\section{Diagnosis:}

The species resembles $O$. sablbergi, $O$. nitens, $O$. puncticeps, and $O$. confusus in size and punctation. Microsculpture in $O$. propinquus is much weaker than in $O$. sahlbergi, and surface is, thus, much shinier. Furthermore, the aedeagus of $O$. propinquus ends in an obtuse hook-like apex, whereas aedeagus of $O$. sahlbergi is flattened at apex. It is most similar to $O$. nitens in the shape of the pronotum. In $O$. confusus and $O$. puncticeps, the pronotum is more narrowed from anterior angles to posterior angles than in $O$. propinquus. It can be distinguished from $O$. nitens by the sparser and finer punctation of the pronotum.

\section{Description:}

Length: $10.5 \mathrm{~mm}$. Colour: black.

Head: $1.7 \mathrm{~mm}$ long, $2.3 \mathrm{~mm}$ wide; punctation deep and sparse; distance between punctures on average as wide as or distinctly wider than diameter of punctures; isodiametric microsculpture weak; surface shiny; disc at base of antennae impunctate and without microsculpture; surface polished; a transversal, oval space on posterior disc impunctate, but with weak microsculpture; 
clypeus with scarcely acute tooth-like lateral angles and central front emargination; labrum two times wider than long, not projecting front emargination; eyes $1 / 3$ as long as temples; with few short postocular striae and several supraocular granular punctures and at least two supraocular setae.

Antennae with $2^{\text {nd }}$ antennomere more or less circular; conical $3^{\text {rd }}$ antennomere slightly longer than $2^{\text {nd }}$; antennomeres 4 to 6 scarcely longer than wide; subsequent antennomeres quadrate.

Pronotum: $1.9 \mathrm{~mm}$ long, $2.4 \mathrm{~mm}$ wide; widest at tooth-like anterior angles; more or less continuously narrowed to posterior angles; lateral margin at anterior angles narrow; slightly wider at posterior edge; posterior edge margined; with sparse and moderately fine punctation; punctation on average finer and sparser than on head; distance between punctures on average two times wider than diameter of punctures; with very fine and sparse micro-punctation between normal punctures; isodiametric microsculpture weak; surface slightly shiny; with central indistinct longitudinal depression.

Elytra: $2.5 \mathrm{~mm}$ long, $2.4 \mathrm{~mm}$ wide; with deep and moderately dense punctation and weak coriaceous ground sculpture.

Aedeagus pear-shaped with short apical part ending in an obtuse slightly back-curved apex.

\section{Osorius puncticeps SHARP, 1887: 678 (Figs 33 a-c)}

\section{Type material examined:}

Mexico: Cordoba, 1 male, 1 female without further data (syntypes, BMNH).

\section{Additional material examined:}

Mexico: Mexico, 4 specimens without further data (BMNH, ZMUK); Mexico, 1 specimen, Eppelsheim Steind. without further data (AMNH); Veracruz, Jalapa $\left(92^{\circ} 48^{\prime} \mathrm{W}, 17^{\circ} 42^{\prime} \mathrm{N}\right), 1$ specimen without further data, leg. W. Schaus (AMNH); $1.1 \mathrm{~km} \mathrm{~S}$ on Coatepec road, under bark, $1280 \mathrm{~m}$ elevation, 6 specimens, 12.7.1992, leg. J.S. Ashe (KU, UIC); $2.3 \mathrm{~km} \mathrm{~S}$. Jalapa, forest litter, 1 specimen, $1320 \mathrm{~m}$ elevation, 1 specimen, 13.7.1990, leg. J.S. Ashe (KU); $1.7 \mathrm{~km} \mathrm{~W}$ Huatusco ( $\left.96^{\circ} 57^{\prime} \mathrm{W}, 19^{\circ} 08^{\prime} \mathrm{N}\right)$, under bark, $1250 \mathrm{~m}$ elevation, 3 specimens, 11.7.1990, leg. R. Leschen (KU); 7 km E Huatusco, Hwy 125, leaf litter/fruitfall, 1 specimen, 1230 m elevation, 16.7.1990, leg. J.S. Ashe (KU); Fortin de las Flores $\left(97^{\circ} 00^{\prime} \mathrm{W}, 18^{\circ} 90^{\prime} \mathrm{N}\right)$, 1 specimen, 2.1.1989, leg. Danforth (KU), Hidalgo, Tlanchinol $\left(98^{\circ} 65^{\prime} \mathrm{W}, 20^{\circ} 98^{\prime} \mathrm{N}\right), 4.4 \mathrm{~km} \mathrm{~N}$, Hwy 105, under bark, 1420 m elevation, 1 specimen, 6.7.1992, leg. J.S. Ashe (KU); San Luis Potosi, $3 \mathrm{~km}$ E Xilitla (913' W, 16 $\left.36^{\prime} \mathrm{N}\right)$, under bark, $600 \mathrm{~m}$ elevation, 3 specimens, 6.7., 7.7. and 9.7.1990, leg. J.S. Ashe (KU); Tlamaya (nr. Xilitla), 1 specimen, 24.8.1988, leg. D. Yanega (KU); Chiapas, Lago de Montebello ( $\left.91^{\circ} 40^{\prime} \mathrm{W}, 16^{\circ} 06^{\prime} \mathrm{N}\right)$, Cinco Lagos, Liquidamber oak pine forest litter, $1500 \mathrm{~m}$ elevation, 1 specimen, 22.9.1992, leg. R. Anderson (KU); Misantla (96 $\left.51.0 \mathrm{~W}, 19^{\circ} 56.4 \mathrm{~N}\right)$, Salvador Díez Mirón, Bosque mesófilo de montana, 2 specimens, 17.04.1999, 05.07.1997, leg. J. Marquez (UNAM); Cordoba $\left(96^{\circ} 55 \mathrm{~W}, 18^{\circ} 53 \mathrm{~N}\right)$, Camino a Plan de Ayala, Loma Chica, Bosque mesófilo de montana, ex tronco caido, $1330 \mathrm{~m}$ elevation, 3 specimens, 17.04.1999, leg. J. Marquez (UNAM); Xicotepec de Juárez $\left(97^{\circ} 57.29 \mathrm{~W}, 20^{\circ} 16.32 \mathrm{~N}\right)$, Hydroeléctrica Patla, Selva mediana, ex troncos caidos, $460 \mathrm{~m}$ elevation, 1 specimen, 5.10.2002, leg. J. Marquez (UNAM); Huayacocotla $\left(98^{\circ} 23.31 \mathrm{~W}, 20^{\circ} 41.13 \mathrm{~N}\right)$, San Antonio, Bosque mesófilo de montana, en tronco, 2 specimens, 17.10.2006, leg. J. Marquez (UNAM); Xilitla $\left(98^{\circ} 59 \mathrm{~W}, 21^{\circ} 22 \mathrm{~N}\right)$, San Luis Potosi, Las Pozas de James, Selva mediana, en troncos con hongos, $585 \mathrm{~m}$ elevation, 1 specimen, 18.07.2007, leg. J. Marquez (UNAM); Hidalgo, Tamaulipas ( $98^{\circ} 55.50 \mathrm{~W}$, $\left.21^{\circ} 09.56 \mathrm{~N}\right)$, Chapulhuacán, Bosque mesófilo de montana, troncos podridos, 3 specimens, 3.7.2003, leg. J. Marquez (UNAM). 


\section{Diagnosis:}

The species is very similar to $O$. nitens, $O$. propinquus, and $O$. confusus. It can be distinguished from $O$. nitens and $O$. propinquus by the more narrowed pronotum, with the front edge more than 1.3 times wider than the posterior edge. Compared to $O$. confusus the distinct longitudinal stria is absent and the apical part of the aedeagus is much longer.

\section{Description:}

Length: $11.0 \mathrm{~mm}$. Colour: black, tarsi and antennae dark red.

Head: $1.80 \mathrm{~mm}$ long, $2.30 \mathrm{~mm}$ wide; short eyes not prominent; temples twice as long as eyes; front edge of clypeus with an obtuse, wide prominence at each outer angle and in central part; lateral prominence denticulate and with short setae; punctation distinct and irregularly dense; partly coriaceous, but on average distance between punctures half as wide as diameter of punctures; a fine micro-punctation present; impunctate at base of antennae and a small space on posterior disc; partly with very weak, netlike microsculpture; surface polished.

Antennae with $1^{\text {st }}$ antennomere as long as four subsequent ones; $2^{\text {nd }}$ antennomere short and oblong, half as long as conical $3^{\text {rd }}$ one; subsequent four antennomeres increasing in width, but still longer than wide; antennomeres 8 to 10 quadrate.

Pronotum: $1.90 \mathrm{~mm}$ long, $2.50 \mathrm{~mm}$ wide; widest at anterior angles forming a short prominent tooth; distad distinctly narrowed; lateral margin narrow at anterior angle; distinctly broadened to posterior angles; punctures deep and larger than on head, but of similar density; on average, distance between punctures half as wide as diameter of punctures; at anterior edge and along smooth impunctate midline with finer and sparser punctation; with weak, netlike microsculpture, but surface polished.

Elytra: $2.30 \mathrm{~mm}$ long, $2.45 \mathrm{~mm}$ wide; with deep coriaceous ground sculpture; irregular rows of punctures scarcely visible; punctures more distinct at sides and ground sculpture weaker.

Aedeagus is nearly circular with a long acuminate apical part.

Osorius pusillus n. sp. (Figs 16 a-c, 36 D, 38 E)

\section{Type material:}

Holotype, male: Peru: Huanuco, Panguana (74²56' W, 9³7' S), male, 18.2.1984, leg. M. Verhaagh, rain forest, \#Pwa 6 (UIC).

Paratypes: 1 female, 1 male, rain forest, 21.1. - 18.2.1984, leg. M. Verhaagh (UIC).

\section{Diagnosis:}

This is the smallest species of the Neotropical Osorius known. It is smaller than O. venezuelanus, but resembles that species in the microsculpture of the pronotum and the numerous granulate supraocular punctures. In contrast to O. venezuelanus, a second distinct tooth is not developed at front edge of clypeus in $O$. pusillus.

\section{Description:}

Length: $6.0 \mathrm{~mm}$. Colour: black; antennae reddish; femur dark red; tibia and tarsi lighter red.

Head: $0.8 \mathrm{~mm}$ long, $1.1 \mathrm{~mm}$ wide; eyes not prominent; sides in front of eyes slightly emarginate to front angles of clypeus; anterior edge of clypeus widely emarginate and with a pair of short teeth; with granular punctures and striae on a supraocular and postocular space; two 
supraocular setiferous punctures; two setiferous punctures on each side of central disc and several setiferous punctures on clypeus; three preocular setiferous punctures; discal setae long, clypeal setae short; punctation irregularly dense; a central space near neck, a space at base of antennae and at front margin of clypeus impunctate; discal punctures large, but not deep; with dense micro-reticulation; microsculpture indistinct; surface shiny.

Antennae slightly longer than head; with $2^{\text {nd }}$ antennomere oblong; $3^{\text {rd }}$ antennomere conical and not longer than $2^{\text {nd }}$; subsequent antennomeres increasing in width; $4^{\text {th }}$ antennomere longer than wide; subsequent antennomeres more or less quadrate.

Pronotum: $1.1 \mathrm{~mm}$ long, $1.25 \mathrm{~mm}$ wide; widest at anterior angles; anterior angles tooth-like and prominent; lateral margin narrow at anterior angles, widened in posterior half; posterior angles widely rounded in an obtuse angle; punctation distinct; distance between punctures on average as wide as or slightly wider than diameter of punctures; an impunctate midline throughout total length; a setiferous puncture in posterior third; distance of puncture to lateral margin shorter than to posterior margin; isodiametric microsculpture more distinct than on head, but still not deep; surface shiny.

Elytra: $1.3 \mathrm{~mm}$ long, $1.3 \mathrm{~mm}$ wide; with coriaceous ground sculpture; sparse punctation; nearly invisible in deep ground sculpture.

Abdomen nearly impunctate; only with few setiferous punctures; isodiametric microsculpture moderately deep; surface as shiny as on pronotum.

Aedeagus pear-shaped with moderately long apical part ending in an obtusely acuminate apex.

\section{Etymology:}

The specific name derives from the same Latin word and refers to the small size of the species.

\section{Osorius sablbergi BERNHAUER, 1920: 137 (Figs 31 a-c)}

\section{Type material examined:}

Brazil: Rio de Janeiro, Petropolis ( $43^{\circ} 10^{\prime}$ W, 22 $2^{\circ} 31^{\prime}$ S), 2 males, 1 female, Dec. 1850, leg. Sahlberg (syntypes, FMNH).

\section{Additional material examined:}

Brazil: without further data (IRSNB); Rio de Janeiro ( $43^{\circ} 14^{\prime} \mathrm{W}, 22^{\circ} 49^{\prime}$ S), Caminho do Bico do Papagaio, 3 specimens, 16.12.1959, leg. H. Schubart (UIC); Rio de Janeiro, 1 specimen without further data (IRSNB); Floresta da Tijuca, 1 specimen, 17.3.1962, leg. Th. Becker (UIC); Itatiaia ( $43^{\circ} 43^{\prime}$ W, 22 $42^{\prime}$ S), E. of Rio

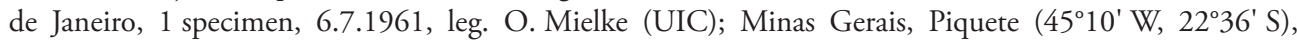
D. Morcina, 1500 m elevation, 2 specimens, 1.10.1957, leg. R. Arlé; 1 specimen, 5.1.1960, leg. R. Arlé and Schubart, H. (UIC); São Paulo, Campos de Jordão, 103 specimens, 15.7.1957, leg. K. Lenko (AMNH).

\section{Diagnosis:}

The species is characterised by the prominent lateral angles of the clypeus, which are similar to those in O. ater. O. sablbergi is distinctly smaller, and lateral teeth of clypeus less prominent and more obtuse at apex. The aedeagus is characterised by the obtuse emarginate apex that is similar to the aedeagus of $O$. ashei, but the apical part of the aedeagus in $O$. ashei is longer than in O. sahlbergi.

\section{Description:}

Length: 10.5 - $11.0 \mathrm{~mm}$. Colour: black. 
Head: $2.0 \mathrm{~mm}, 2.2 \mathrm{~mm}$ wide; punctation distinct, distance between punctures as wide as or shortly wider than diameter of punctures; with isodiametric microsculpture; surface slightly shiny; clypeus with distinctly prominent front angles; more or less obtuse at apex, at inner side of lateral prominences with a long seta; labrum slightly emarginate in centre; not projecting clypeal emargination; disc at antennal base shiny; eyes relatively large; nearly as long as temples; few postocular striae and granular punctures.

Antennae with $2^{\text {nd }}$ antennomere short, as long as wide; $3^{\text {rd }}$ conical and slightly longer than $2^{\text {nd }}$; antennomeres 4 to 6 slightly longer than wide; subsequent antennomeres quadrate.

Pronotum: $1.9 \mathrm{~mm}$ long, $2.3 \mathrm{~mm}$ wide; punctation and microsculpture similar to head; with a short, longitudinally depressed midline; widest at front angles; continuously narrowed to posterior angles; front angles acute with a prominent tooth; lateral margin narrow at front angles, distad widened to posterior angles; front edge without margin, posterior edge with distinct margin.

Elytra: $2.5 \mathrm{~mm}$ long, $2.3 \mathrm{~mm}$ wide; surface shiny, with deep and sparse punctures, surface coriaceously sculptured.

Aedeagus pear-shaped with short and broad apical part ending in a flattened concave apex.

\section{Osorius sinuatocollis BERNHAUER, 1920: 139 (Figs 19 a-b)}

\section{Type material examined:}

Brazil: 1 female without further data (holotype, FMNH).

\section{Diagnosis:}

The species is easy to distinguish, because of the characteristic shape of the pronotum with the deep emargination in front of the posterior angles. Unfortunately, only the female type specimen could be studied.

\section{Description:}

Length: $10.5 \mathrm{~mm}$. Colour: black.

Head: $1.5 \mathrm{~mm}$ long, $2.2 \mathrm{~mm}$ wide; punctation moderately dense and deep; on clypeus with very few indistinct punctures; partly with dense and coriaceous punctation on disc; a small circular depressions on central disc and at antennal base impunctate; punctate space with isodiametric microsculpture; surface slightly shiny; clypeus with obtusely prominent angles; labrum relatively long; labrum distinctly projecting clypeal emargination; eyes slightly shorter than temples; with supraocular and postocular striae and granular punctures; striae behind eyes pointing ventrad; with several supraocular setae.

Antennae elongate with $3^{\text {rd }}$ antennomere conical and nearly two times longer than $2^{\text {nd }}$; antennomeres 4 to 6 longer than wide; subsequent antennomeres quadrate.

Pronotum: $2.0 \mathrm{~mm}$ long, $2.4 \mathrm{~mm}$ wide; widest at tooth-like prominent front angles; continuously, but only slightly narrowed behind front angles; in posterior third distinctly emarginate; posterior angles nearly rectangular; lateral margin at front angles narrow; distinctly wider at posterior angles; posterior edge margined; punctation moderately dense and deep; distance between punctures on average as wide as diameter of punctures; with weak isodiametric microsculpture; surface shiny; a long longitudinal depression within smooth midline; with longer distance from front edge than from posterior edge. 
Elytra: $2.3 \mathrm{~mm}$ long, $2.4 \mathrm{~mm}$ wide; with coriaceous ground sculpture; moderately dense and deep punctation scarcely visible between deep ground sculpture.

\section{Osorius stipes SHARP, 1876: 382 (Figs 2 a-c)}

\section{Type material examined:}

Brazil: Amazonas: Téfé 1 male (syntype, BMNH).

Additional material examined:

Brazil: Tefé, 3 specimens leg. M. de Mathan, 1. Trimestre 1879 (BMNH); Manaus, Reserva Ducke, 14.3.1971 and 9.6.1971, leg. U. Irmler, collected under bark (UIC), 26.7.1973, leg. R.T. Schuh (AMNH); Ilha Itacoai, 1 specimen, 6.1950, leg. J.C.M. Carvalho (UIC); Manaus, Nov. 1961. leg. R. Arlé (UIC); Benjamin Constante $\left(70^{\circ} 02^{\prime} \mathrm{W}, 4^{\circ} 22^{\prime} \mathrm{S}\right)$, Rio Javary, 1 specimen, 15.3 .1942 . leg. A. Rabaut (AMNH); Cearà; Pebas (71 $\left.49^{\prime} \mathrm{W}, 3^{\circ} 10^{\prime} \mathrm{S}\right)$, 1 specimen (IRSNB); Pará, 1 male, 1 female, without further data

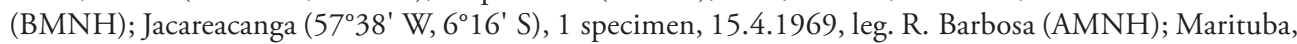
Ananindeua (48 22' W, $\left.1^{\circ} 22^{\prime} \mathrm{S}\right), 1$ specimen, 15.11.1963, leg. Wygodzinski (AMNH); Mato Grosso: May 1947, leg. J.C.M. Carvalho (UIC); French Guiana: Saül, Les Eaux Clairs, fig fruit fall, 1 specimen, 13.10.1995, leg. L. Herman (AMNH); Guyana: Kartabo (57³7' W, 547' N), 16.8.1922, leg. W. Beebe (AMNH); Peru: Iquitos $\left(73^{\circ} 11^{\prime} \mathrm{W}, 3^{\circ} 45^{\prime} \mathrm{S}\right)$, lowland forest, Rio Napo, Rio Sucusari, 1 specimen, 12.1998, leg. M.V. Bracley (BMNH); 1 specimen without further data (IRSNB).

\section{Diagnosis:}

The species can be distinguished from similarly sized species by the deep, long and numerous supraocular striae. In contrast to the remarks given by SHARP (1876), size is variable and not differing from the related species. It can not be distinguished from $O$. alternans without study of the aedeagus. The aedeagus in O. stipes is long with an acute apex, whereas the aedeagus in $O$. alternans is shorter and the apex is obtuse and shortly curved.

\section{Description:}

Length: 12 - 17 mm. Colour: black.

Head: $3 \mathrm{~mm}$ long, $3.8 \mathrm{~mm}$ wide; distinct and moderately sparse punctation; distance between punctures slightly wider than diameter of punctures; netlike reticulate microsculpture distinct; surface dull; anterior edge of clypeus distinctly denticulate; laterad with dense granular punctation; with several longitudinal supraocular and postocular striae behind eyes; disc with a pair of indistinct circular depressions; in lateral aspect, in front of eyes with three granular setiferous punctures; supraocular space with many granular setiferous punctures.

Antennae: with $3^{\text {rd }}$ antennomere slightly longer than $2^{\text {nd }}$; antennomeres 4 to 6 more or less quadrate; subsequent antennomeres slightly wider than long.

Pronotum: $2.8 \mathrm{~mm}$ long, $3.9 \mathrm{~mm}$ wide; distinct, but moderately dense punctation; distance between punctures on average two times wider than diameter; anterior angle denticulate and prominent; isodiametric microsculpture distinct; surface dull.

Elytra: $3.7 \mathrm{~mm}$ long, $3.9 \mathrm{~mm}$ wide; with numerous, coriaceous, longitudinal striae.

Aedeagus pear-shaped with a moderately long apical part ending in an acute apex. 
Osorius sublaevis, BERNHAUER, 1920: 9 (Figs 18 a-c)

\section{Type material examined:}

Paraguay: 1 male, without further data, leg. C. Bruch (holotype, FMNH).

\section{Diagnosis:}

$O$. sublaevis can be distinguished from the similarly smaller-sized $O$. costaricensis, $O$. verhaaghi and $O$. paganus by the denser and deeper punctation on the pronotum. The species most distinctly resembles $O$. laevicollis in size and punctation of the pronotum, but anterior angles in $O$. sublaevis are acuminate, whereas they are obtuse in O. laevicollis. Apical part of aedeagus in O. sublaevis is widely curved, whereas it is shortly curved in O. laevicollis.

\section{Description:}

Length: $7.5 \mathrm{~mm}$. Colour: black; legs light red.

Head: $1.2 \mathrm{~mm}$ long, $1.5 \mathrm{~mm}$ wide; sparse but distinct punctation; distance between punctures on average two times wider than diameter of punctures; isodiametric ground sculpture distinct; surface dull; front edge of clypeus obtusely prominent; on inner side with one setiferous puncture; eyes not prominent; several setae in front of eyes, two supraocular setae, and one seta between postocular seta and neck.

Antennae with $3^{\text {rd }}$ antennomere slightly longer than $2^{\text {nd }} ; 4^{\text {th }}$ and $5^{\text {th }}$ antennomeres slightly longer than wide; subsequent antennomeres globular.

Pronotum: $1.5 \mathrm{~mm}$ long, $1.7 \mathrm{~mm}$ wide; distinctly narrowed from front angles to posterior angles, and with narrow lateral margin; margin at posterior angles nearly as wide as at anterior angles; front angles distinctly tooth-like prominent; punctation considerably finer than on head; distance between punctures on average at least three times wider than diameter of punctures; with wide smooth midline in posterior half; isodiametric ground sculpture distinct; similar as on head and also with dull surface.

Elytra: $1.5 \mathrm{~mm}$ long, $1.6 \mathrm{~mm}$ wide; with coriaceous surface; punctures scarcely visible; surface moderately shiny; distinctly shinier than on head and pronotum.

Abdominal tergites nearly impunctate; except one lateral seta on each abdominal tergite.

Front legs at apical outer margin with three longer spines followed by three shorter spines; an additional apical tooth pointing outwards.

Aedeagus elongate with a long apical part ending in an acute apex.

Osorius tschirnhausi sp. n. (Figs 25 a-d, 37 B)

\section{Type material:}

Holotype, male: Venezuela: Maracay $\left(67^{\circ} 35^{\prime} \mathrm{W}, 10^{\circ} 14^{\prime} \mathrm{N}\right)$, Parque National, coastal mountains, male, 26.3.1998, M. v. Tschirnhaus (UIC).

Paratypes: 1 male, 1 female with same data as holotype (UIC); Aragua, Rancho Grande Biol. Stn., Portachelo Pass (67.41 W, 10.21 N), 1100 m elevation, 1 female, 14.5.1998, leg. J.S. Ashe, R. Brooks \& R. Hanley, \# VEN1ABH98, 037, collected in sifted leaf litter near creek (KU). 


\section{Diagnosis:}

The species can be easily identified by the conspicuous shape of the clypeus with a pair of long, second teeth mediad to the normal pair of broad lateral prominence. The aedeagus is similar to $O$. continentalus, $O$. boops, and $O$. wasmanni in its slender shape and resembles, in particular, that of $O$. continentalus.

\section{Description:}

Length: 9.5 - $10.0 \mathrm{~mm}$. Colour: black.

Head: $1.3 \mathrm{~mm}$ long, $1.7 \mathrm{~mm}$ wide; eyes slightly prominent; sides of clypeus in front of eyes deeply emarginate; thus, angles of clypeus nearly rectangular; front edge of clypeus with a pair of broad, obtuse teeth and mediad a second pair of more acute teeth; punctation irregularly dense; lateral parts of clypeus densely punctate; distance between punctures on average half as wide as diameter of punctures; on disc, distance between punctures at least twice as wide as diameter of punctures; with numerous supraocular granular setiferous punctures; neck very densely, nearly coriaceously punctate; with dense isodiametric microsculpture; surface slightly shiny.

Antennae with $2^{\text {nd }}$ antennomere globular; $3^{\text {rd }}$ conical antennomere nearly twice as long as $2^{\text {nd }}$, subsequent antennomeres only slightly increasing in width and, at least, slightly longer than wide.

Pronotum $1.8 \mathrm{~mm}$ long, $2.2 \mathrm{~mm}$ wide; widest at anterior acute angles; continuously narrowed in a smooth curve to posterior angles; shortly in front of posterior angles a distinct emargination; lateral margin narrow in anterior half and distinctly widened at posterior emargination; punctation as deep as on head, but more regularly dense; distance between punctures on average as wide as diameter of punctures and only in few parts with wider punctation; at posterior angles a finer and denser punctation; microsculpture similar to head; surface slightly shiny.

Elytra: $2.4 \mathrm{~mm}$ long, $2.2 \mathrm{~mm}$ wide; with coriaceous ground sculpture and with indistinct sparse punctation.

Aedeagus elongate with a discontinued, long apical part ending in an acute apex.

\section{Etymology:}

The species is dedicated to its collector Dr. Michael von Tschirnhaus, Bielefeld, Germany, who kindly collected this species for my studies even though he is mainly interested in flies.

Osorius venezuelanus sp. n. (Figs 15 a-c, 36 C)

\section{Type material:}

Holotype, male: Venezuela: Lara Sanare, 14.4 km SE. Yacambu N.P. (942'22" N, 69³4'42" W), 1500 m elevation, male, 16 May 1998, leg. R. Anderson, \#VEN1A98 012D, collected in cloud forest litter (KU).

Paratypes: 1 male, 2 females with same data as for holotype (KU, UIC).

\section{Diagnosis:}

The species is similar to $O$. costaricensis in size and isodiametric microsculpture of pronotum. $O$. venezuelanus is on average even slightly smaller than $O$. costaricensis. O. venezuelanus can be distinguished from $O$. costaricensis by the specific shape of the clypeal front edge. The large inner 
tooth of the lateral prominence resembles the structure in $O$. tschirnhausi, and looks bidentate in dorsal aspect. Moreover, the aedeagus of $O$. venezuelanus is much narrower than the aedeagus of $O$. costaricensis and resembles that of $O$. tschirnhausi.

\section{Description:}

Length: $6.2-6.5 \mathrm{~mm}$. Colour: black.

Head: $0.8 \mathrm{~mm}$ long, $1.2 \mathrm{~mm}$ wide; eyes not prominent and slightly shorter than temples; front edge of clypeus with broad lateral denticulate prominence; gap between outer tooth and inner teeth deep and wide and with a setiferous puncture; emargination between lateral prominences more or less straight; punctation on disc much sparser than laterad; on disc, distance between punctures as wide as or wider than diameter of punctures; laterad, punctation much denser, partly coriaceous; a large supraocular space with numerous granular punctures; isodiametric microsculpture distinct; surface slightly shiny.

Antennae with oval $2^{\text {nd }}$ antennomere and conical $3^{\text {rd }}$ antennomere; equal in size; subsequent antennomeres increasing in width; penultimate antennomeres more or less quadrate.

Pronotum: $1.25 \mathrm{~mm}$ long, $1.4 \mathrm{~mm}$ wide; widest at tooth-like prominent front angles; sides continuously narrowed from anterior to posterior angles; only indistinctly emarginate in front of posterior angles; lateral margin narrow in anterior half; distinctly widened in posterior half; punctation moderately dense and deep; distance between punctures on average as wide as diameter of punctures; posterior half of midline without punctures; isodiametric microsculpture distinct, as on head; surface slightly shiny.

Elytra: $1.5 \mathrm{~mm}$ long, $1.4 \mathrm{~mm}$ wide; with distinct punctation; punctures on average slightly larger than on pronotum, but sparser; distance between punctures on average two times wider than diameter of punctures; isodiametric microsculpture dense and deep, more distinct than on head; surface less shiny than on pronotum.

Aedeagus elongate; long apical part laterally depressed and ending in an obtuse apex.

\section{Etymology:}

The species name derives from the country's name where it was collected.

Osorius verhaaghi sp. n. (Figs 13 a-c, 36 A)

\section{Type material:}

Holotype, male: Peru: Huanuco, Panguana (7456' W, 9³7' S), male, 26.5. - 3.6.1984, leg. M. Verhaagh, collected by pitfall trap (UIC).

Paratype: female collected in rain forest, Aug-Sept. 1975, leg. W. Hanagarth (UIC).

\section{Diagnosis:}

$O$. verhaaghi can be easily identified by the shape and surface of the pronotum. The lateral margin, visible throughout its total length, and the deep microsculpture, producing a matte surface, is characteristic for the species. Eyes are slightly prominent, but less prominent than in $O$. boops and $O$. affinis. In contrast to $O$. boops, the clypeus and the lateral sides of pronotum are less emarginate in $O$. verhaaghi. Furthermore, the pronotal surface is slightly shiny in $O$. boops, but matte in $O$. verhaaghi. 


\section{Description:}

Length: $6.5 \mathrm{~mm}$. Colour: dark brown.

Head: $0.8 \mathrm{~mm}$ long, $1.4 \mathrm{~mm}$ wide; eyes slightly prominent; sides in front of eyes deeply emarginate; front edge of clypeus slightly emarginate; without distinct lateral prominences; with several supraocular granular punctures; punctation on disc moderately deep and dense; on average, distances between punctures as wide as or shorter than diameter of punctures; a granular setiferous puncture near posterior edge of eyes and another mediad one; setae extremely long; isodiametric microsculpture deep and dense; surface matte.

Antennae as long as head and half of pronotum combined; with $2^{\text {nd }}$ antennomere oblong; approximately twice as long as wide; $3^{\text {rd }}$ antennomere nearly twice as long as $2^{\text {nd }}$; subsequent antennomeres increasing in width; $4^{\text {th }}$ antennomere still longer than wide; subsequent antennomeres more or less quadrate.

Pronotum: $1.3 \mathrm{~mm}$ long, $1.5 \mathrm{~mm}$ wide; widest at anterior angles; anterior angles slightly projecting into a short tooth; sides straightly narrowed to obtusely rounded posterior angles; without emargination in front of posterior angles; lateral margin narrow and visible throughout total length in dorsal aspect; widened only in posterior third; punctation distinctly finer and sparser than on head; distance between punctures on average at least twice as wide as diameter of punctures; a setiferous puncture in posterior third near lateral margin and two further setiferous punctures near anterior angles; isodiametric microsculpture dense and deep; surface matte.

Elytra: $1.6 \mathrm{~mm}$ long, $1.5 \mathrm{~mm}$ wide; with almost rectangular shoulders forming slightly prominent angles; punctation deep and partly coriaceous, but still individual punctures visible; distance between punctures at least three times wider than diameter of punctures; isodiametric microsculpture dense, but less deep than on pronotum; surface slightly shiny.

Abdomen with very fine and sparse punctation and microsculpture; surface shiny.

Aedeagus elongate with a long, laterally depressed apical part ending in an obtuse apex.

\section{Etymology:}

The species is dedicated to its collector Dr. M. Verhaagh, who collected the species during his research on ants in Panguana, Peru.

\section{Osorius wasmanni BERNHAUER, 1920: 138 (Figs 22 a-c)}

\section{Type material examined:}

Brazil: Rio de Janeiro, Colonia alpina, 1 male, without further date, leg. Göldi (holotype, FMNH).

\section{Additional material examined:}

Brazil: Guaraquecaba ( $48^{\circ} 19^{\prime} 33 \mathrm{~W}, 25^{\circ} 17^{\prime} 54 \mathrm{~S}$ ), Reserva Serra do Itaqui, moist lowland forest, sift litter, Winkler sample, 2 males, 9.9.2007 and 21.5.2007, leg. P. Hopp (CC, UIC).

\section{Diagnosis:}

The species can be differentiated from similar species in size by the coarsely punctate pronotum with polished surface. In the similar $O$. dentatus, a weak microsculpture is visible on the pronotum. 


\section{Description:}

Length: $9.5 \mathrm{~mm}$. Colour: black.

Head: $1.6 \mathrm{~mm}$ long, $2.0 \mathrm{~mm}$ wide; coarsely and densely punctate; partly with coriaceous punctation; distance between punctures on average half as wide as diameter of punctures; isodiametric microsculpture distinct; surface shiny; a small space on disc at antennal base and on posterior portion without punctures and polished surface; front edge of clypeus with a pair of stout lateral teeth and with flat emargination between; eyes moderately long; slightly shorter than temples; with supraocular and postocular striae; postocular striae pointing ventrad; with several supraocular granular punctures and two supraocular setae.

Antennae more or less elongate; $2^{\text {nd }}$ antennomere oblong; $3^{\text {rd }}$ conical, scarcely longer than $2^{\text {nd }}$; antennomeres 4 to 6 longer than wide; subsequent antennomere more or less quadrate.

Pronotum: $1.9 \mathrm{~mm}$ long, $2.1 \mathrm{~mm}$ wide; widest at tooth-like front angles; continuously narrowed to posterior angles; an indistinct emargination shortly in front of posterior angles; lateral margin narrow at front angles and slightly widened to posterior angles; posterior edge margined; with coarse and dense punctation; distance between punctures much smaller than diameter of punctures; a fine micro-punctation between normal coarse punctation; without ground sculpture; surface polished; a long longitudinal furrow within smooth midline nearly extending from front edge to posterior margin.

Elytra: $2.2 \mathrm{~mm}$ long, $2.1 \mathrm{~mm}$ wide; with deep coriaceous ground sculpture; punctation scarcely visible between ground sculpture; surface shiny.

Aedeagus elongate with extremely long sinusoidal, apical part ending in an acute apex.

\section{Comments to ecology and geographic distribution}

Most of the specimens studied, particularly those from older collections, provide no labelled information of their habitat. Several specimens were collected by light traps or flight intercept traps, which also provide no further ecological information. Only a small number of specimens were labelled sufficiently enough to derive rough impressions of their habitat. These are expressions such as the following: under bark, rotten log, decayed log, fungous log, or litter near stream, forest litter, misc. mushrooms, and gilled mushrooms. According to this information, Osorius species seem to live in dead wood under bark, in forest litter, or in mushrooms. My own observations in Ecuador and Brazil support this thesis. These Osorius specimens originated from dead wood that was soft and already strongly decayed. They did not live directly between the loosely attached bark and the compact log body, but in the soft woody material, together with Holotrochus species and earthworms. It is possible that the information "forest litter" means decayed wood in the forest litter and "mushrooms" means mushrooms at decaying wood. If this is true, it is probable that Osorius species mainly live in strongly decayed wood. The frequent catches by light traps or flight intercept traps indicate the species' high mobile flight activity which also may be due to the specific ecological conditions of their woody habitat. If the species need wood with specific decay conditions and rich in fungi, they would have to leave their habitat to seek other dead logs with the preferred decay status when conditions change.

The collecting status of most Osorius species in the Neotropics is extremely low and for many species there are very few specimens found. Nevertheless, a rough overview of their geographic distribution seems to be possible for a few species. If only species which are found at a greater number of locations are included, geographic segments may be differentiated. The Central 
American segment is rich in species and includes the following 7 species: O. canaliculatus, $O$. boops, $O$. confuses, $O$. costaricensis, $O$. dubius, O. morio, and $O$. puncticeps (Fig. 40, 42). Some of these species have only been found in northern Central America; others only in the southern parts. Another segment is represented by the species $O$. piceus, O. sahlbergi and $O$. ater which seem to be restricted to the South Brazilian coastal rainforest area (Fig. 41, 42). O. wasmanni might also be placed into this segment, but the number of records is still too low to confirm this thesis. A third segment comprises species of the South American Andean region (Fig. 41, 42). These are: O. alternans - from the southern Andean region from Bolivia to Ecuador - and $O$. intermedius and $O$. columbinus - from the northern region of Columbia and North Ecuador. The latter two species may reflect an endemic segment of the Chocó region at the northern Pacific coast. Compared to these three segments, two others may exist but are poorly represented. O. brasiliensis was found mainly in the north eastern part of South America, but also appear in eastern Brazil (Fig. 42). Unfortunately, many specimens of the species collected in Brazil originate from older collections without sufficiently defined geographic information. This is also true for $O$. stipes, which seems to represent a Central Amazonian segment.

\section{Acknowledgements}

I thank the following curators for their kind support, the loan of the material, and for individual specimens for my collection: Dr. L. Herman (AMNH), Dr. R. Booth (BMNH), Dr. A. Newton (FMNH), Dr. Y. Gerard (IRSNB), Dr. S. Ashe (KU), Dr. Bert Viklund (MS), Dr. M. Fikáček (NMP), Dr. J. Frisch (ZMHU), Dr. M. Baehr (ZSM), Dr. Juan Marquez Luna (UNAM), and Dr. A. Solodovnikov (ZMUK). I also thank Dr. V. Assing, Dr. J. Janák, Dr. M. Verhaagh, Dr. G. de Rougemont, and Dr. P. Hopp for putting their private collections to my disposal and endowing me with some specimens for my collection.

\section{References}

Bernhauer, M. 1904: Neue exotische Staphyliniden. - Verhandlungen der k. k. zoologisch-botanischen Gesellschaft in Wien 54: 4-24.

Bernhauer, M. 1908: Beitrag zur Staphylinidenfauna von Südamerika. - Archiv für Naturgeschichte 74: 283-372.

Bernhauer, M. 1920: Neue Arten der Staphylinienfauna von Südamerika, insbesondere aus den Gattungen Osorius und Megalops. - Neue Beiträge zur systematischen Insektenkunde 1: 137-139.

Bernhauer, M. 1942: Neue Staphyliniden aus Kostarika. - Zoologischer Anzeiger 138: 1-27.

BLACKWELDER, R. E. 1943: Monograph of the West Indian beetles of the family Staphylinidae. - Smithsonian Institution, United States National Museum, Bulletin 182: 1-658.

Blackwelder, R. E. 1952: The generic names of the family Staphylinidae. - Smithsonian Institution, United States National Museum, Bulletin 200: 1-483.

Coiffart, H. 1978: Deux genres d'Osoriinae (Coleoptera, Staphylinidae) de sud Portugal nouveaux pour la faune Européene. - Nouvelle evue d'Entomologie 8: 177-179.

Darlington, P. J. 1937: The West Indian species of Osorius (Coleoptera: Staphylinidae). - Bulletin of the Museum of Comparative Zoology 80: 283-301.

Erichson, W. F. 1839/1840: Genera et species Staphylinorum Insectorum Coleopterorum familiae. Berlin, Morin: $954 \mathrm{p}$.

ESRI 1999: Arc View GIS 3.2. Neuron Data Inc.

FAGEL, G. 1958: Mission de muséum dans les îles du golfe de Guinée. Entomologie. Sur quelques Osoriinae du golfe de de Guinée. - Revue Française d'Entomologie 25: 26-32. 
Fagel, G. 1959: Osoriinae (Coleoptera, Polyphaga) Fam. Staphylinidae. - In: Baert, P.; Demoulin, Denisoff I.; Martin, J.; Micha, M.; Noirfalise, A.; Schoemaker, P.; Troupin, G. \& Verschuren, J. (eds.) Parc national de la Gamba. Mission H. de Saeger. Vol. 12, Brussels, Hayez: 1-205.

Fauvel, A. 1903: Faune analytique des coléoptères de la Nouvelles-Calédonie. - Revue d'Entomologie 23: 43-70.

Guérin-Meneville, F. E. 1829: Iconographie de règne animal de G. Cuvier, ou représentation d'après nature de l'une des espèces les plus remarquables et souvent non encore figurées, de chaque genre d'animaux. Avec un texte descriptif mis au courant de la science. Ouvrage pouvant servir d'atlas a tous les traites de zoologie. - II. Planches des animaux invertébrés. Paris, Baillière.

Guérin-Meneville, F. E. 1844: Iconographie de règne animal de G. Cuvier, ou représentation d'après nature de l'une des espèces les plus remarquables et souvent non encore figurées, de chaque genre d'animaux. Avec un texte descriptif mis au courant de la science. Ouvrage pouvant servir d'atlas a tous les traites de zoologie. - Insectes. Paris, Baillière.

Herman, L. 2001: Catalogue of the Staphylinidae (Insecta: Coleoptera). 1758 to the end of the second millennium. II. Oxyteline group. - Bulletin of the American Museum of Natural History 265: 1067-1806.

Horn, W. \& Kahle, I. 1935: Über entomologische Sammlungen, Entomologen \& Entomo-Museologie (Ein Beitrag zur Geschichte der Entomologie). - Entomologische Beiträge 2-4: 1-388.

IrmLer, U. 1987: New Neotropical species of the genus Holotrochus and the new genus Mimotrochus (Coleoptera, Staphylinidae). - Entomologische Arbeiten Museum Frey 35/36: 81-109.

Latreille, P. A. 1832: Considérations sur les insects coléoptères de la tribu des denticrures, familie des brachélytres. - Nouvelle Annales du Museum d'Histoire Naturelles 1: 77-92.

Notman, H. 1925: A synoptic review of the beetles of the tribe Osoriini from the Western Proceedings of the United States National Museum 67: 1-26.

Perty, J. A. M. 1830: Insecta Brasiliensia. - In: Spix, J. \& Martius, C. (eds.) Delectus animalium articulatorum, quae in itinere per Brasiliam annis MDCCCXVII - MDCCCXX jussu et auspiciis Maximiliani Josephi I. - Bavariae regis augustissimi peracto: 1-60.

Schubert, K. 1911: Neue exotische Staphyliniden. (Coleoptera). - Deutsche Entomologische Zeitschrift 1911: 1-39.

Sharp, D. 1876: Contributions to the Staphylinidae of the Amazon valley. - Transactions of the Entomological Society London: 34-424.

Sharp, D. 1887: Fam. Staphylinidae. - In: Biologia Centrali-Americana. Insecta, Coleoptera. Vol. 1 (2). Taylor \& Francis, London: pp. 145-824, pls. 5-19.

Solsky, S. M. 1870: Staphylins de l'Amérique méridional et du Mexique. - Bulletin de la Société Impériale des Naturalistes de Moscou 42: 257-267.

\section{Author's address:}

Prof. Dr. UlRich IrmLER

Institut für Ökosystemforschung

Abteilung Angewandte Ökologie

Universität, Olshausenstrasse 40

24098 Kiel, Germany

email: uirmler@ecology.uni-kiel.de

\section{Subject Editor:}

Dr. L. Zerche 

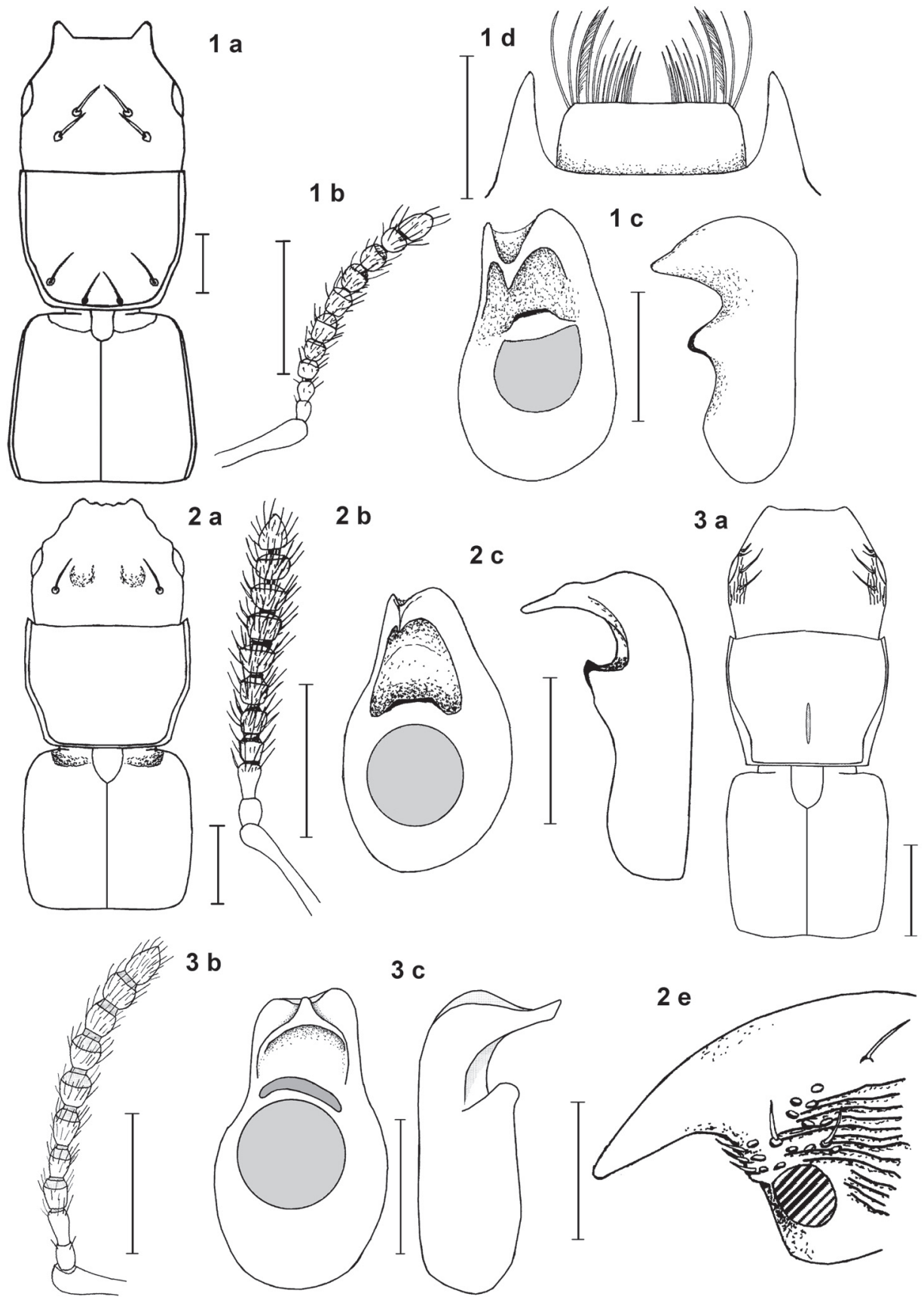

Fig. 1: Osorius ater. - Fig. 2: O. stipes. - Fig. 3: O. alternans (a: front body, b: antenna, c: aedeagus in ventral and lateral aspect, d: clypeus with labrum, e: head in lateral aspect; scale bar a, b: $1 \mathrm{~mm}, \mathrm{c}, \mathrm{d}$, e: $0.5 \mathrm{~mm}$ ). 


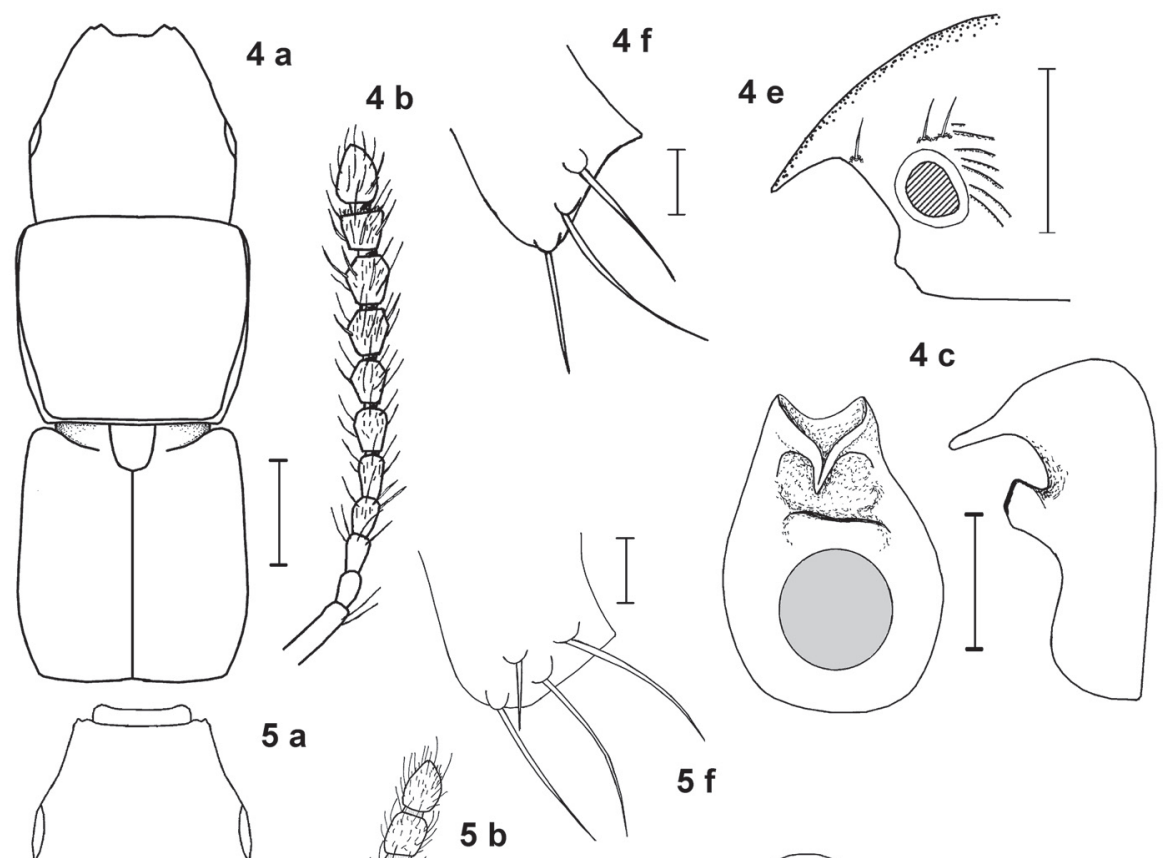



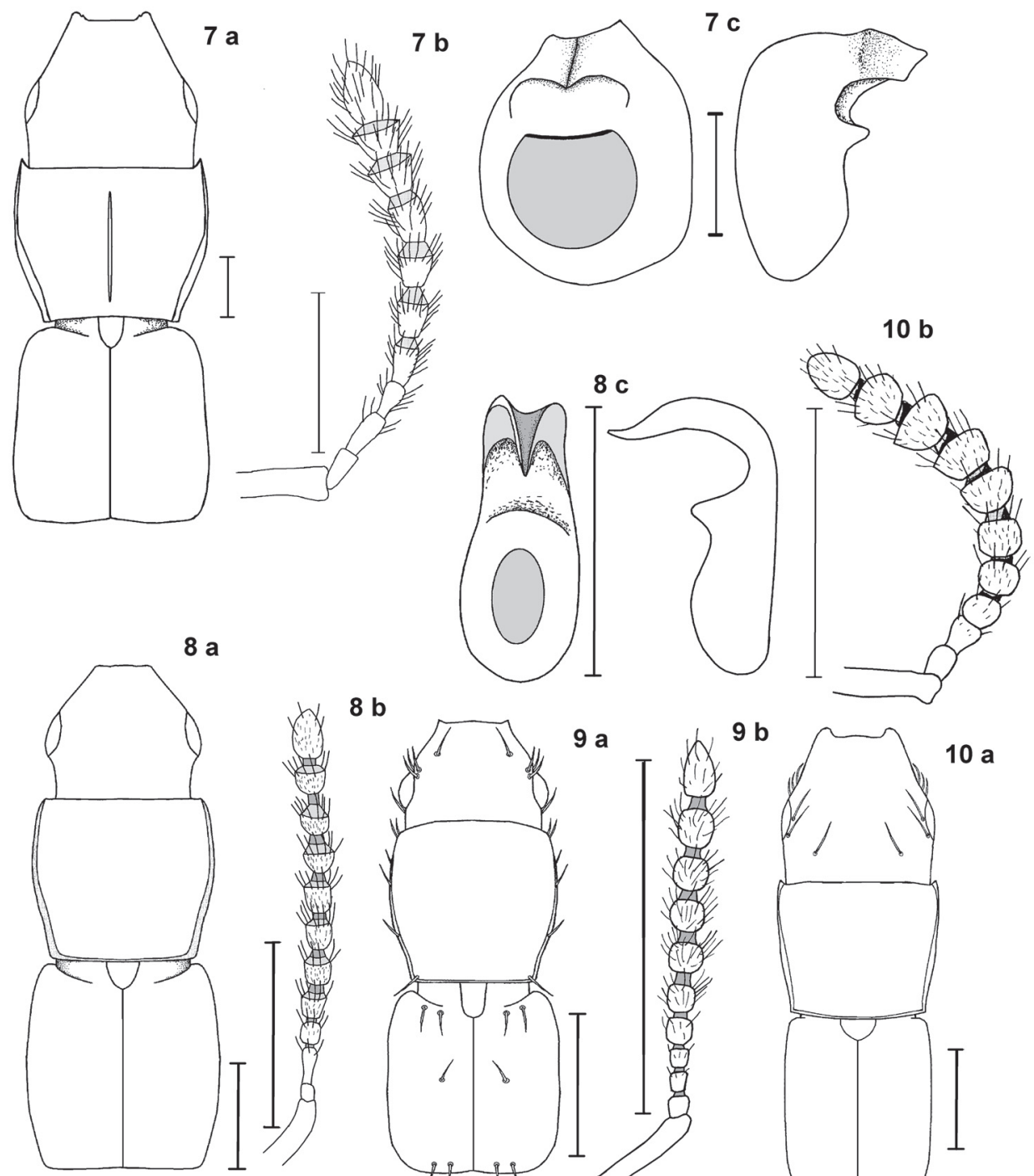

8 b
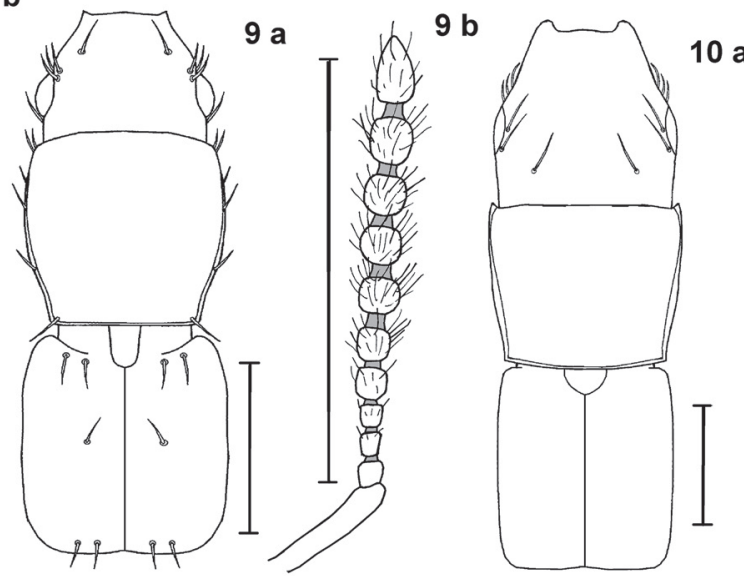

Fig. 7: Osorius canaliculatus. - Fig. 8: O. boops. - Fig. 9: O. affinis. - Fig. 10: O. granulatus (a: front body, b: antenna, c: aedeagus in ventral and lateral aspect scale bar: a - b: $1 \mathrm{~mm}, \mathrm{c:} 0.1 \mathrm{~mm}$ ). 


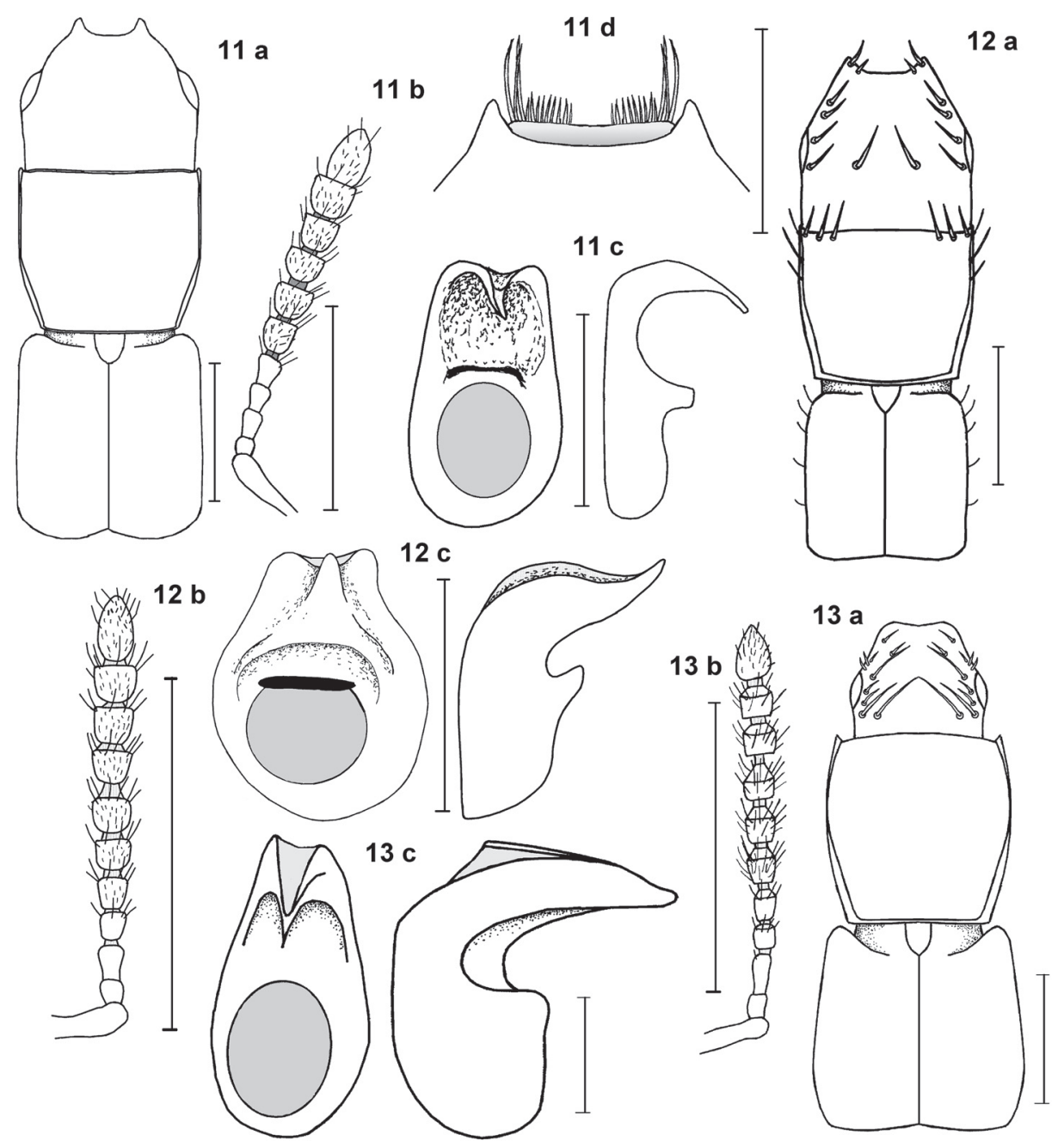

Fig. 11: Osorius dentatus. - Fig. 12: O. costaricensis. - Fig. 13: O. verhaagi (a: front body, b: antenna, c: aedeagus in ventral and lateral aspect; scale bar: a, b: $1 \mathrm{~mm}, \mathrm{c}, \mathrm{d}: 0.5 \mathrm{~mm}$ ). 


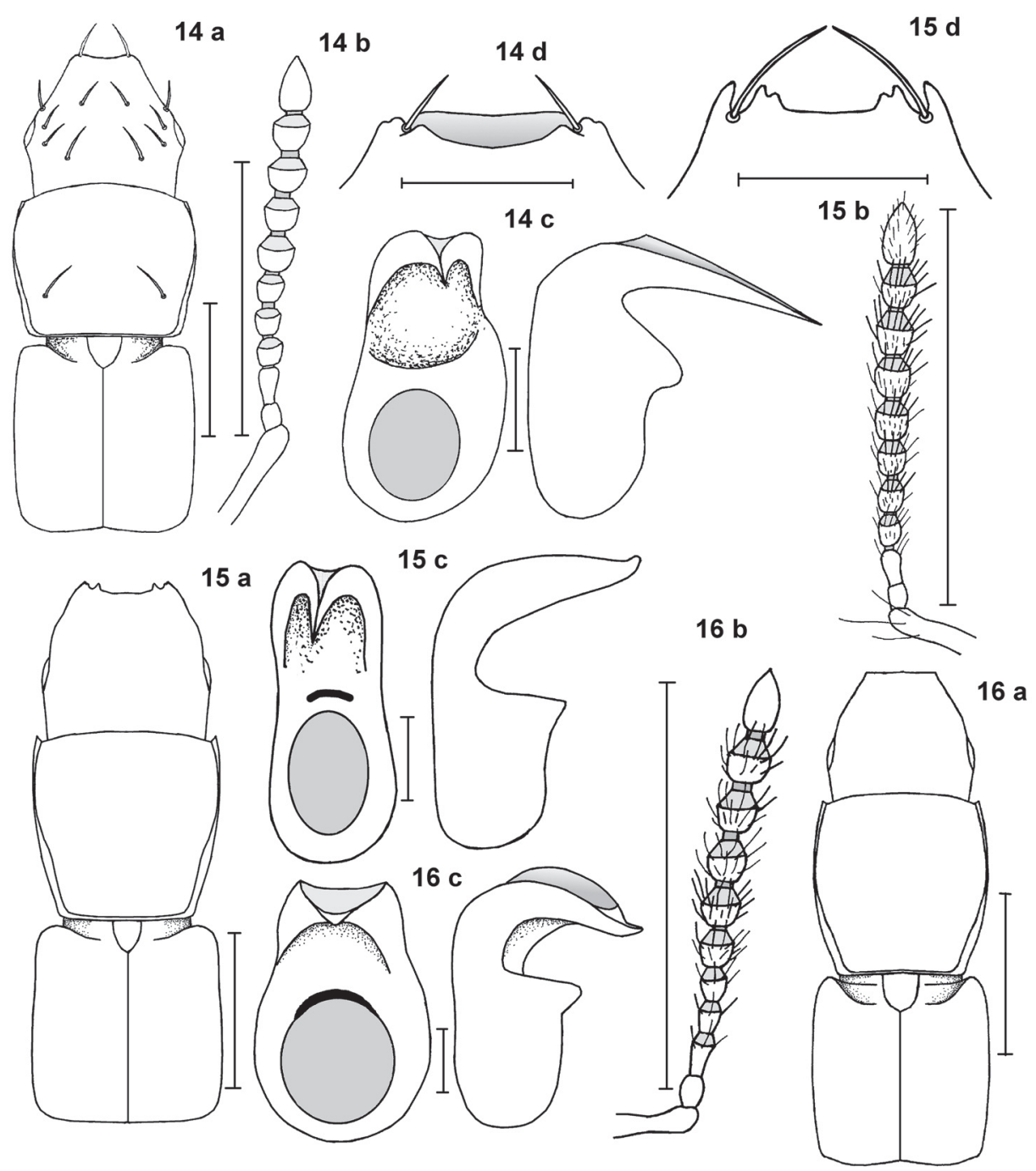

Fig. 14: Osorius paganus. - Fig. 15: O. venezuelanus. - Fig. 16: Osorius pusillus (a: front body, b: antenna, c: aedeagus in ventral and lateral aspect, d: clypeus with labrum; scale bar: a, b: $1 \mathrm{~mm}, \mathrm{c}: 0.2 \mathrm{~mm}$, d: $0,5 \mathrm{~mm})$. 


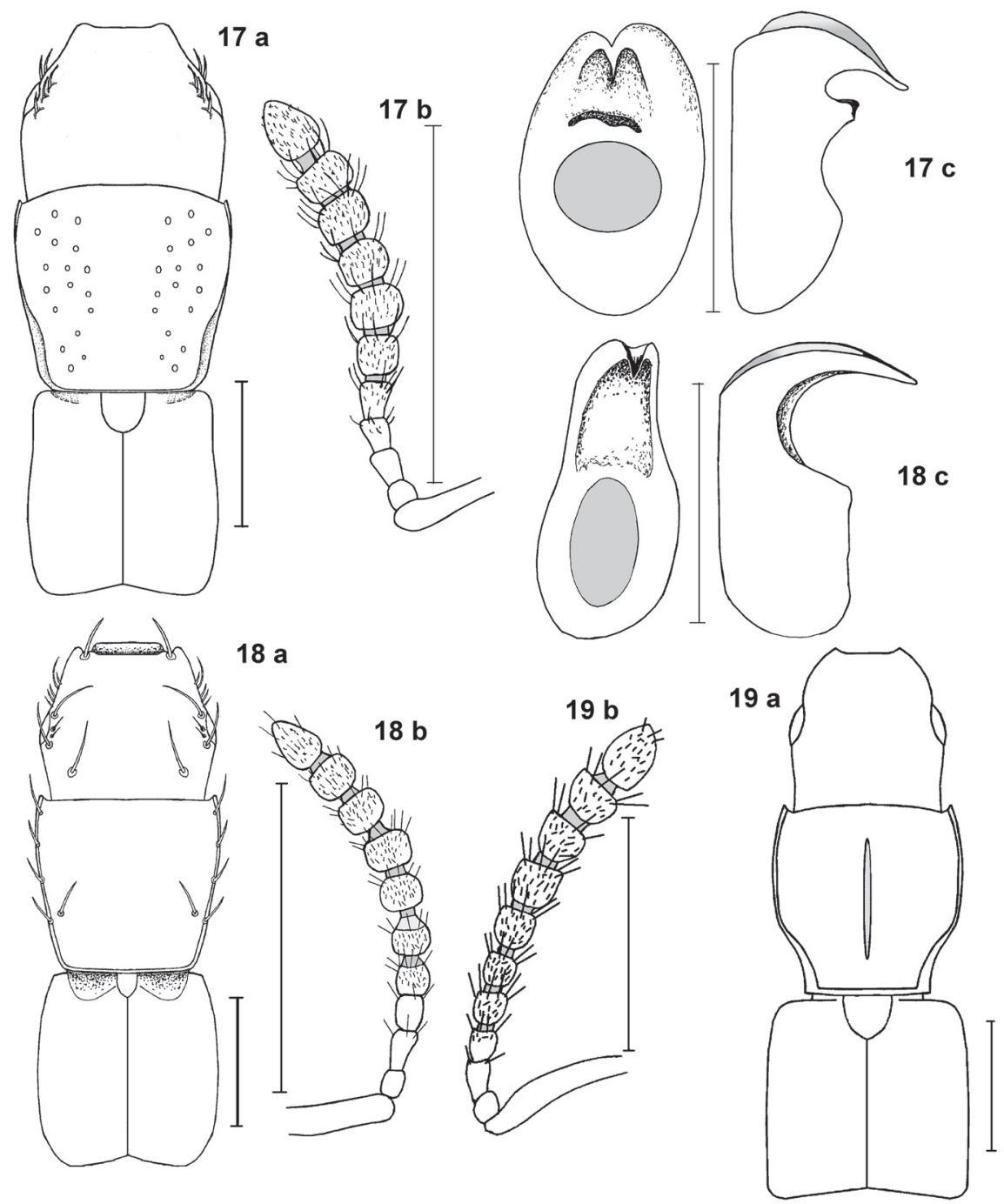

Fig. 17: O. laevicollis. - Fig. 18: O. sublaevis. - Fig. 19: Osorius sinuatocollis (a: front body, b: antenna, c: aedeagus in ventral and lateral aspect; scale bar: a, b: $1 \mathrm{~mm}, \mathrm{c:} 0.5 \mathrm{~mm}$ ). 


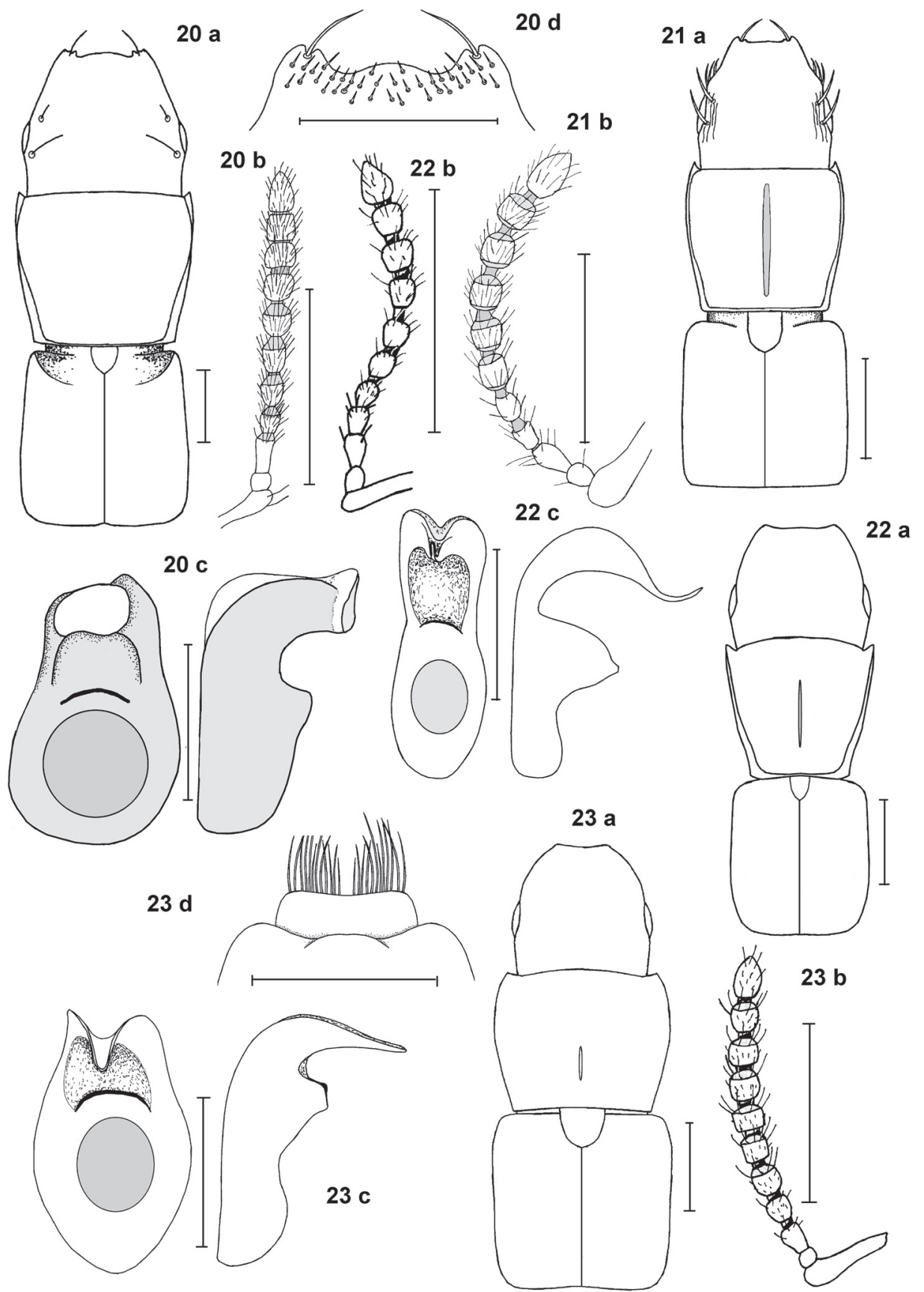

Fig. 20: O. ashei. - Fig. 21: O. laevigatulus. - Fig. 22: O. wasmanni. - Fig. 23: Osorius peruvianus (a: front body, b: antenna, c: aedeagus in ventral and lateral aspect, d: clypeus; scale bar: a, b, d: $1 \mathrm{~mm}, \mathrm{c:} 0.5 \mathrm{~mm}$ ). 

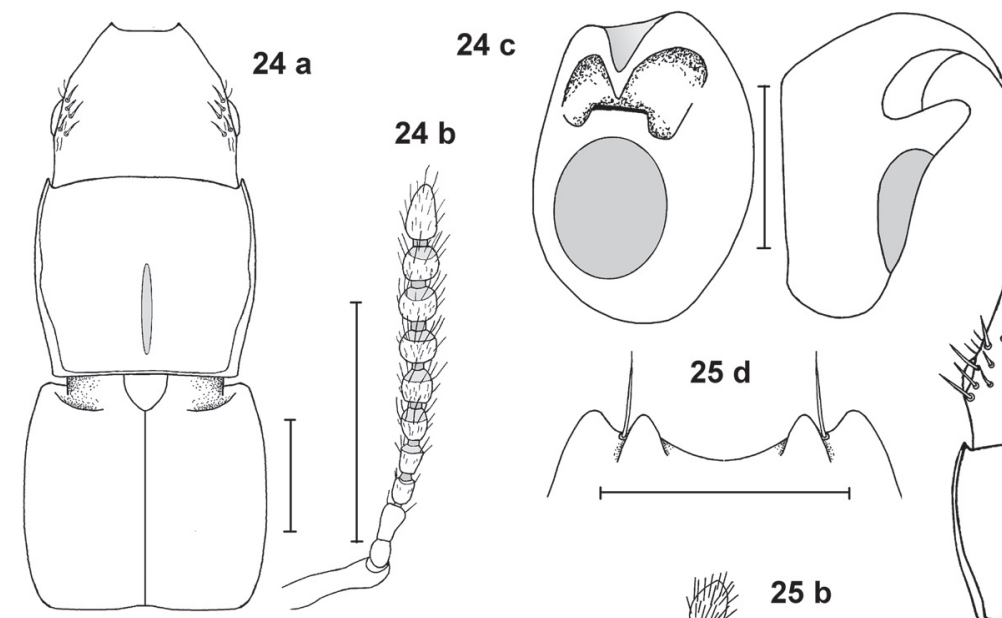

25 a
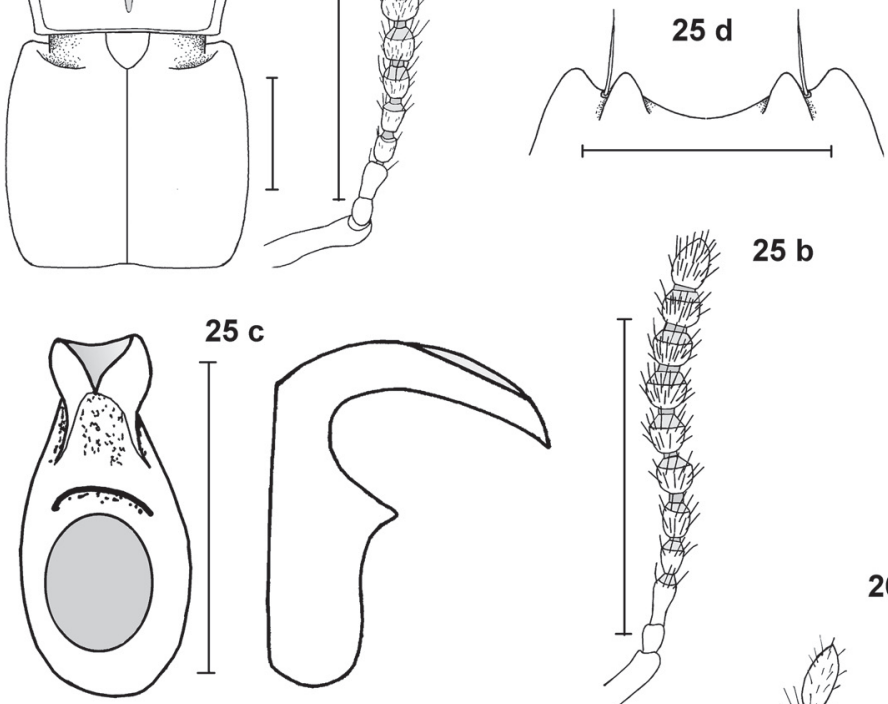

$25 \mathrm{~b}$
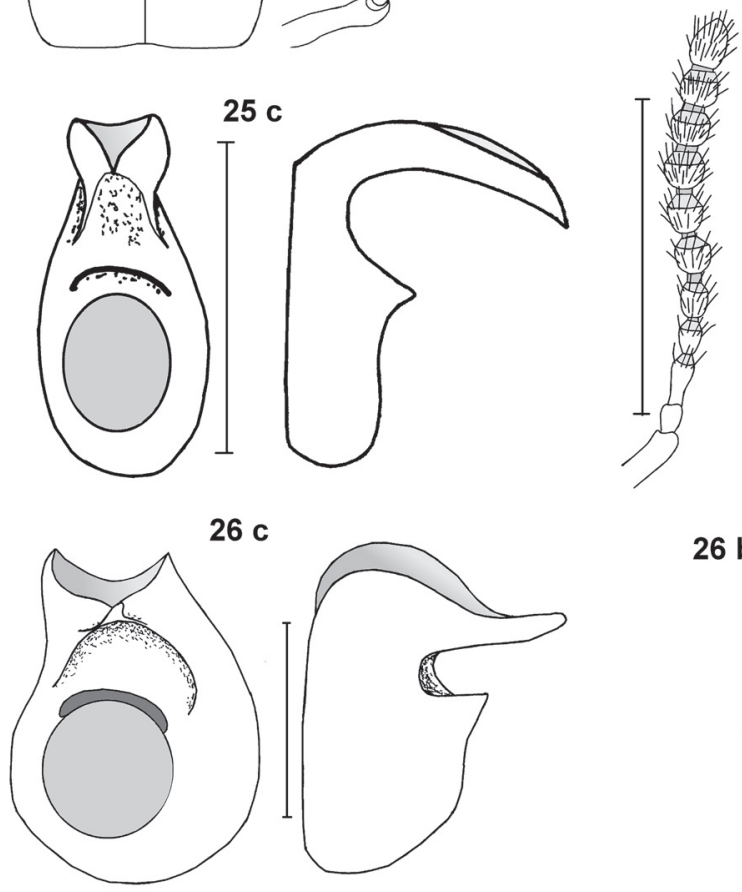

$26 \mathrm{~b}$

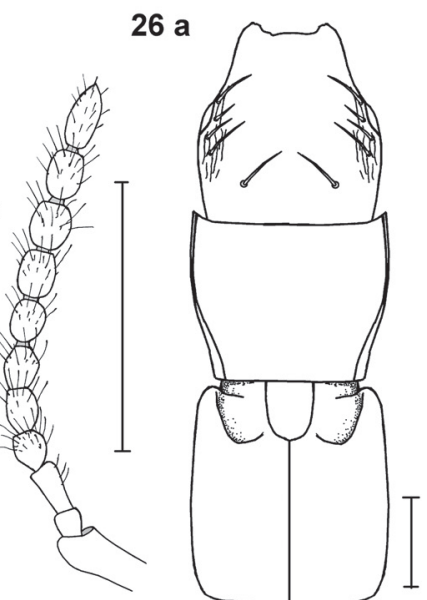

Fig. 24: O. integer. - Fig. 25: O. tschirnhaus. - Fig. 26: O. guianensis (a: front body, b: antenna, c: aedeagus in ventral and lateral aspect, d: clypeus; scale bar: a, b, d: $1 \mathrm{~mm}, \mathrm{c}: 0.5 \mathrm{~mm}$ ). 

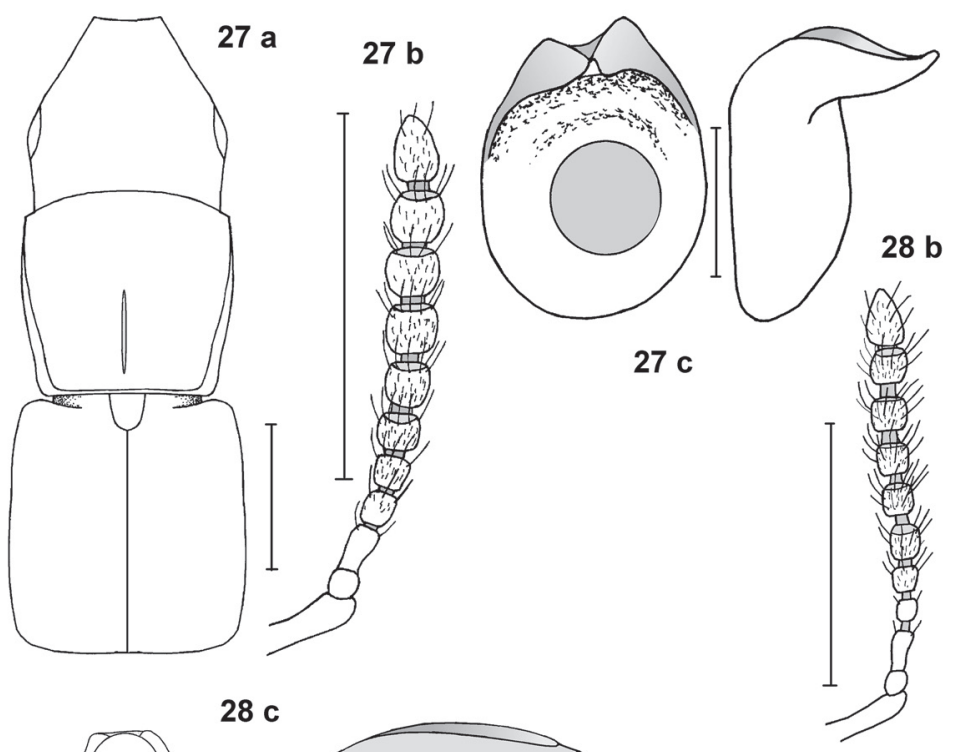

28 a
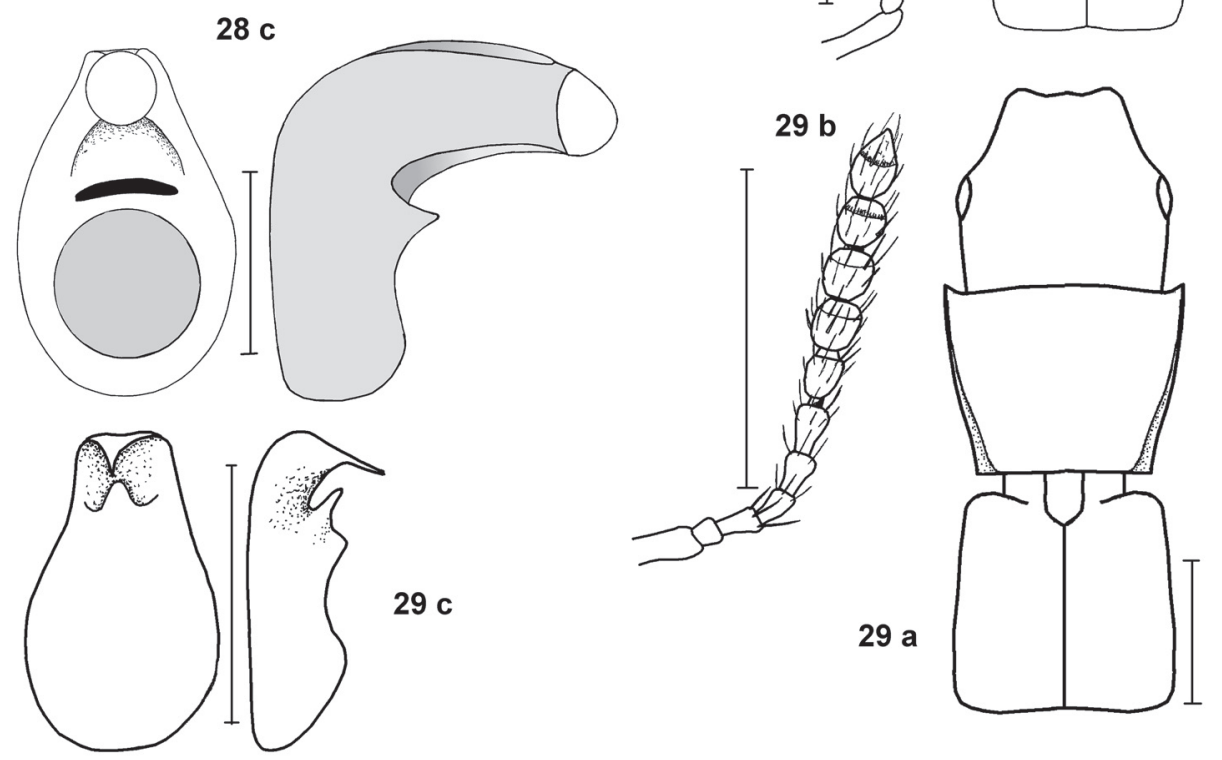

Fig. 27: O. dubius. - Fig. 28: O. morio. - Fig. 29: O. piceus (a: front body, b: antenna, c: aedeagus in ventral and lateral aspect; scale bar: a, b: $1 \mathrm{~mm}, \mathrm{c}: 0.5 \mathrm{~mm}$ ). 


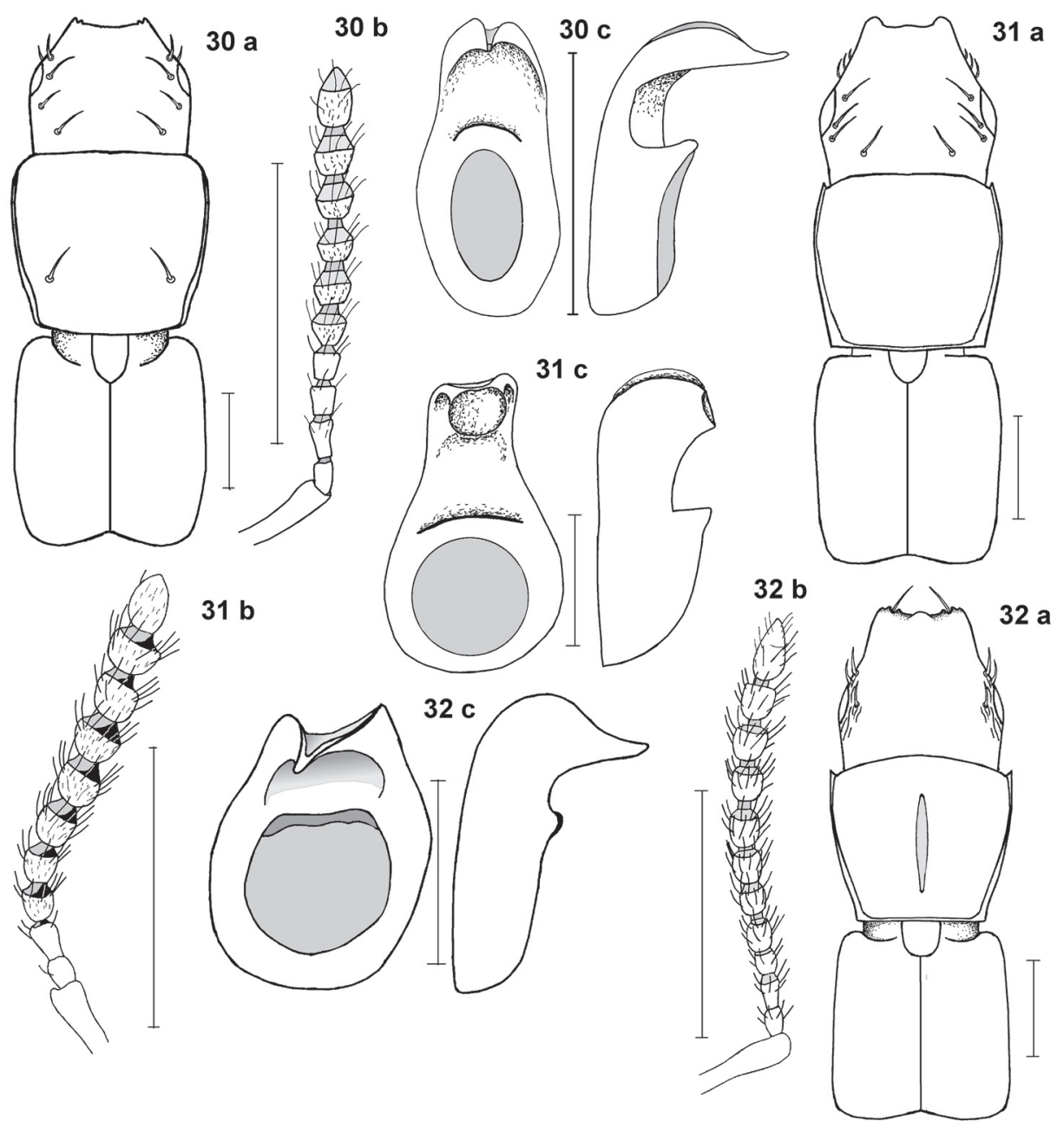

Fig. 30: Osorius continentalus. - Fig. 31: O. sablbergi. - Fig. 32: O. confusus (a: front body, b: antenna, c: aedeagus in ventral and lateral aspect; scale bar: a, b: $1 \mathrm{~mm}, \mathrm{c:} 0.5 \mathrm{~mm}$ ). 


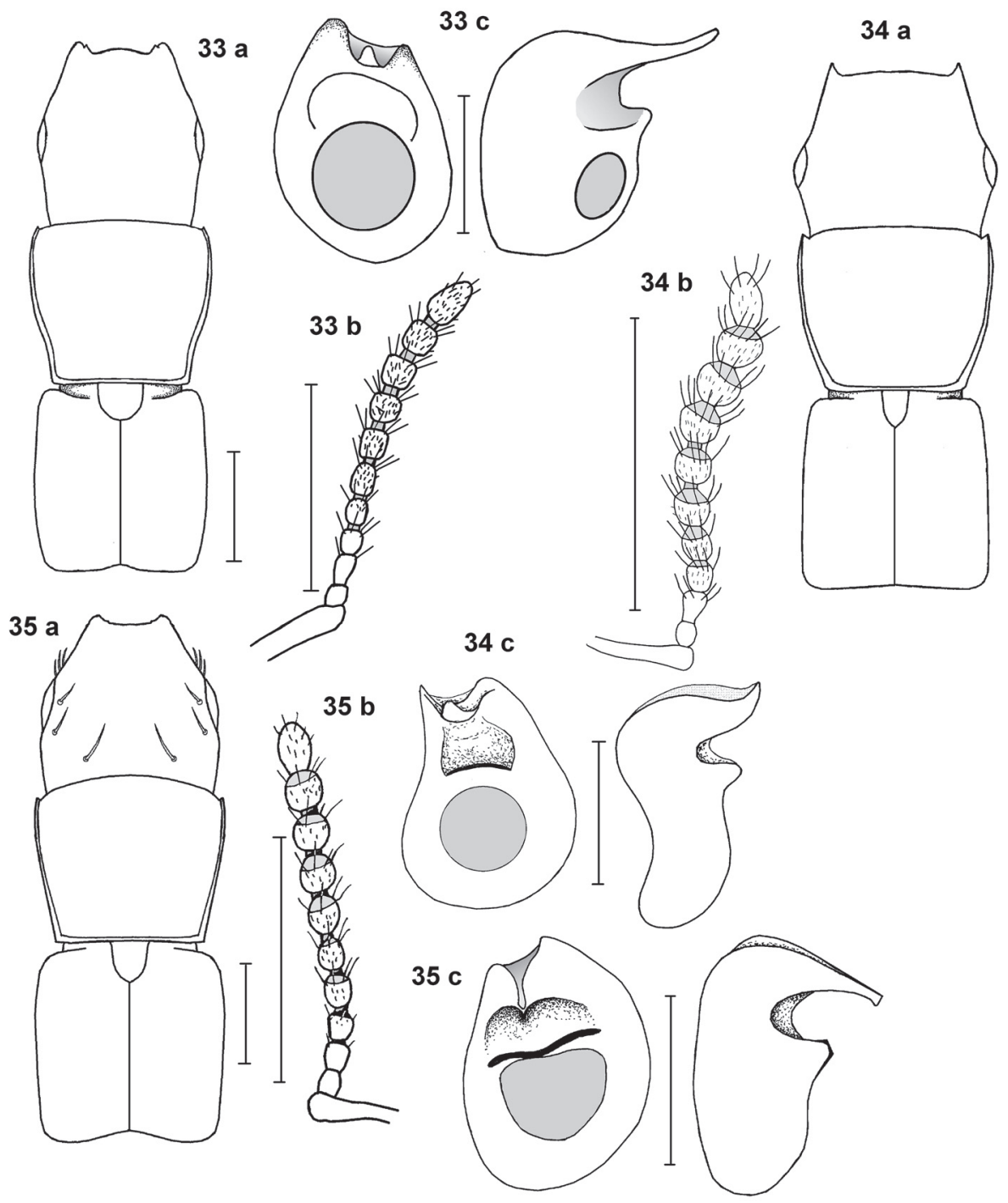

Fig. 33: Osorius puncticeps. - Fig. 34: O. propinquus. - Fig. 35: O. nitens (a: front body, b: antenna, c: aedeagus in ventral and lateral aspect; scale bar: a, b: $1 \mathrm{~mm}, \mathrm{c}: 0.5 \mathrm{~mm}$ ). 

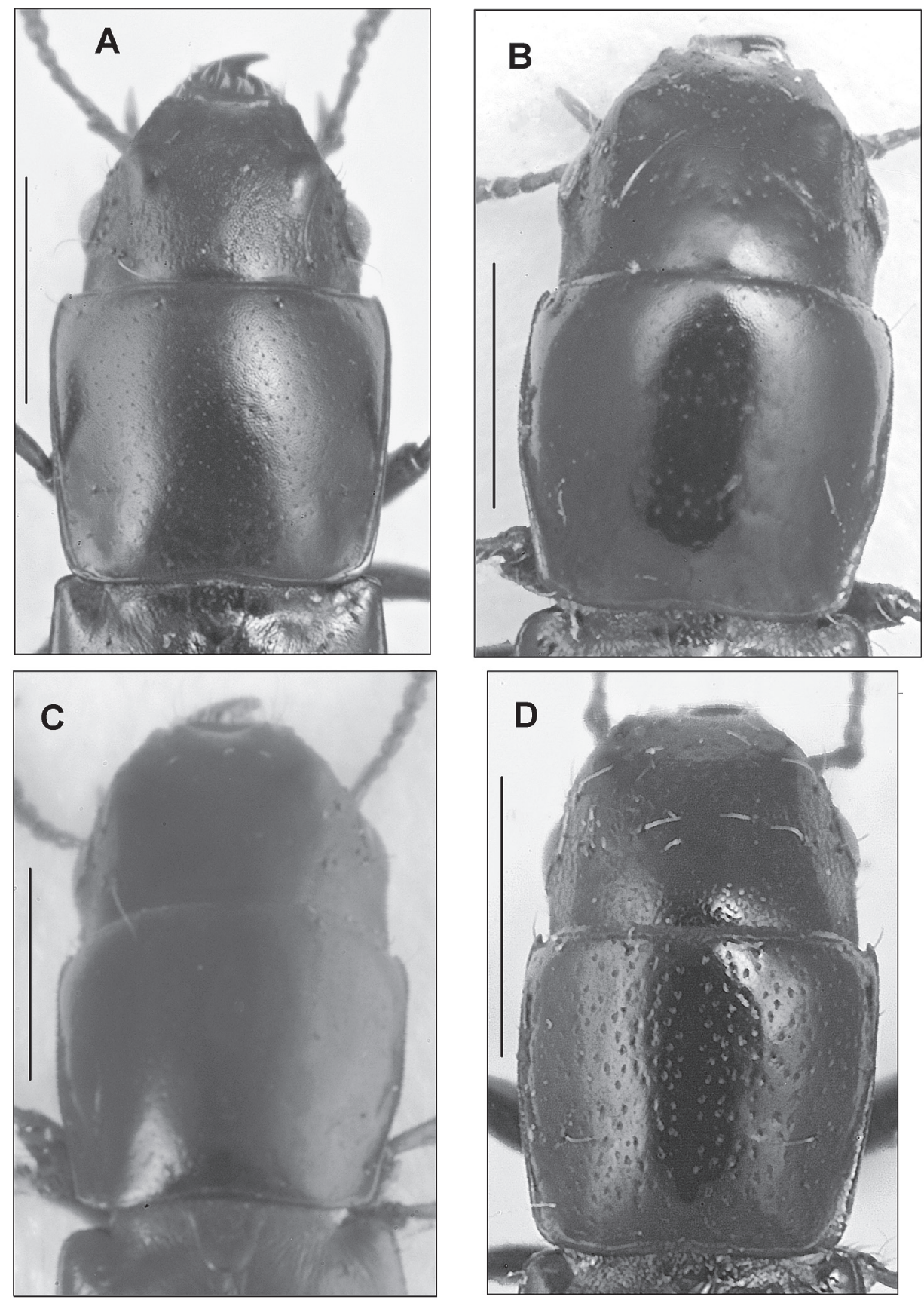

Fig. 36: Head and pronotum of Osorius verhaaghi (A), O. paganus (B), O. venezuelanus (C), O. pusillus (D) (scale bar: $1 \mathrm{~mm}$ ). 

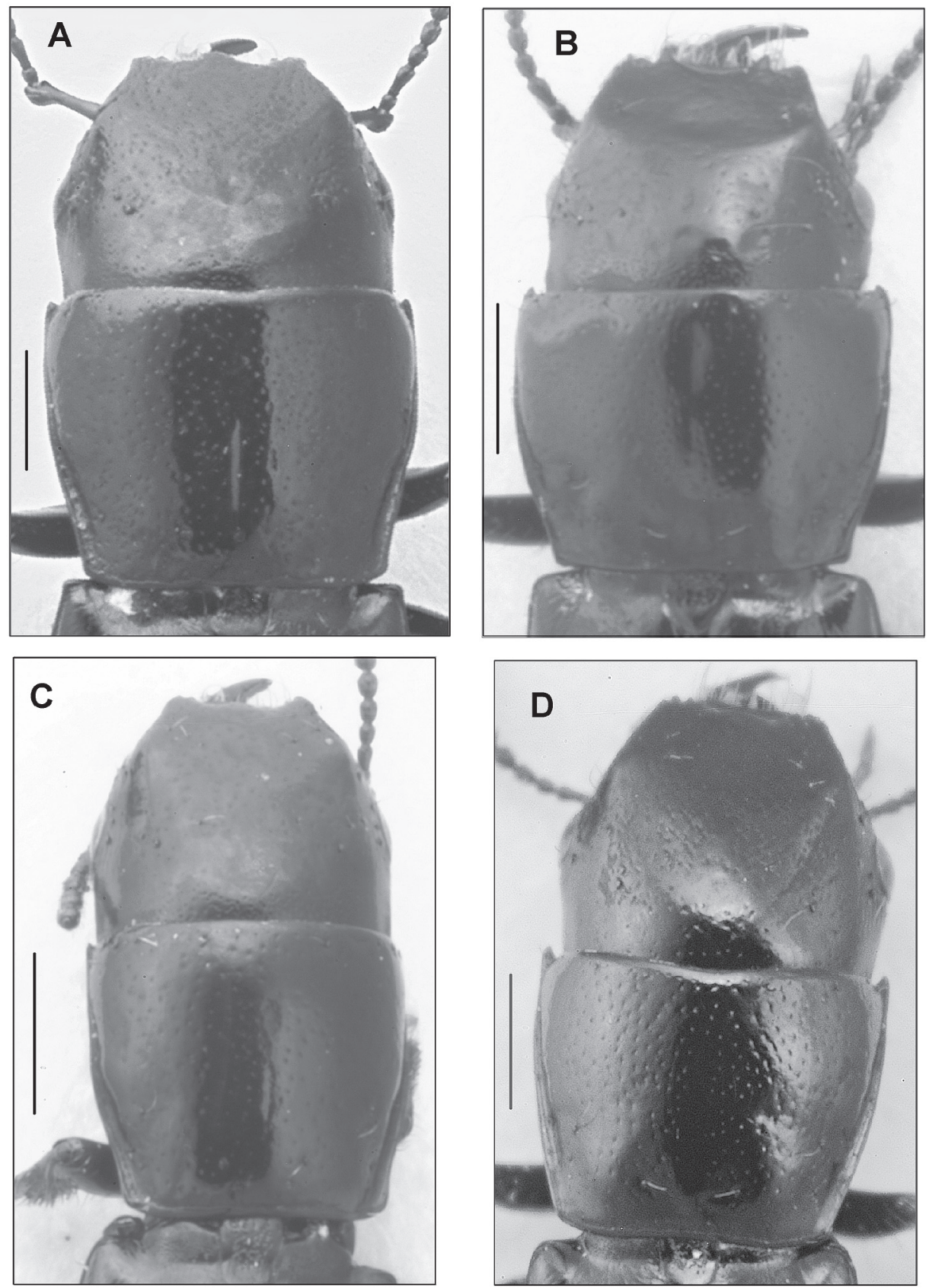

Fig. 37: Head and pronotum of $O$. ashei (A), O. tschirnhausi (B), O. continentalus (C), O. guianensis (D) (scale bar: $1 \mathrm{~mm}$ ). 

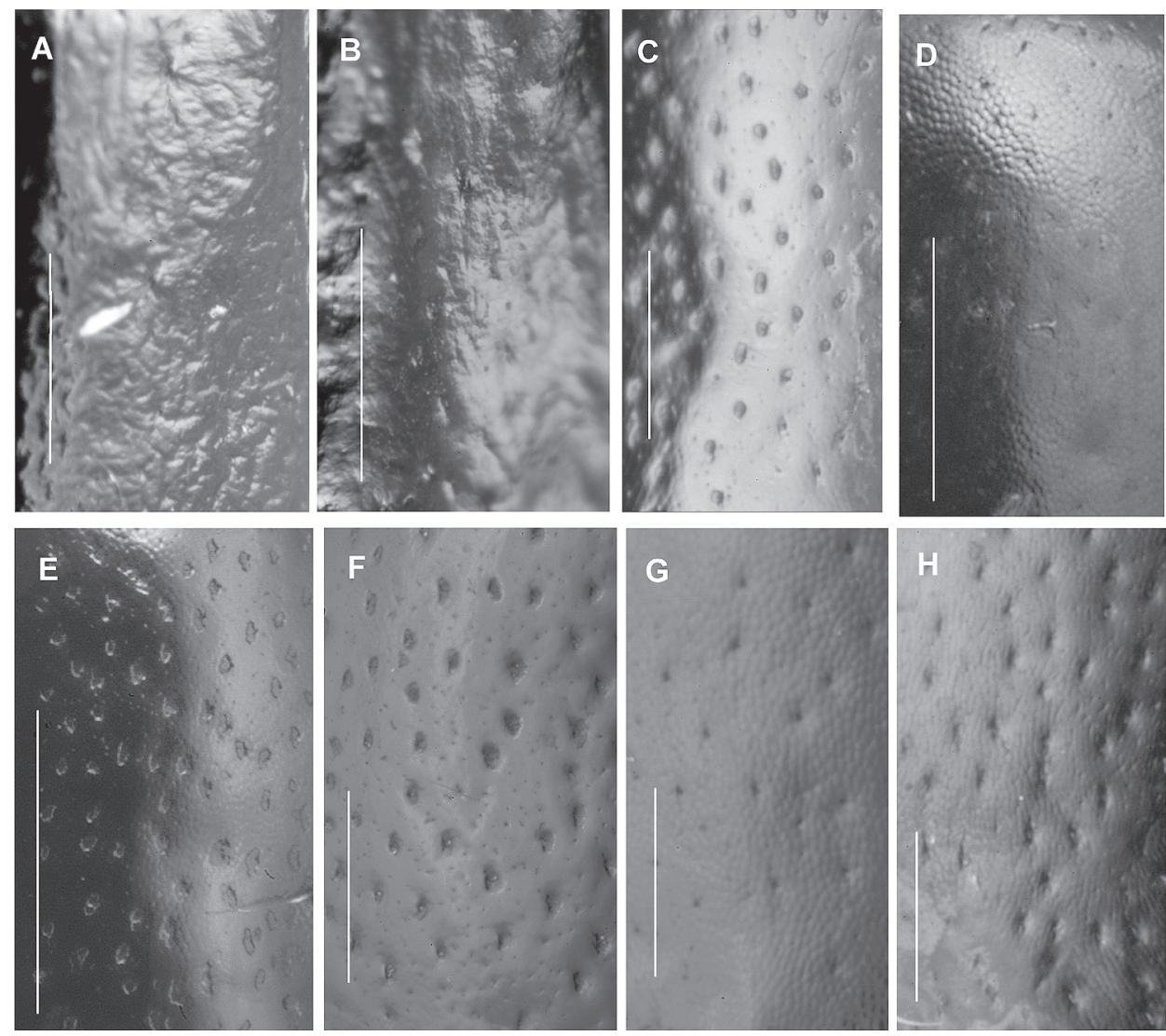

Fig. 38: Surface of elytra of Osorius columbinus (A), O. brasiliensis (B), and surface of pronotum of O.dentatus $(\mathrm{C})$, O. paganus $(\mathrm{D})$, O. pusillus $(\mathrm{E})$, O. peruvianus $(\mathrm{F})$, O.dubius $(\mathrm{G})$, O. confusus $(\mathrm{H})$ (scale bar: $0.5 \mathrm{~mm}$ ). 

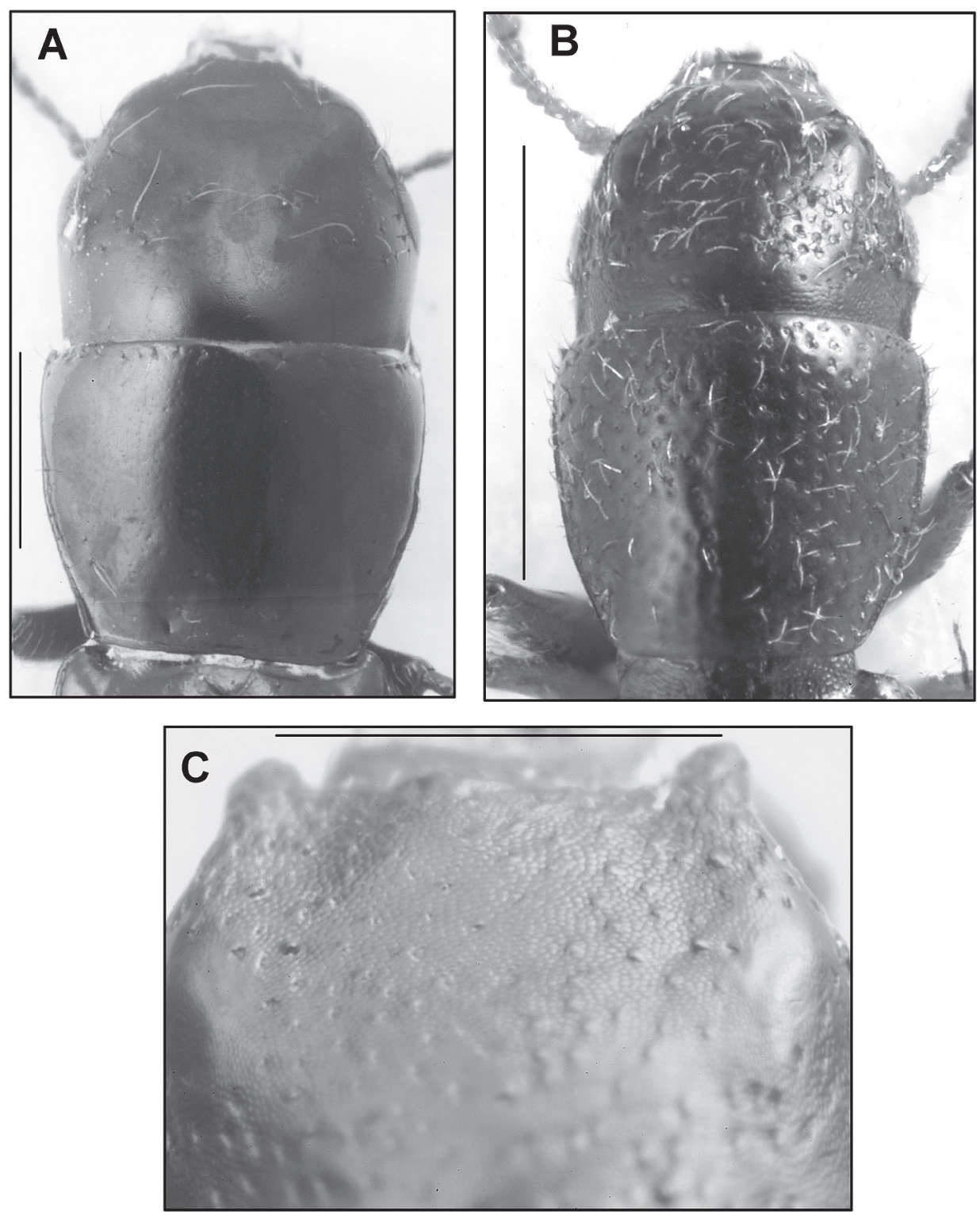

Fig. 39: Pronotum of Antillosorius daemon (A), pronotum of Osoriellus eggersi (B), and fore head of Osorius granulatus $(\mathrm{C})$ (scale bar $1 \mathrm{~mm}$ ). 


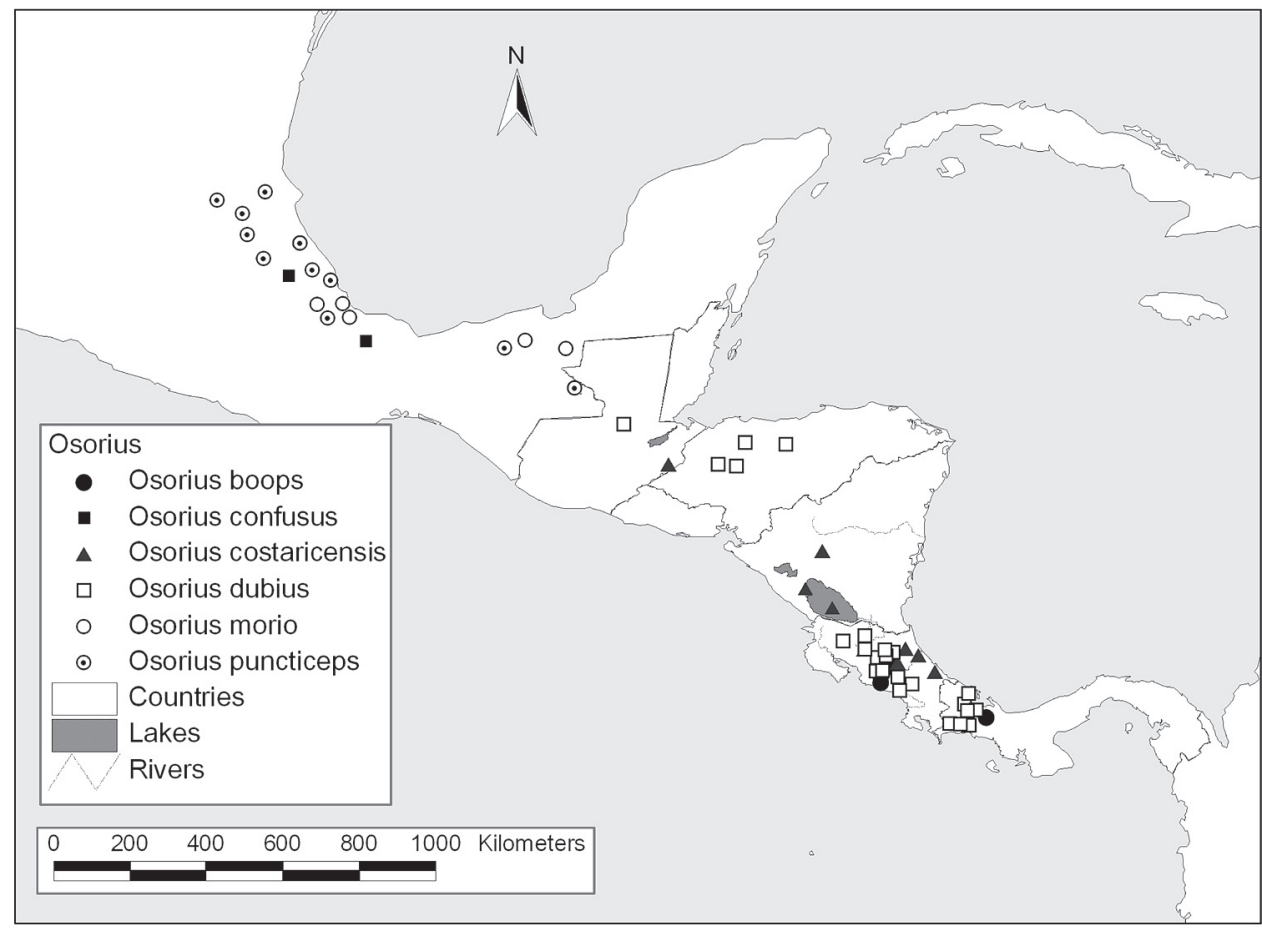

Fig. 40: Distribution of Central American Osorius species.

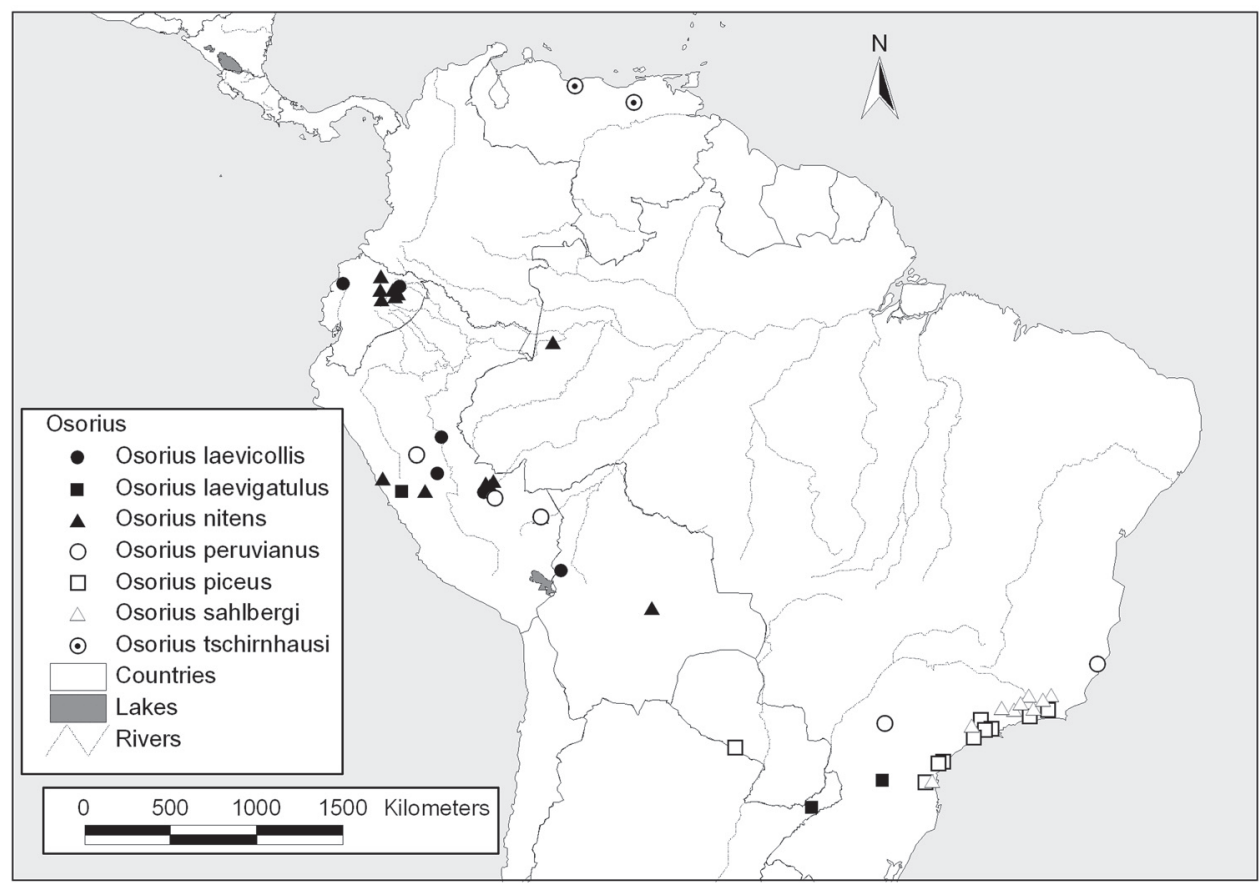

Fig. 41: Distribution of Osorius species with Andean and South Brazilian distribution. 


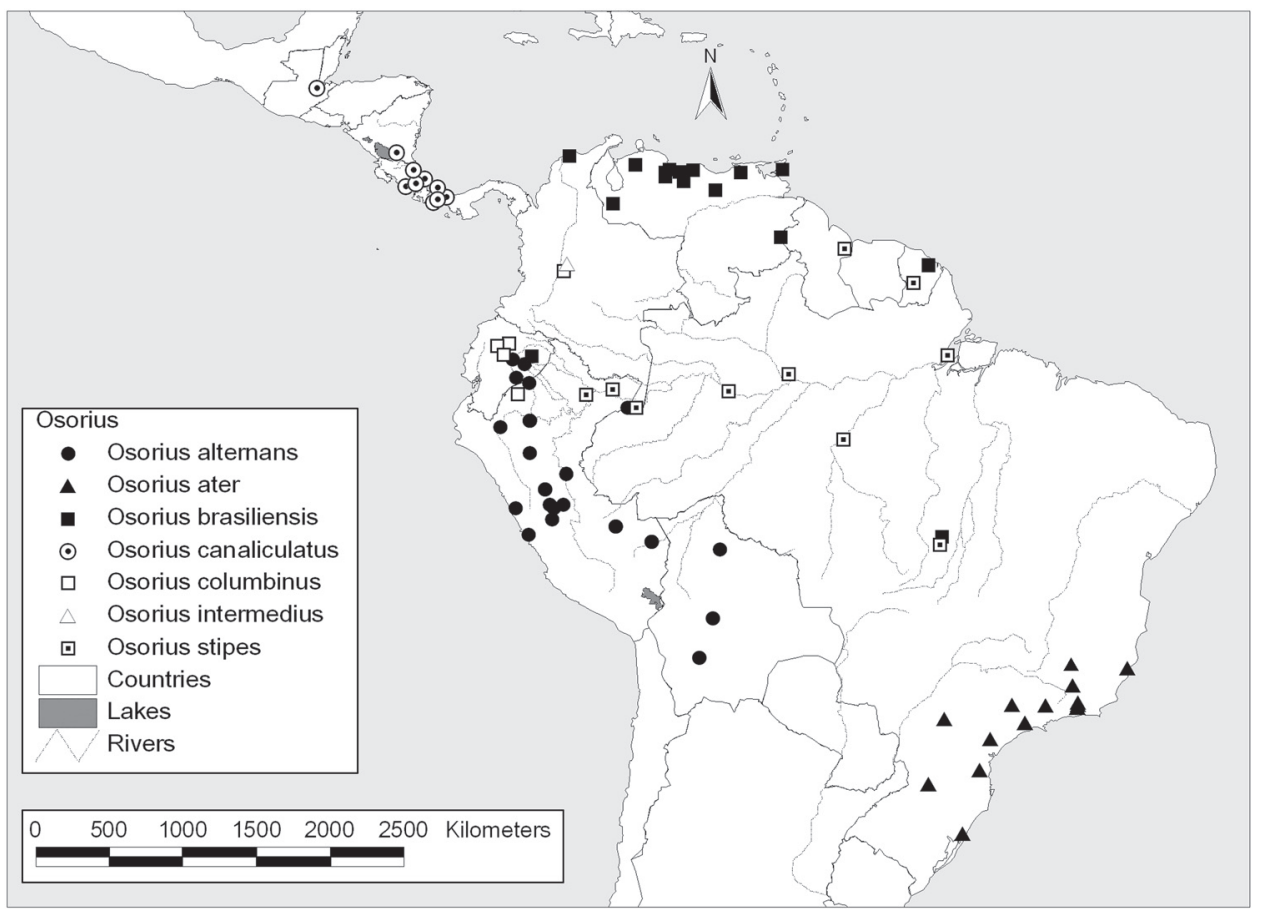

Fig. 42: Distribution of the large Osorius species. 